A. Information Category

\begin{tabular}{ll}
$\square$ Aostract & $\square$ Joumal Article \\
$\square$ Summary & $\square$ Intemet \\
$\square$ Visual Aid & $\square$ Software \\
$\square$ Full Paper & $\square$ Report \\
$凶$ Other & \\
\hline
\end{tabular}

B. Document Number HNF- 4293

C. Titie

Project Management Plan for Low-Level Mixed Waste and

Greater-Than-Category 3 waste Per Tri-Party Agreement M-91-10

D. Intemet Address

E. Required Information

1. Is documben potgntially classified? () No OYes (MANDATORY)

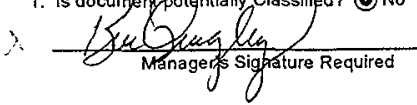

If Yes

$$
\text { ADC Signature Required }
$$

(O) OYes Classified
2. Internal Review Required?
If Yes, Document Signatures Below
ONo OYes

Counsel

Program

3. References in the Information are Applied Technology (2) No OYes Export Controlled Information

Ono Ores

F. Complete for a Journal Article

1. Title of Journal

G. Complete for a Presentation
4. Does Intormation contain the Following: (MANDATORY) If "Yos", Disclosure No.:

b. Information Received in Confidence, Such as Proprietary and/or Inventions?

ONo OYes If "Yes", Affix Appropriate Legendis/Notices.
c. Copyrights?
ONo
OYes
If "Yes", Attach Permission.
d. Trademarks?
ONo OYes
If "Yos", Identify in Document.

5. Is Information requiring submission to OSTI? $O$ No $O$ Yes If Yes $U C$ - _

6. Release Level?

7. Charge code 104241 BA 10 101634 Thoo 144 Task35 $103153=14130$ a. New or Novel (Patentable) Subject Matter? (O) No OYes

1. Title for Conference or Meeting

2. Group Sponsoring

a. Date of Conference

5. Will Information be Published in Proceedings? $O$ No $O$ Yes

4. City/State

6. Will Material be Handed Out? $\bigcirc$ No $O$ Yes

H. Authol/Requestor

tarbi

(Print and Sign)

1. Reviewers

General Counsel

Office of External Affairs

DOE-RL

Other

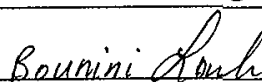

Responsible Manager

* KEN QueGLEY (Print and Sign).
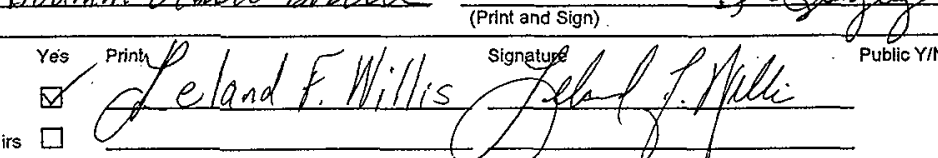

Signatuse
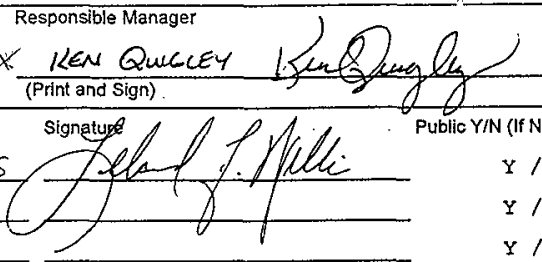

ublic $Y / N$ (If $N$, complete $J)$

Other

Q IL MUORE
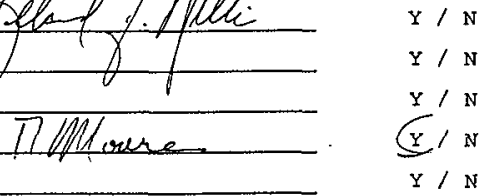

J. If Information Includes Sensitive information and is not to be released to the Public indicate category below.
$\square$ Applied Technology
$\square$ Protected CRADA
$\square$ PersonallPrivate
$\square$ Export Controlled
$\square$ Proprietary
$\square$ Procurement-Sensitive
$\square$ Business-Sensitive
$\square$ Patentable
$\square$ Predecisional
$\square$ Other (specify)

$\square$ UCN1

K. If Additional Comments, Please Attach Separate Sheet

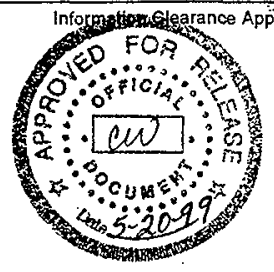




\section{Project Management Plan for Low-Level Mixed Waste and Greater-Than-Category 3 Waste per Tri-Party Agreement M-91-10}

Date Published

May 1999

Prepared by

Larbi Bounini

Waste Management Federal Services of Hanford, Inc.

Prepared for the U.S. Department of Energy

FLUOR DANIEL HANFORD, INC.

Richland, Washington

Hanford Management and Integration Contractor for the

U.S. Department of Energy under Contract DE-ACO6-96RL13200

Approved for Public Release; Further Dissemination Unlimited 


\section{RELEASE AUTHORIZATION}

Document Number:

Document

Title:
HNF-4293, Rev. 0

Project Management Plan for Low-Level Mixed Waste and Greater-Than-Category 3 Waste Per Tri-Party

Agreement M-91-10

\section{This document, reviewed in accordance with DOE Order 241.1, "Scientific and Technical Information Management," and DOE G 241.1-1, "Guide to the Management of Scientific and Technical Information," does not contain classified or sensitive unclassified information and is:}

\section{APPROVED FOR PUBLIC RELEASE}

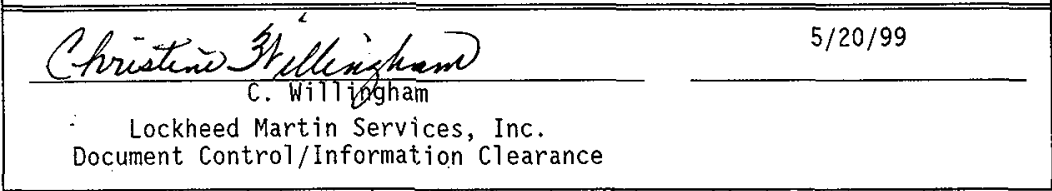

Reviewed for Applied Technology, Business Sensitive, Classified, Copyrighted, Export Controlted, Patent, Personal/Private, Proprietary, Protected CRADA, Trademark, Unclassified Controlled Nuclear Information.

LEGAL DISCLAIMER. This report was prepared as an account of work sponsored by an agency of the United States Government. Neither the United States Government nor any agency thereof, not any of their employees, nor any of their contractors, subcontractors or their employees, makes any warranty, express or implied, or assumes any legal liability or responsibility for the accuracy, completeness, or any third party's use or the results of such use of any information, apparatus, product, or process disclosed, or represents that its use would not infringe privately owned rights. Reference herein to any specific commercial product, process, or service by trade name, trademark, manufacturer, or otherwise, does not necessarily constitute or imply $i$ ts endorsement, recommendation, or favoring by the United states Goverrment or any agency thereof or its contractors or subcontractors. The views and opinions of authors expressed herein do not necessarily state or reflect those of the United States Government or any agency thereof. This report has been reproduced from the best available copy. Printed in the United States of America. 


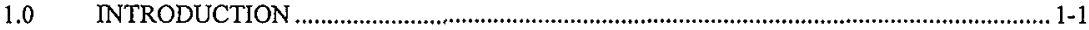

$1.1 \quad$ PROJECT MANAGEMENT PLAN OBJECTIVES .......................................................... $1-1$

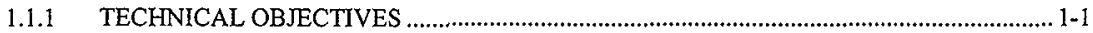

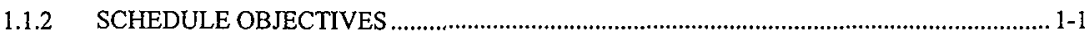

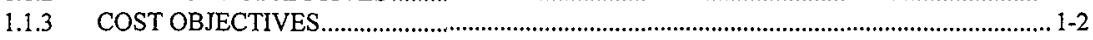

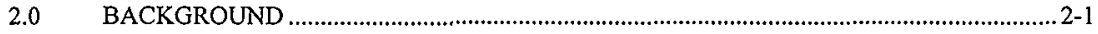

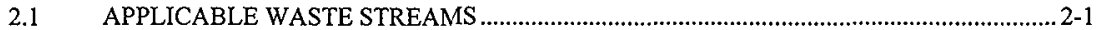

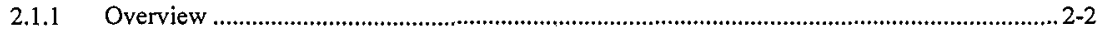

2.1.2 Applicable Waste Stream Volumes ........................................................................................ 2-3

2.1.2.1 Large Container Contact-Handled Low-Level Mixed Waste Volumes ....................................2-4

2.1.2.2 Remote-Handled Low-Level Mixed Waste Volumes ..............................................................2 2-4

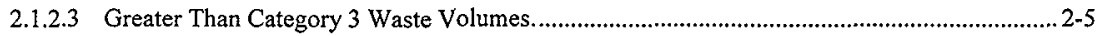

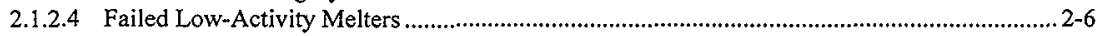

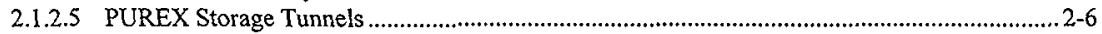

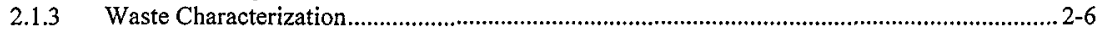

$2.2 \quad$ WASTE STREAM STABILITY AND CONTAMINANT MIGRATION_.............................2-7

2.2.1 Radiological Stability of Waste Forms .................................................................................2 2-7

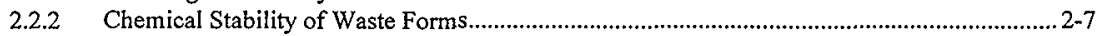

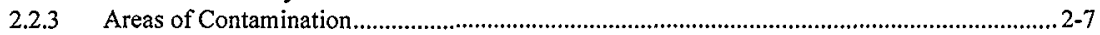

2.3 EXISTING TREATMENT CAPACITY AND OPTIONS CONSIDERED ...........................2-8

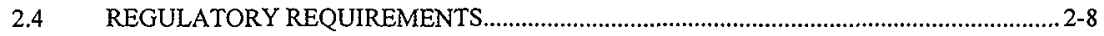

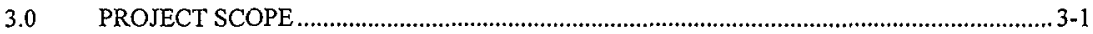

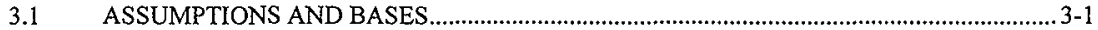

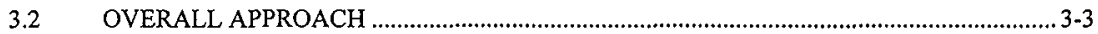

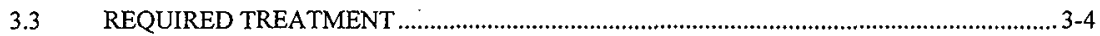

3.3.1 Remote-Handled Low-Level Mixed Waste.............................................................................3 3-5

3.3.2 Large Container Contact-Handled Low-Level Mixed Waste ................................................. 3-6

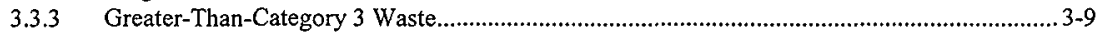

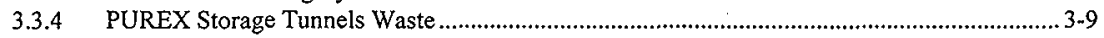

3.4 TREATMENT, STORAGE, AND/OR DISPOSAL PLANNED ACTIONS.......................... 3-9

3.4.1 Office of River Protection Tank Waste Remediation System Long-Length Equipment Macroencapsulation.......................................................................................................... 3-10

3.4.2 Failed Low-Activity Melters Macroencapsulation and Disposal ........................................... 3-10

3.4.3 PUREX Storage Tunnels Waste Disposition ............................................................... 3-12

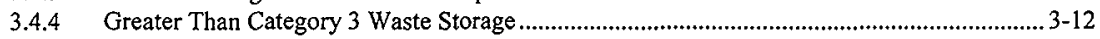

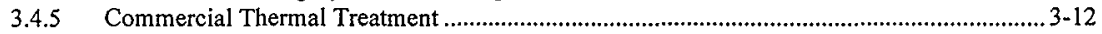

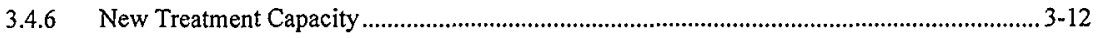

3.5 TREATMENT, STORAGE, AND/OR DISPOSAL CAPABILITY ................................... 3-15

3.5.1 Performance Requirements and Specifications ................................................................. 3-15

3.5.1.1 Waste Management Federal Services of Hanford, Inc. Planned Facilities ............................. 3-15

3.5.1.2 Office of River Protection Existing and Planned Facilities ................................................ 3-16 
3.5.2 Commercial Thermal Treatment 3-16

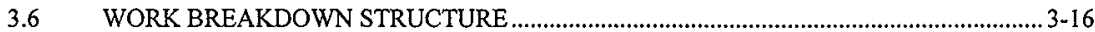

3.6.1 Office of River Protection Tank Waste Remediation System Facilities................................ 3-16

3.6.2 Tank Waste Remediation System-Privatization Facility ................................................... 3-17

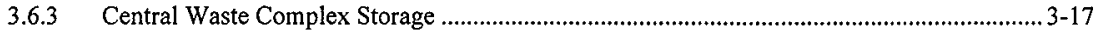

3.6.4 Waste Management Federal Services of Hanford, Inc. Planned Facilities .............................3-17

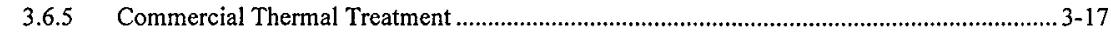

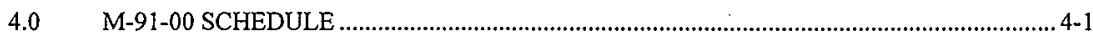

4.1 OFFICE OF RIVER PROTECTION TANK WASTE REMEDIATION SYSTEM

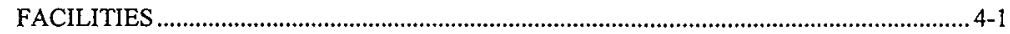

4.2 CENTRAL WASTE COMPLEX

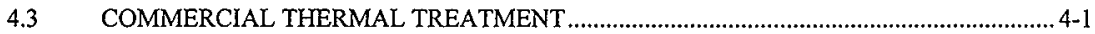

4.4 WASTE MANAGEMENT FEDERAL SERVICES OF HANFORD, NNC. PLANNED

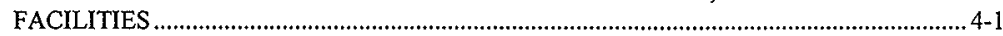

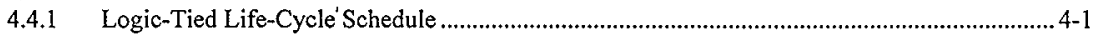

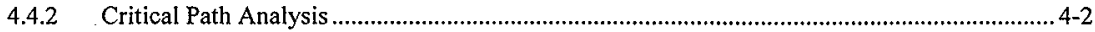

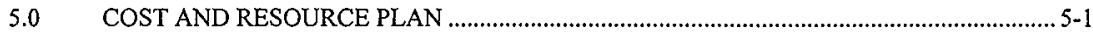

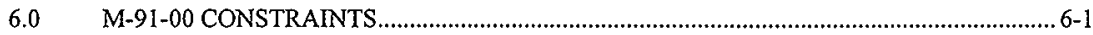

6.1 WASTE VOLUMES AND TREATMENT CAPACITIES ................................................6. $6-1$

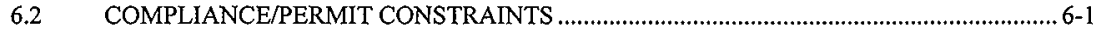

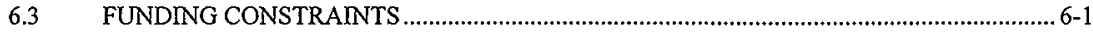

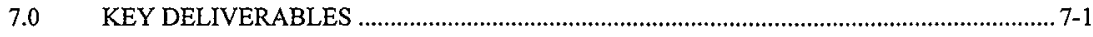

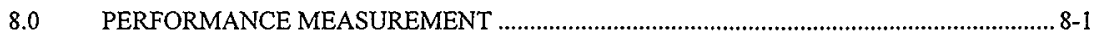

9.0 ORGANIZATION AND RESPONSIBILITIES ..........................................................

$10.0 \quad$ PROJECT INTERFACE CONTROL SYSTEM ............................................................10-1

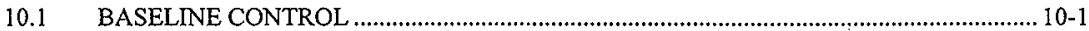

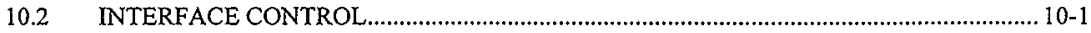

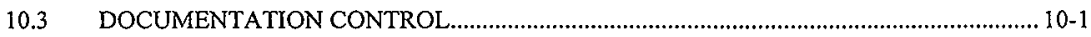

11.0 REPORTING AND NOTIFICATION REQUIREMENTS ........................................... 11-1

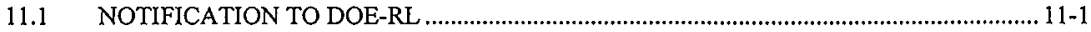

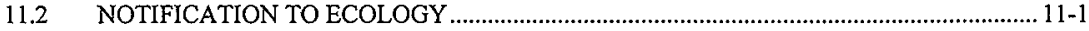

12.0 PROJECT CHANGE MANAGEMENT ........................................................................ 12-1

12.1 TECHNICAL BASELINE CHANGE CONTROL ….......................................................... 12-1

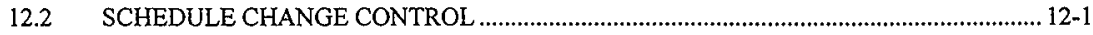

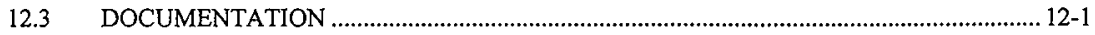


HNF-4293

\section{CONTENTS (cont)}

13.0 PROJECT QUALITY ASSURANCE ........................................................................... 13-1

13.1 QUALITY ASSURANCE POLICY....................................................................13-1

13.2 QUALITY ASSURANCE MANAGEMENT .................................................................. 13-1

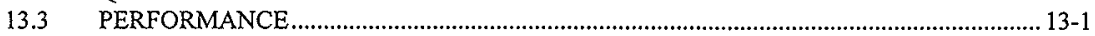

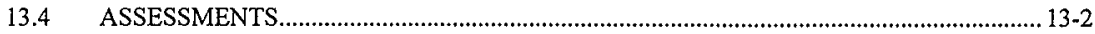

13.5 TRAINING AND QUALIFICATIONS ………......................................................... 13-2

13.6 AUTHORITY ...................................................................................................... 13-2

14.0 ENVIRONMENTAL MANAGEMENT ……………...................................................... 14-1

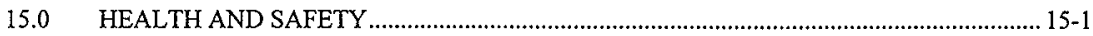

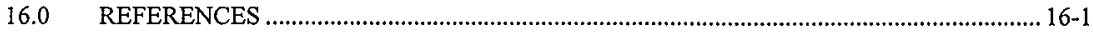

\section{APPENDICES}

A DRAFT TRI-PARTY AGREEMENT CHANGE CONTROL FORM................................APP A-i

B LOW-LEVEL MIXED WASTE DATA .................................................................. APP B-i

C WORK BREAKDOWN STRUCTURE (WBS) AND WBS DICTIONARY ……………... APP C-i

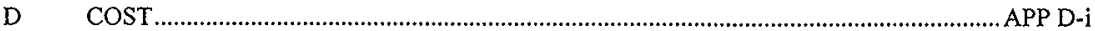

\section{FIGURES}

Figure 3-1. Required Land Disposal Restriction Treatment for the Projected Volumes of Remote-Handled Low-Level Mixed Waste.

Figure 3-2. Pretreatment and Required Land Disposal Restriction Treatment for the Projected Volumes of Large Container Contact-Handled Low-Level Mixed Waste............................ 3-8

Figure 3-3. Planned Treatment and Storage Facilities for Low-Level Mixed Waste. .......................... 3-13

Figure 3-4. Summary Work Breakdown Structure.......................................................................... 3-18

Figure 4-1. Project Summary Schedule........................................................................................ 4-3

Figure 9-1. Organizational Chart for M-91-10 Project Team. ……………………….......................... 9-1 
TABLES

2

3

4

5

6

7

8

9
Table 2-1. M-91-10 Waste Volume Comparison of 1996 Versus 1998 SWITS/SWIFT

Projections.

Table 2-2. M-91-10 Large Container Contact-Handled Low-Level Mixed Waste Volumes From 1996 Versus 1998 Volumes (SWITS/SWIFT) 2-4

Table 2-3. Remote-Handled Low-Level Mixed Waste From 1996 Versus 1998 Volumes (SWITS/SWIFT).................................................................................................... 2-5

Table 2.4. Greater-Than-Category 3 Waste Volumes in 1996 Versus 1998 Volumes. .......................2-6

Table 3-1. M-91-10 Required Land Disposal Restriction Treatment Categories.................................3-5

Table 3-2. Remote-Handled Low-Level Mixed Waste: Solid Waste Integrated Forecast Technical System Annual Forecast Volumes by Treatment Type (in cubic meters)........................... 3-11

Table 4-1. M-91-00 Summary Schedule..................................................................................... 4-2

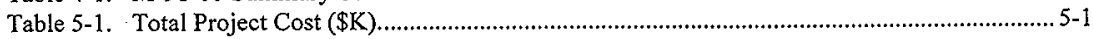


HNF-4293

ALARA

ATG

BHI

CERCLA

CDR

CFR

$\mathrm{CH}$

CTT

CWC

$D \& D$

DOE

DOE-RL

Ecology

EH\&S

EIS

EM-30

EM-40

EPA

ER

ERC

ERDF

FDC

FDH

FFCA

FY

GTC3

$\mathrm{Hg}$

$\mathrm{HNF}$

INEEL

ISB

ISMS

$\mathrm{Kg}$

\section{GLOSSARY}

as low as reasonably achievable

Allied Technology Group, Incorporated

Bechtel Hanford, Incorporated

Comprehensive Environmental Response Compensation and Liability Act of 1980

conceptual design report

Code of Federal Regulations

contact-handled

commercial thermal treatment

Central Waste Complex

decontamination and decommissioning

U.S. Department of Energy

U.S. Department of Energy, Richland Operations Office

Washington State Department of Ecology

Environmental Health \& Safety

environmental impact statement

DOE Office of Environmental Management

Environmental Restoration Program

United States Environmental Protection Agency

environmental restoration (also refers to the Environmental Restoration program)

environmental restoration contractor

Environmental Restoration Disposal Facility

functional design criteria

Fluor Daniel Hanford, Inc.

Federal Facilities Compliance Act of 1992

fiscal year

greater than Category 3

mercury

Hanford Nuclear Facility (document identifier)

Idaho National Engineering and Environmental Laboratory

integrated site baseline

Integrated Safety Management System

kilogram

land disposal restrictions

large equipment container

Low-Level Burial Ground 
HNF-4293

LLE

LLMW

LLW

mrem

MYWP

$\mathrm{nCi}$

N/A

NEPA

ORP

ORP TWRS

PCB

PHMC

PMP

PNNL

PPE

$\mathrm{Pu}$

PUREX

QA

QAPP

$R \& D$

REDOX

RCRA.

RH

ROD

SWB

SWIFT

SWITS

Tri-Party Agreement TRU

TSCA

TSD

TWRS-P

WAC

WBS

WIPP

WMH

w/o

\section{GLOSSARY (cont)}

long-length equipment

low-level mixed waste

low-level waste

millirem

multi-year work plan

nanocurie

not available or not applicable

National Environmental Policy Act of 1969

Office of River Protection (DOE)

Office of River Protection Tank Waste Remediation System

polychlorinated biphenyl

Project Hanford Management Contract

project management plan

Pacific Northwest National Laboratory

personal protective equipment

plutonium

plutonium-uranium extraction (Plant)

quality assurance

quality assurance program plan

research and development

reduction-oxidation (Plant)

Resource Conservation and Recovery Act of 1976

remote-handled

record of decision

standard waste box

Solid Waste Integrated Forecast Technical System

Solid Waste Inventory Tracking System

Hanford Federal Facility Agreement and Consent Order

transuranic

Toxic Substances Control Act of 1976

treatment, storage, and/or disposal

Tank Waste Remediation System-Privatization

Washington Administrative Code

work breakdown structure

Waste Isolation Pilot Plant

Waste Management Federal Services of Hanford, Inc. without (i.e., w/o Hg means without mercury) 


\section{EXECUTIVE SUMMARY}

The objective of this project management plan is to define the tasks and deliverables that will support the treatment, storage, and disposal of remote-handled and large container contact-handled low-level mixed waste, and the storage of Greater-than-Category 3 waste. The plan is submitted to fulfill the requirements of the Hanford Federal Facility Agreement and Consent Order Milestone M-91-10.

The plan was developed in four steps: (1) the volumes of the applicable waste streams and the physical, dangerous, and radioactive characteristics were established using existing databases and forecasts; (2) required treatment was identified for each waste stream based on land disposal restriction treatment standards and waste characterization data; (3) alternatives for providing the required treatment were evaluated and the preferred options were selected; (4) an acquisition plan was developed to establish the technical, schedule, and cost baselines for providing the required treatment capabilities. The major waste streams are tabulated below, along with the required treatment for disposal.

\begin{tabular}{|l|c|c|c|}
\hline \multirow{2}{*}{ Waste Form } & \multicolumn{2}{|c|}{ Waste Volumes (cubic meters) } & Treatment \\
\cline { 2 - 4 } & Stored & Forecast & Macroencapsulation \\
\hline $\begin{array}{l}\text { RH LLMW (all } \\
\text { containers) }\end{array}$ & 61 & 30,897 & $\begin{array}{c}\text { Sort/repack followed by } \\
\text { macroencapsulation or } \\
\text { thermal treatment }\end{array}$ \\
\hline $\begin{array}{l}\text { Large Container CH } \\
\text { LLMW }\end{array}$ & 196 & 0 & Storage only \\
\hline GTC3 & 1.3 & 0 & N/A \\
\hline Total Volume & $\mathbf{2 5 8}$ & $\mathbf{3 0 , 8 9 7}$ & \\
\hline
\end{tabular}

This plan calls for a sort/repack facility at the T Plant Complex for contact-handled waste in large boxes (up to 25 cubic meters). The waste would be reduced in size to fit into standard waste boxes. Organic debris and polychlorinated biphenyl waste would be sorted and repackaged for thermal treatment at a commercial facility, under an existing contract. A macroencapsulation facility would be set-up at the $\mathrm{T}$ Plant Complex to treat inorganic debris from the sorting operation and remote-handled waste packaged in shielded containers.

Long-length equipment retrieved from the Office of River Protection high-level waste tanks would be macroencapsulated and grouted at the tank farms, and delivered to Waste management Hanford for disposal. Equipment for this operation is located in the 200-East Area and is ready for use. The disposition plan for failed low-activity melters from Office of River Protection-Privatization operations is under negotiation. Also remaining for future resolution is a disposition plan for failed equipment in the PUREX Storage Tunnels. The existing 1.3 cubic meters Greater-than-Category 3 waste would be stored at the Central Waste Complex until a disposition path is determined.

The schedule for the needed modifications at $\mathrm{T}$ Plant Complex include completion of functional design criteria by September 1999; assessment of space, utilities, and permitting requirements beginning in October 2002; technology evaluation beginning in January 2003; equipment procurement and installation by March 2005; and startup by June 2005 .

Estimated project costs, incurred during fiscal years 2003 through 2005 , include $\$ 520 \mathrm{~K}$ of expense funding for project support and $\$ 580 \mathrm{~K}$ in capital funds. In addition, an estimated $\$ 2.8 \mathrm{M}$ would be required annually to restore full operational status of T Plant. 


\section{HNF-4293}

This page intentionally left blank. 


\subsection{INTRODUCTION}

Change Number M-91-96-01 of the Hanford Federal Facilities Agreement and Consent Order, known as the Tri-Party Agreement (Ecology et al. 1999), established a new major milestone, M-91-00, "to complete the acquisition of new facilities, modification of existing facilities necessary for storage, treatment/processing, and disposal of all Hanford Site transuranic, transuranic-mixed, low-level mixed (LLMW), and greater than Category 3 (GTC3) wastes." This Project Management Plan (PMP) fulfills the requirements of Tri-Party Agreement M-91-10 to submit a PMP that establishes all major tasks and deliverables related to the treatment, storage, and disposal (TSD) of Hanford Site remote-handled (RH) and large container contact-handled (CH) LLMW, and storage of GTC3 waste. A schedule with major milestones and decision points is included in this PMP. Draft Tri-Party Agreement Change Control Forms (change requests) are attached as Appendix A.

\subsection{PROJECT MANAGEMENT PLAN OBJECTIVES}

In accordance with the Tri-Party Agreement, the objectives are to establish treatment, storage, and disposal capacity for RH and Large Container CH LLMW, and storage of GTC3 waste through use of commercial treatment, construction of new facilities, or modification of existing facilities. Waste streams and volumes are defined and options are developed and analyzed using a systems engineering approach, as discussed in Section 3.2, to identify commercial treatment opportunities and the need for facility acquisition to meet Tri-Party Agreement objectives.

\subsubsection{TECHNICAL OBJECTIVES}

Specific technical objectives include identifying the treatment and pre-treatment process required for the given waste streams to meet land disposal restriction (LDR) standards per 40 Code of Federal Regulations (CFR) 268 and Washington Administrative Code (WAC) 173-303-140, acquiring treatment capacity by establishing links to the commercial sector, making optimal use of the existing commercial contracts and existing Hanford Site facilities, and the designing/building of new facilities or the retrofitting of existing facilities. In the absence of a conceptual design report (CDR) for new treatment capacity, the work breakdown structure (WBS) included in this PMP forms the technical baseline for future planning, design, and budgeting activities. Waste streams, projected volumes, and treatment processes necessary to dispose of waste to meet regulatory, environmental, safety, and health requirements, are defined in this PMP.

\subsubsection{SCHEDULE OBJECTIVES}

The schedule objectives are to define activities and timeframes to meet the M-91-00 subelement milestones, to identify the critical path for the startup of a treatment facility, to define dates for the deliverables, and to identify issues that may affect the schedule and require submission of Tri-Party Agreement Change Control Forms (change requests) for resolution. The project schedule presented in Section 4.0 will be used for performance measurement and will provide a means by which progress can be measured. 
HNF -4293

\section{$1 \quad$ 1.1.3 COST OBJECTIVES}

2 Costs developed are order-of-magnitude costs that will be used to establish budget-funding levels. The 3 costs are developed using the top-level WBS, project schedule, and a preliminary cost estimate of needed 4 onsite TSD units and offsite TSD Facility capacity. This estimate is within planning level degree of 5 accuracy, and cost numbers will be refined during the engineering phase. The degree of risk, or 6 contingency, was considered during the estimate development. 


\subsection{BACKGROUND}

WHC-SD-WM-ES-341, Rev. 0, Solid Waste and Materials System Alternatives Study presented alternatives to provide the necessary facilities to satisfy Tri-Party Agreement M-33-00. Alternatives were arrived at using a systems engineering approach. However, waste streams and materials that had significant uncertainties regarding disposition were not evaluated.

HNF-2063, Trade Study for the Processing, Treatment, and Storage of Hanford Site Solid Waste Streams That Have No Current Path Forward, evaluated the following alternative locations or facilities for the processing, treatment, and storage of the Hanford Site solid waste streams as identified by Tri-Party Agreement M-91-00:

- 2706-T Facility plus external modules

- T Plant Complex plus internal modules

- T Plant Complex conversion

- New modular facilities

- Washington Nuclear Power Plant 1

- Maintenance and Storage Facility conversion.

The trade study concluded that the use of the 2706-T/TA Facility plus newly constructed external processing modules, and the use of all newly constructed modular processing facilities, warranted further consideration. However, this study became irrelevant to the present situation because the study did not differentiate between transuranic (TRU) and LLMW facilities, waste streams volume forecast data were uncertain, and the required LLMW treatments were not defined.

The Canyon Disposal Initiative is an ongoing study under the purview of the Environmental Restoration Contractor (ERC), Bechtel Hanford, Inc. (BHI). The initiative is to evaluate the feasibility of using the canyons within the five chemical reprocessing facilities [U Plant, T Plant Complex, B Plant Complex, Reduction-Oxidation (REDOX) Plant, and Plutonium-Uranium Extraction (PUREX) Plant] for waste disposal. The conclusion and recommendations from this study are not anticipated until fiscal year 2001 . Canyon disposal is considered an unlikely disposition pathway for LLMW under the M-91-10 project scope as discussed under Assumption 6 in Section 3.1. In the event that the canyons become a viable disposition pathway, the canyons will only enhance the disposition options for LLMW.

\subsection{APPLICABLE WASTE STREAMS}

The LLMW stream, as defined in M-91-10, is obtained by completing data sorts on the waste storage and forecast databases. The LLMW waste streams in storage on the Hanford Site are identified as a subset of waste contained in the latest annual LDR Report prepared in accordance with TPA Milestone M-26 (DOE/RL-98-09). The solid waste inventory tracking system (SWITS) database contains reliable detailed data (e.g., volumes; container information; and radiological, physical, and dangerous waste characteristics) on each container of waste stored at the Central Waste Complex (CWC). Waste shipping records for the stored waste were used to extract detailed waste information as needed. Additional information can be found in the M-26 annual LDR Report (DOE-RL-98-09). TRU mixed waste is not addressed in this PMP as TRU mixed waste will be covered under the PMP for M-91-03.

The solid waste integrated forecast technical system (SWIFTS) database is used to forecast future waste stream volumes and characteristics using waste generator input. The waste generator enters basic 
information directly to the SWIFTS, such as the life cycle and the waste classes, and defines any nonstandard container or 'combined' dangerous waste characteristics. For each waste class, the waste generator specifies the containers in which the waste will be stored, the projected volume of waste, the physical form of the waste, the dangerous characteristics of the waste, and the radionuclides in the waste. The SWIFTS database is updated annually and the data published in the SWIFTS report (e.g., HNF-EP-0918, Rev. 4).

The SWIFTS data are validated through a stringent quality assurance (QA) process that includes sign off by appropriate authorities, checking for completeness of the computer generated form, and conducting intensive and extensive peer reviews. Significant changes in waste volume from previous years are identified and issues resolved before the report is published. Other waste streams that are not included in SWIFTS and that could be LLMW were identified by consulting the Office of River Protection (ORP) privatization program and reviewing the 1998 Report on Hanford Site Land Disposal Restrictions for Mixed Waste (DOE/RL-98-09).

\subsubsection{Overview}

Waste included in M-91-10 scope generally is created from facility stabilization/cleanup processes that include ORP Tank Waste Remediation System (ORP TWRS) cleanup operations, maintenance of process equipment, and laboratory operations.

The EM-40 waste generated by the Environmental Restoration (ER) Program on the Hanford Site is managed separately under the Comprehensive Environmental Response, Compensation, and Liability Act (CERCLA) of 1980 regulations and therefore is dispositioned under the ER Program milestones. The ER baseline currently identifies the Environmental Restoration Disposal Facility (ERDF) as the ultimate disposal site for all low-level waste (LLW) and LLMW removed during remedial actions/facility decommissioning and decontamination (D\&D). However, newly generated LLMW from ER operations is included in the M-91-10 scope if the waste is stored and required to be described in the annual LDR report.

Most of the M-91-10 waste consists of debris (refer to definition in Section 2.4) with minor amounts of granular waste and soil/gravel. Debris includes paper, plastic, protective clothing items, metals, lead shielding, and pieces of equipment. Soil/gravel and granular materials are generated by the ER Program and laboratory operations. M-91-10 debris varies in physical and chemical characteristics. Packages might contain inorganic debris (metal, concrete, etc.), organic debris (paper, plastic, wood) or a mixture of both organic and inorganic debris (heterogeneous).

All of the LLMW forecast volumes are expected to be generated between the current year and the year 2035 , after which no waste is expected to be generated. The stored inventory of LLMW is included in the M-91-10 scope as discussed in Section 2.2. Future waste generation is expected to be the same or similar to waste in the current inventory. Generating processes will not change significantly, as no further chemical or nuclear reprocessing operations other than cleanup activities are planned on the Hanford Site. Based on past and current activities, the forecast waste has been characterized by onsite generator personnel for matrix composition and dangerous and radioactive constituents.

The waste streams in storage on the Hanford Site are identified as a subset of waste contained in the latest annual LDR Report prepared in accordance with the TPA Milestone M-26. Forecasted mixed waste is identified through the SWIFT and other programmatic documents. 


\subsubsection{Applicable Waste Stream Volumes}

2 Life-cycle forecast and stored volumes, as well as other relevant information, for large-container $\mathrm{CH}$

3 LLMW, RH LLMW, and GTC3 waste obtained from the 1998 SWIFT forecast (HNF-EP-918) and a

4 SWITS search are presented in Appendix B. This section discusses the 1998 data in comparison with the

51996 projected data that were used as the basis for establishing the M-91-10 milestone.

6

The 1996 forecast volumes have changed from a total volume of 158,736 cubic meters to 29,405 cubic meters in 1998 as projected by SWITS/SWIFT and are summarized in Table 2-1. The primary reasons for the volume changes are attributed to the total elimination of GTC 3 waste $(89,189$ cubic meters) from the forecast, the redefinition of large and small containers (reducing the forecast from 29,583 cubic meters to 196 cubic meters), and the ORP TWRS revised forecast for large equipment containers (LEC) (from 32,983 cubic meters to 25,508 cubic meters). These three factors account for 126,050 cubic meters out of the total difference of 129,331 cubic meters between the original M-91 scope and the 1998 forecast. The RH LLMW other containers 3,281 cubic meters decrease is due to a revised forecast of volume.

At the time of the M-91 milestone negotiations, large containers were defined as boxes of any size, and small containers as drums. Large containers currently are defined as only boxes greater than 360 cubic feet or 10 cubic meters and small containers are defined as drums and boxes less than 10 cubic meters in volume. The total volume for $\mathrm{CH}, \mathrm{RH}$, and GTC3 waste shown in Table 2-1 is broken down by Program and discussed individually in the following sections.

Table 2-1. M-91-10 Waste Volume Comparison of 1996 Versus 1998 SWITS/SWIFT Projections.

\begin{tabular}{|c|c|c|c|}
\hline \multirow[t]{2}{*}{ Waste classification } & \multirow{2}{*}{$\begin{array}{l}1996 \text { projected } \\
\text { volumes } \\
\text { (cubic meters) }\end{array}$} & \multicolumn{2}{|c|}{$\begin{array}{l}1998 \text { volumes } \\
\text { (cubic meters) }\end{array}$} \\
\hline & & Stored & Forecast \\
\hline \multicolumn{4}{|l|}{ Large container CH LLMW } \\
\hline ORP TWRS LEC & 32,983 & 0 & 0 \\
\hline Large containers & $29,583^{*}$ & 196 & 0 \\
\hline Total CH LLMW & 62,566 & $\overline{196}$ & 0 \\
\hline \multicolumn{4}{|l|}{ RH LLMW } \\
\hline ORP TWRS LEC & 0 & 0 & 25,508 \\
\hline Other containers & 6,981 & 61 & 3,639 \\
\hline Total RH LLMW & 6,981 & 61 & 29,147 \\
\hline \multicolumn{4}{|l|}{ GTC3 waste } \\
\hline Total GTC3 waste & 89,189 & 1 & 0 \\
\hline Total waste volumes & 158,736 & 258 & 29,147 \\
\hline Total Projected Volume & 158,736 & \multicolumn{2}{|c|}{$29,405^{* *}$} \\
\hline
\end{tabular}




\subsubsection{Large Container Contact-Handled Low-Level Mixed Waste Volumes}

The large container CH LLMW volumes in the 1996 and 1998 SWITS/SWIFT projections are summarized by Program in Table 2 2 . There are 196 cubic meters of large container CH LLMW currently stored at CWC and there currently is no additional large container CH LLMW forecast. This represents a volume decrease of $99.7 \%$ from the projected waste volumes in 1996 .

Table 2-2. M-91-10 Large Container Contact-Handled Low-Level Mixed Waste Volumes From 1996 Versus 1998 Volumes (SWITS/SWIFT)

\begin{tabular}{|l|c|c|}
\hline \multicolumn{1}{|c|}{ Program } & $\begin{array}{c}\text { M-91-10 waste volumes } \\
\text { in 1996 (cubic meters) }\end{array}$ & $\begin{array}{c}\text { M-91-10 waste volumes } \\
\text { in 1998 (cubic meters) }\end{array}$ \\
\hline ORP TWRS (LEC) & 32,983 & 0 \\
\hline ORP TWRS & 6,064 & 0 \\
\hline Environmental Restoration & 7,590 & 0 \\
\hline Non-Programmatic & 7,167 & 0 \\
\hline Facility Transitions & 978 & 0 \\
\hline Solid Waste & 7,254 & 0 \\
\hline Pacific Northwest National Laboratory (PNNL) & 105 & 0 \\
\hline $\begin{array}{l}\text { Resource Conservation and Recovery Act } \\
\text { (RCRA) of 1976 }\end{array}$ & 425 & 196 \\
\hline Stored at CWC & NA & 196 \\
\hline CH LLMW Total & 62,566 & \\
\hline
\end{tabular}

A volume decrease of 32,983 cubic meters is a result of the reclassification of scrap long-length equipment (LLE) from CH LLMW to RH LLMW. At the time of the M-9I negotiations, the generator classified LLE as CH. As additional waste characterization information became available, this waste stream was reclassified as RH and the ORP TWRS revised forecast changed from 32,983 cubic meters to 25,508 cubic meters.

A volume decrease for large containers from 29,583 cubic meters in 1996 to 196 cubic meters in 1998 is attributed to a redefinition of large waste containers in 1998 to include only those boxes with a volume greater than 10 cubic meters as discussed earlier. $\mathrm{M}$-91-10 specifically states "large-container $\mathrm{CH}$ LLMW" only, thus small container CH LLMW is excluded from the M-91-10 scope. Small container CH LLMW treatment falls under the purview of Tri-Party Agreement M-19-00 (refer to Change Number M-19-95-01).

\subsubsection{Remote-Handled Low-Level Mixed Waste Volumes}

The RH LLMW waste volumes in 1996 are broken down by Program and compared to the current 1998 SWITS/SWIFT projected volumes in Table 2-3. The 1998 life-cycle volume projection for RH LLMW is 29,208 cubic meters, of which 61 cubic meters are stored at CWC. 
HNF-4293

Table 2-3. Remote-Handled Low-Level Mixed Waste From 1996 Versus 1998 Volumes (SWITS/SWIFT).

\begin{tabular}{|l|c|c|}
\hline \multicolumn{1}{|c|}{ Program } & $\begin{array}{c}\text { M-91-10 waste volumes projected in } \\
\text { 1996 (cubic meters) }\end{array}$ & $\begin{array}{c}\text { M-91-10 waste volumes in 1998 } \\
\text { (cubic meters) }\end{array}$ \\
\hline Environmental Restoration & 3,696 & 0 \\
\hline Non-Programmatic & 2 & 0 \\
\hline PNNL & 105 & 67 \\
\hline Solid Waste & 90 & 0 \\
\hline Facility Transitions & 4 & 25,508 \\
\hline ORP TWRS (LEC) & 0 & 3,492 \\
\hline ORP TWRS-other & 3,084 & 61 \\
\hline Stored at CWC & 19 & 29,208 \\
\hline RH LLMW Total & 6,981 & \\
\hline
\end{tabular}

Table 2-3 shows that the projected 22,227 cubic meters volume increase in RH LLMW results mainly from the reclassification of CH LEC to RH LEC and better forecast information (as discussed in the previous section). Specifically, RH LEC increased from 0 cubic meters to 25,508 cubic meters, not 32,983 cubic meters, because of better forecast information. The 3,696 cubic meters volume decrease from the ER Program is attributed to the RH LLMW generated from ER activities, falling under the direct purview of the ERC. The less significant volume decreases identified for other Programs also are attributed to adjustments in the current forecasts based on more accurate information.

\subsubsection{Greater Than Category 3 Waste Volumes.}

12 The projected GTC3 waste volumes in 1996 and 1998 are broken down by Program in Table 2-4 and shows that the 1998 life-cycle volume projection for GTC3 waste is 1 cubic meter, which is nearly a $100 \%$ reduction from the GTC3 volume projected in 1996. Current waste generator forecasts do not identify any GTC3 waste. Most of the GTC3 waste (88,024 cubic meters in Table 2-4) was forecast by ER/D\&D Programs in the form of $\mathrm{CH}$ and RH LLW/LLMW. According to assumptions that the ER Program used in the baseline to define waste that can be transferred from EM-40 to EM-30, all LLW and LLMW from remedial action and D\&D will go to ERDF. This implies that, even if GTC3 waste is 19 forecast by EM-40 (which does not appear likely), the GTC3 waste will go to ERDF as if the waste were 20 LLW/LLMW. 
Table 2-4. Greater-Than-Category 3 Waste Volumes in 1996 Versus 1998 Volumes.

\begin{tabular}{|l|c|c|}
\hline \multicolumn{1}{|c|}{ Program } & $\begin{array}{c}\text { Projected volumes in } \\
1996 \text { (cubic meters) }\end{array}$ & $\begin{array}{c}\text { Waste volumes } \\
\text { in 1998 (cubic meters) }\end{array}$ \\
\hline Environmental Restoration (CH LLW) & 39,942 & 0 \\
\hline Facility Transitions (CH LLW) & 2,384 & 0 \\
\hline Environmental Restoration (CH LLMW) & 4,259 & 0 \\
\hline PNNL (CH LLMW) & 14 & 0 \\
\hline Offsite (CH LLMW) & 34 & 0 \\
\hline Solid Waste & 69 & 0 \\
\hline Environmental Restoration (RH LLW) & 39,900 & 0 \\
\hline PNNL (RH LLW) & 33 & 0 \\
\hline Environmental Restoration (RH LLMW) & 1,539 & 0 \\
\hline PNNL & 14 & 1 \\
\hline Stored at CWC & $\mathrm{NA}$ & 1 \\
\hline GTC3 Total Waste Volume & $\mathbf{8 9 , 1 8 9}$ & 1 \\
\hline
\end{tabular}

\subsubsection{Failed Low-Activity Melters}

This waste stream, which is not included in the 1998 SWIFT forecast, could be LLMW and therefore needs to be addressed in this PMP. This waste stream has unique handling requirements because of size, shape, and radiological properties. Low-activity melters are glass melting equipment that will be used in the ORP TWRS Privatization (TWRS-P) Facility. Preliminary information indicates that the vitrification process will replace three melters every 3 -year cycle, producing on average, one failed melter per year. The failed melters will be characterized by the generator and dispositioned accordingly. Preliminary information indicates that each failed melter will likely be packaged in a 175-cubic meter container and will weigh about 300 metric tons. Ten failed melters (1,750 cubic meters) are projected over the life cycle of the TWRS-P Facility once operations have commenced.

\subsubsection{PUREX Storage Tunnels}

Some of the waste stored in the tunnels, which is not included in the 1998 SWIFT forecast, potentially could be LLMW and therefore needs to be addressed in this PMP. A review of records indicated approximately 242 cubic meters of RH LLMW in the PUREX Storage Tunnels (Appendix B). This volume represents only a small fraction of the waste stored in the tunnels. The PUREX Storage Tunnels waste consists primarily of failed or obsolete equipment, and therefore is considered debris. The issues surrounding the PUREX Storage Tunnels and waste disposition are discussed in Section 3.1. Information concerning the PUREX Storage Tunnels waste inventory is contained in the Hanford Facility RCRA Permit, Part III, Chapter 3.

\subsubsection{Waste Characterization}

Detailed waste information including the physical forms, characteristics, numbers, types, container information, and the dangerous properties for each stored/forecast waste stream is provided in Appendix B. The classification of the waste was based on the categories in the DOE Waste Treatability Group Guidance Document (DOE/LLW-217, Rev. 0). The dangerous properties assigned to the waste were based on the Washington State Department of Ecology (Ecology) Dangerous Waste Regulations, 
Washington Administrative Code (WAC) Chapter 173-303. Several dangerous properties might be present in a particular waste (e.g., a 208-liter drum might contain both ignitable and corrosive waste).

\subsection{WASTE STREAM STABILITY AND CONTAMINANT MIGRATION}

The applicable LLMW waste is either currently stored in CWC or will be newly generated. The stored waste is containerized and maintained within compliant conditions for dangerous and/or mixed waste governed by WAC 173-303 regulations and radioactive waste governed by DOE Orders. The integrity of the containment is monitored and inspected to ensure that release to the environment does not occur. Forecast waste will be received in containers and will be subject to all waste acceptance criteria and applicable inspection procedures. Any waste treated by the generator is assumed to be radiologically, chemically, and physically stable.

\subsubsection{Radiological Stability of Waste Forms}

The waste forms are solid and dry debris and this physical form does not readily allow migration or spread of radioactive contamination. Accidental release of radionuclides is prevented by the use of approved packaging methods and containers, the integrity of which is monitored closely. Criticality occurrence is not a credible scenario for LLW, which, by definition, contain less than 100 nanocuries per gram concentrations of TRU radionuclides.

Other areas of possible concerns when treating and storing mixed waste, include gas and heat generation. Under special conditions, gas generation may occur when radiolytic decay is strong enough to cause release of hydrogen from organic material such as plastics. Gas generation is a concern more relevant to waste containing greater quantities of TRU radionuclides than does LLW; hence, gas generation is not a credible concern for LLMW. Similarly, heat generation is a concern for certain isotopes, including plutonium-238; however, little or no inventory of plutonium-238 is expected in the LLMW. SWITS database contains the provisions to automatically perform calculations of suspect waste to identify those with heat or gas generation potential.

\subsubsection{Chemical Stability of Waste Forms}

Waste is segregated by waste type and chemical characteristics into containers at the point of generation in adherence with procedures and permit requirements. Waste Management Federal Services of Hanford, Inc. (WMH) further segregates the waste containers received into different areas at the CWC based on chemical hazards. Incompatible waste or waste with special storage requirements is segregated to reduce the risk of accidental events such as chemical reactions, explosion, and/or fire. Therefore, acidic waste is stored in separate areas from caustics, and flammable materials are stored in accordance with safety requirements.

\subsubsection{Areas of Contamination}

No known releases have occurred from the storage of waste types discussed in this PMP. 


\subsection{EXISTING TREATMENT CAPACITY AND OPTIONS CONSIDERED}

There is no existing commercial or DOE treatment capacity for RH LLMW.

There are two existing commercial contracts for the treatment of small container CH LLMW between WMH and Allied Technology Group, Inc. (ATG) that involve thermal destructive treatment and nonthermal treatment of debris and non-debris. The CH LLMW thermal treatment contract requires that ATG begin treating waste by November 2000,5 years from contract award. The 5 -year startup period is to be used by ATG to complete a National Environmental Policy Act (NEPA) of 1969 environmental assessment, obtain required licenses and permits, and design and construct treatment facilities. WMH is committed to have 120 cubic meters of CH LLMW treated per year for 5 consecutive years starting in fiscal year (FY) 2001. WMH has the option of having up to 597 cubic meters of additional waste treated during each of the 5 years. After the 5 years, WMH has the option of having up to 310 cubic meters per year treated for 5 additional years.

The non-thermal treatment contract with ATG was amended in July 1998 to accommodate a delay in the ATG RCRA permit application. The contract currently calls for treatment to start in June 1999 and specifies that 560 cubic meters of debris and/or non-debris waste be treated to meet LDR in FY 1999. WMH has the option to treat up to an additional 700 cubic meters of debris and 100 cubic meters of nondebris in FY 2000, and an additional 500 cubic meters of debris in FY 2001.

The Waste Experimental Reduction Facility (WERF) incinerator at the Idaho National Engineering and Environmental Laboratory (INEEL), Idaho Falls, Idaho, is not a viable option for Hanford Site waste because of low plutonium acceptance limits, and the inability of WERF to accept/manage RH waste. Similarly, the Oak Ridge National Laboratory, Oak Ridge, Tennessee, incinerator accepts only liquids. The waste acceptance criteria for the Consolidated Incinerator Facility at the Savannah River Site does not allow for the acceptance of non-Savannah River waste.

Four LLMW processing alternatives were evaluated in DOE/EA-1135, Environmental Assessment for Offsite Thermal Treatment of Low-Level Mixed Waste. All four alternatives were considered infeasible. Alternatives included: (1) no treatment, (2) construction of a treatment facility in the 200 West Area of the Hanford Site, (3) treatment of the waste at either an existing facility or a proposed facility at INEEL, and (4) treatment at a proposed facility at Oak Ridge, Tennessee.

The T Plant Complex, currently permitted for RCRA treatment (including sorting and repackaging), will be an option considered during evaluation for processing discussed in this PMP. Non-thermal treatment processes have been performed at $T$ Plant Complex in the past, including stabilization, decontamination and macroencapsulation.

\subsection{REGULATORY REQUIREMENTS}

Facilities for LLMW must meet the requirement for TSD units under the following applicable regulations.

WAC 173-303 is the primary regulation controlling dangerous waste management of the waste discussed in this PMP. WAC 173-303 regulations encompass cradle to grave management of mixed waste.

Compliant storage area and transportation systems are in place on the Hanford Site. This PMP discusses a means of treating the waste to meet applicable treatment standards set forth in the WAC-173-303-140. 
1 The LDR regulations (40 CFR 268) establish treatment standards by constituent concentration levels or 2 by designated treatment for waste and debris. 40 CFR 268 also provides for treatability variances or the 3 ability to prepare an application demonstrating an alternate treatment method is achievable for certain wastes. Petition provisions are also contained in the WAC-173-303 similar to the 40 CFR 268 provisions.

Debris is defined [40 CFR 268.2(g)] as solid material exceeding a 60 millimeter particle size that is intended for disposal and that is a manufactured object, or plant or animal matter, or natural geologic material. Debris is also defined in WAC 173-303-040. When a waste meets the definition of debris and is a hazardous debris, the treatment standards in 40 CFR 268.45 must be used. A mixture of debris and waste are subject to regulation as debris if the mixture consists primarily of debris, by volume, based on visual inspection.

WAC 173-303-140 (4)(d) prohibits the land disposal of organic/carbonaceous waste as defined in WAC 173-303-140 (3)(c). Organic/carbonaceous waste must be incinerated as a minimum management method according to the dangerous waste priorities in WAC 173-303-140(1)(d). Currently in effect as of December 1998, the state-only LDR does not apply to Hanford Site mixed waste based on proper execution of the 1,609 kilometers certification described in WAC 173-303-140(4)(d)(iii). When ATG begins operations, it is expected that Ecology will determine that treatment capacity is available for $\mathrm{CH}$ LLMW. The state-only LDR will not apply to RH LLMW because ATG does not have RH treatment capacity.

All applicable DOE requirements for nuclear controls and safety will be implemented and are expected to have minimal impact on LLMW. 
INNF-4293

1

2

3

4

5

This page intentionally left blank. 
HNF-4293

\subsection{PROJECT SCOPE}

This M-91-10 PMP has been developed using the following approach.

\subsection{ASSUMPTIONS AND BASES}

The following key assumptions and bases were developed for the PMP using the best available engineering, operations, waste treatment, and regulatory experience.

1. The FY 1998 forecast waste volumes in the SWIFT report (HNF-EP-0918) are an accurate baseline for M-91-10 PMP.

Rationale: The supplied data have undergone adequate levels of review (refer to Section 2.1). Current efforts integrate supplied data with the onsite disposition waste mapping effort. The SWIFT report is used by waste management contractors and by WMH for planning and business decisions.

2. DOE Complex EM Integration waste streams are not included in this project.

Rationale: EM Integration is not established as a baseline. Equity issues among States remain to be resolved. The impact for this $\mathrm{PMP}$ is minimal, because no offsite waste stream is scheduled to be shipped to a M-91-10 RH treatment facility. Federal Facility Compliance Act (FFCA) of 1992 waste has been considered, but these waste streams do not fit within the M-91-10 category. Forecasts to be used are the 1998 SWIFT report baseline volumes.

3. ORP TWRS LLE will be treated by macroencapsulation by ORP TWRS and will be disposed directly onsite in a Subtitle C Landfill, or additional Subtitle $\mathrm{C}$ units that might need to be constructed.

Rationale: This assumption is based on the current ORP TWRS retrieval project baseline as described in Long-Length Contaminated Equipment Disposal Process Path Document, HNF-SD-WM-ER-730.

ORP TWRS will use treatment-by-generator provisions to perform debris rule macroencapsulation of the LLE upon generation. As a backup position, existing T Plant Complex concrete pad areas, which have been used to macroencapsulate LLE, also could be used in the future. The T Plant Complex Part A, Form 3, Permit Application allows treatment activity within the area boundary ('fence line') (DOE/RL-88-21). Landfill disposal space requirements will be determined for the overall solid waste operation, taking into account all programmatic needs and annual rate of waste disposal.

4. The failed low-activity melters, if characterized as LLMW, will be treated by TWRS-P and will be disposed directly onsite in an existing Subtitle $\mathrm{C}$ landfill, or additional Subtitle $\mathrm{C}$ units that might need to be constructed.

Rationale: Maintenance, removal, and treatment of the low-activity melters are within the purview of TWRS-P once operations have commenced and are pending overall privatization negotiations. If classified as LLMW, treatment will meet LDR requirements and disposal will occur in a Subtitle C landfill. Therefore, this PMP does not address the treatment of this waste stream. The waste stream is discussed in Section 2.0. Landfill disposal space requirements will be determined for the overall solid waste operation, taking into account all programmatic needs and annual rate of waste disposal. 
5. Contaminated soil and gravel from cleanup of ORP TWRS tank farms will meet LDR (or contained-in) concentration limits for the listed constituents as-is, and treatment will not be required.

Rationale: Historical data from tank waste analysis indicated that the dangerous waste constituents in the tank waste are at concentrations below the LDR treatment standards. Analytical data on existing soil waste also indicated that the radioactive components are at concentration limits below treatment standards. It follows, therefore, that soil contaminated from occasional spills from tank farm cleanup activities will meet LDR standards. The soil and gravel will be sampled and analyzed before disposal in a Subtitle C Landfill. The waste stream will be managed as a mixed waste and might undergo a 'contained-in' determination process, if required.

6. The Canyon Disposal Initiative will not be used as a disposition pathway for waste identified in this PMP.

Rationale: The Canyon Disposal Initiative is speculative at this time but, if implemented, will increase disposal capacity and could mitigate disposal space constraints.

7. This PMP does not provide plans for acquiring a facility that will accommodate treatment of the PUREX Storage Tunnels waste.

Rationale: Any retrieval and treatment options for the PUREX Storage Tunnels waste will require major decisions from DOE, Project Hanford Management Contract (PHMC) management, regulators, and stakeholders. Planning a treatment facility for this waste before policy decisions are made is highly speculative and would incur high risk. Major technical issues need to be resolved, and if retrieval of waste from the tunnels were conducted, a large facility with specific capabilities for the retrieval project would be required.

The PUREX Storage Tunnels Closure Plan (Hanford Facility RCRA Permit, Part III, Chapter 3) states that closure of the PUREX Storage Tunnels requires coordination with closure of the PUREX Plant to ensure a cost effective closure for both units. The PUREX Storage Tunnels will be managed as a RCRA storage unit until closure can be coordinated with the final closure plan for the PUREX Plant.

\section{Solid Waste Environmental Impact Statement (EIS) Record of Decision (ROD) will cover the} implementation of the PMP objectives.

Rationale: The options in the EIS are general, allowing for practical means of implementing dispositions. A draft project work plan will be available before the EIS is finalized and before the draft ROD is initiated in December 1999, as currently scheduled. Furthermore, this PMP will be submitted before the final ROD is issued, thus providing a window of opportunity for alignment.

9. B Plant Containment Building Storage waste will be addressed in M-20-21A.

Rationale: The B Plant Containment Building Storage waste (as described in DOE/RL-98-09) is estimated at 97,000 kilograms of failed equipment (e.g., process jumpers, pumps, etc.). This waste must be properly characterized and packaged before treatment can be performed and is presently covered under M-20-21A, "Submit B Plant Pre-Closure Plan". A portion of this waste will be RH LLMW and will be fully characterized and packaged to meet onsite waste acceptance criteria (HNF-EP-0063) and will be macroencapsulated under M-91-00. 
10. Disposition of waste stored at the T Plant Complex will occur on a similar path as the PUREX Facility and the B Plant Complex.

Rationale: The T Plant Complex is a canyon facility on the Hanford Site. Canyon facilities have been managed pursuant to Key Facility provisions of the Tri-Party Agreement.

\subsection{OVERALL APPROACH}

A systems engineering graded approach was applied to derive the desired outcome of a disposition plan for each applicable LLMW stream as required by the Tri-Party Agreement. Systems engineering is 'a generalized, systematic methodology for defining large, complex, and/or first of a kind problems, and evaluating and implementing solutions'. The M-91-10 project has a relatively small scope, but the regulatory, technical, and technological issues involved are of moderate to high complexity. Project planning, outlined as follows, was structured to include all the elements of the systems engineering methodology. These include mission analysis, functional analysis, requirements analysis, system synthesis and integration, and alternative evaluation. The project mission was established by the Tri-Party Agreement major milestone M-91-10 and consists of developing TSD for applicable LLMW and GTC3 waste. The project was developed using the following steps.

1. Define the waste streams. The physical, dangerous, and radiological characteristics of the applicable LLMW and GTC3 waste streams were defined and bounded based on the Tri-Party Agreement terms and requirements, and the assumptions described in Section 3.1. Using the established waste characteristics as search parameters, the SWITS/SWIFT databases were searched to obtain a sitewide listing of waste streams and associated attributes including volumes, dangerous and radiological characteristics, type of packaging, shielding, and container size. In the case of stored waste, packaging records were accessed to obtain detailed information on container contents and characteristics. Waste streams that are not included in SWITS or SWIFT (e.g. low-activity melters, PUREX Storage Tunnels waste, and waste stored in other facilities) were identified by consultation with the programs responsible for the waste, the annual LDR Report, and the regulators. The applicable waste streams are presented in Section 2.1.

2. Define required treatment to meet applicable $L D R$ standards. Required treatment was identified for each waste stream, regardless of size, based on LDR treatment standards and waste characterization data (available or forecast). The waste streams were divided into treatability groups, i.e., waste streams with similar physical, chemical, and radiological characteristics that can be treated to LDR standards with the same process. The number of treatability groups defines the number of treatment processes required.

3. Define and evaluate options for providing the required treatment. The development of treatability groups, the aggregate waste volumes, and the corresponding number of treatment processes made it possible to determine the type and size of the required treatment facilities. A regulatory exemption or exclusion will be proposed if the treatment is not appropriate for a given waste stream. Treatment options were evaluated and selected based on waste volume to be treated, availability of planned commercial/site treatment facilities, and potential impact on public and labor relations.

4. Plan acquisition. An acquisition plan was developed for the selected options that include creation of new treatment capacity, as well as the use of existing Hanford Site facilities or planned commercial treatment opportunities. The acquisition plan includes a schedule with major decision points and milestones, and a preliminary cost estimate that could be used to develop the project funding profile. 
The acquisition plan also serves to establish the technical, schedule, and cost baselines for the project.

\subsection{REQUIRED TREATMENT}

Using the approach described in Section 3.2, the required LDR treatment was assigned to each waste based on available or forecasted physical, chemical, and radiological characteristics. Waste types with similar characteristics and treatment requirements were grouped and assigned the same treatment process. The required treatment processes were identified for all M-91-00 waste, regardless of volume. A brief and generic description of the selected treatment processes are provided for information.

Macroencapsulation. This is an LDR treatment standard for hazardous debris and has no contaminant restrictions. This is an immobilization technology consisting of an application of surface coating materials such as polymeric organics (e.g., resins and plastics) or use of a jacket of inert inorganic materials to substantially reduce surface exposure to potential leaching media. A process must be selected among the various existing technologies and must be compatible with the physical, chemical, and radiological properties of the waste. The encapsulating material must completely encapsulate debris and be resistant to degradation by the debris and the contaminants and materials into which the debris might come into contact after placement (leachate, other waste, microbes). Polyethylenes and commercially developed resins are examples of suitable encapsulating materials.

Stabilization. Chemical stabilization is a treatment technology for (non-debris) waste that contains heavy metals or other specific dangerous components. A stabilization process could be used for neutralization and solidification of liquid waste. The objective of stabilization is immobilizing the dangerous constituents through fixation, low solubility, and encapsulation. Stabilization is accomplished by mixing the waste with Portland cement or pozzolanic materials at a pre-selected ratio. The stabilized waste must meet the standards in the toxic characteristics leaching procedure (WAC 173-303-090) before land disposal.

Thermal treatment. Thermal treatment is a process where organic matter is destroyed in high temperature processes including combustion, such as incineration, boilers, industrial furnaces, and gasification processes that perform under reducing atmospheres. The energy requirement for the systems could be derived from combustion, electrical power, high temperature plasma, or a combination of energy sources. The energy source might act on the waste directly or the waste could be added to a heated medium such as molten glass. Thermal treatments must comply with stringent requirements of 40 CFR 268.42 and Subpart $O$.

Thermal treatment is a technology-based treatment standard for organic/carbonaceous waste containing dangerous components. Sampling and system monitoring must prove that mandatory destruction efficiency levels are met. Residues from thermal processes (bottom ash, slag, glass, and air pollution control residues) might require stabilization to meet LDR requirements before disposal.

Organic destruction. Organic destruction is a generic process that could be used to destroy organic dangerous constituents that have a concentration-based treatment standard. Such a process could be selected from available technologies including chemical oxidation, chemical reduction, or thermal treatment depending on the volume and characteristics of the waste. The residues from this process might require further treatment that could include stabilization, solidification, or reactant recovery. 
1 Drain and rinse. This is a Toxic Substance Control Act (TSCA) of 1976 treatment standard for 2 polychlorinated biphenyls (PCB) contaminated (greater than 500 parts/million) transformers. The 3 treatment consists of draining the transformers and conducting an 18 hour rinse with an organic solvent 4 that is at least $5 \%$ soluble with PCB oil according to prescribed methodology. The rinsate can be treated 5 thermally.

\subsubsection{Remote-Handled Low-Level Mixed Waste}

9 The required treatments for RH LLMW are shown in Table 3-1 for each waste stream.

10

11

12

Table 3-1. M-91-10 Required Land Disposal Restriction Treatment Categories.

\begin{tabular}{|c|c|c|c|}
\hline \multirow[t]{2}{*}{ Waste form } & \multicolumn{2}{|c|}{ Waste volumes (cubic meters) } & \multirow[t]{2}{*}{ Treatment } \\
\hline & Stored & Forecast & \\
\hline \multicolumn{4}{|l|}{ RH LLMW } \\
\hline Debris - inorganic & 61 & $2,904.5$ & Macroencapsulation \\
\hline Debris - organic & 0 & 576.4 & Macroencapsulation \\
\hline Inorganic homogeneous solids & 0 & 20.0 & Stabilization \\
\hline Inorganic homogeneous solids & 0 & 11.2 & Organic destruction \\
\hline Lab packs & 0 & 0.1 & Stabilization/neutralization \\
\hline Lab packs & 0 & 0.1 & Organic destruction \\
\hline Organic homogeneous solids & 0 & 11.2 & Organic destruction \\
\hline Organic homogeneous solids & 0 & 36.1 & Stabilization/neutralization \\
\hline Soil/gravel & 0 & 78.6 & Disposal \\
\hline Soil/gravel & 0 & 0.9 & Stabilization \\
\hline Special waste & 0 & 0.1 & Stabilization/neutralization \\
\hline LLE & 0 & 25,508 & Macroencapsulation \\
\hline Low-activity melters & 0 & 1,750 & Macroencapsulation \\
\hline RH LLMW Total & 61 & 30,897 & \\
\hline \multicolumn{4}{|l|}{ Large Container CH LLMW } \\
\hline Debris-heterogeneous & 64 & 0 & $\begin{array}{l}\text { Sort/macroencapsulation/ } \\
\text { Thermal treatment }\end{array}$ \\
\hline Debris-organic w/PCB & 11 & 0 & Thermal treatment \\
\hline Debris-heterogeneous w/PCB & 12 & 0 & $\begin{array}{l}\text { Sort/macroencapsulation/ } \\
\text { Thermal treatment }\end{array}$ \\
\hline Debris-inorganic & 91 & 0 & Macroencapsulation \\
\hline PCB transformer & 18 & 0 & Drain and rinse \\
\hline CH Total & 196 & 0 & \\
\hline \multicolumn{4}{|l|}{ GTC3 Waste } \\
\hline GTC3 waste & 1.3 & 0 & n/a (storage only) \\
\hline GTC3 Waste Total & 1.3 & 0 & \\
\hline Total Volume & 258 & 30,897 & \\
\hline
\end{tabular}


Figure 3-1 shows a block diagram identifying the waste feed streams, the stored and forecast total volumes for each waste stream, the required LDR treatment, and the annual volume rates for each treatment process.

Macroencapsulation. Macroencapsulation is selected as a LDR treatment for both inorganic and organic/carbonaceous RH debris. This is based on the assumption that the WAC 173-303 LDR on organic/carbonaceous waste (refer to Section 2.4) will not apply because no $\mathrm{RH}$ thermal treatment process is known to be available within a 1,609 kilometer radius from the borders of Washington State. Heat and hydrogen gas generation is not a concern for macroencapsulation of these wastes (refer to discussion in Section 2.2.1).

The LLE also will require treatment by macroencapsulation in LEC. However, because of the size, configuration, and specific handling requirements, the ORP TWRS will use a specially designed macroencapsulation system to treat LLE debris. Therefore, it is apparent that this LLE treatment system is not suitable to treat other M-91-10 debris.

The low-activity melters are considered for $\mathrm{RH}$ macroencapsulation because this debris is listed (derived from) and could be contaminated with heavy metals.

Stabilization. As shown in Figure 3-1, stabilization is the selected technology for all of the RH organic and inorganic homogeneous solids, and other non-debris waste that contains heavy metals. Included in this category are special wastes, soil/gravel, and lab packs as listed in Table 3-1. The residue from the organic destruction process also is identified for stabilization and/or solidification if heavy metals are present or the residual stream is liquid.

Organic Destruction. Organic destruction is the selected technology for all of the RH organic and inorganic homogeneous solids and tab packs that contain organic dangerous constituents. This selection is presented as alternate treatment to thermal treatment because the volumes are small and a chemical destruction process will be more amenable to $\mathrm{RH}$ operation. Residues from organic destruction will be evaluated to determine if stabilization/neutralization is required prior to land disposal.

Direct Disposal. Because it is expected that some soil and gravel meet LDR (or contained-in) concentration limits (Assumption 5, Section 3.1) for the listed constituents as received, direct disposal of such waste to a Hanford Site Subtitle C Landfill could be made without having to perform treatment.

\subsubsection{Large Container Contact-Handled Low-Level Mixed Waste}

38 The required treatment categories for the various large container CH LLMW forms identified in 39 Table 3-1 are drain and rinse, thermal treatment, and macroencapsulation. Figure 3-2 is a block diagram 40 identifying the required treatment, the feed waste streams, the stored and forecast total volumes for each 41 waste stream, and the annual volume rates for each treatment process. 


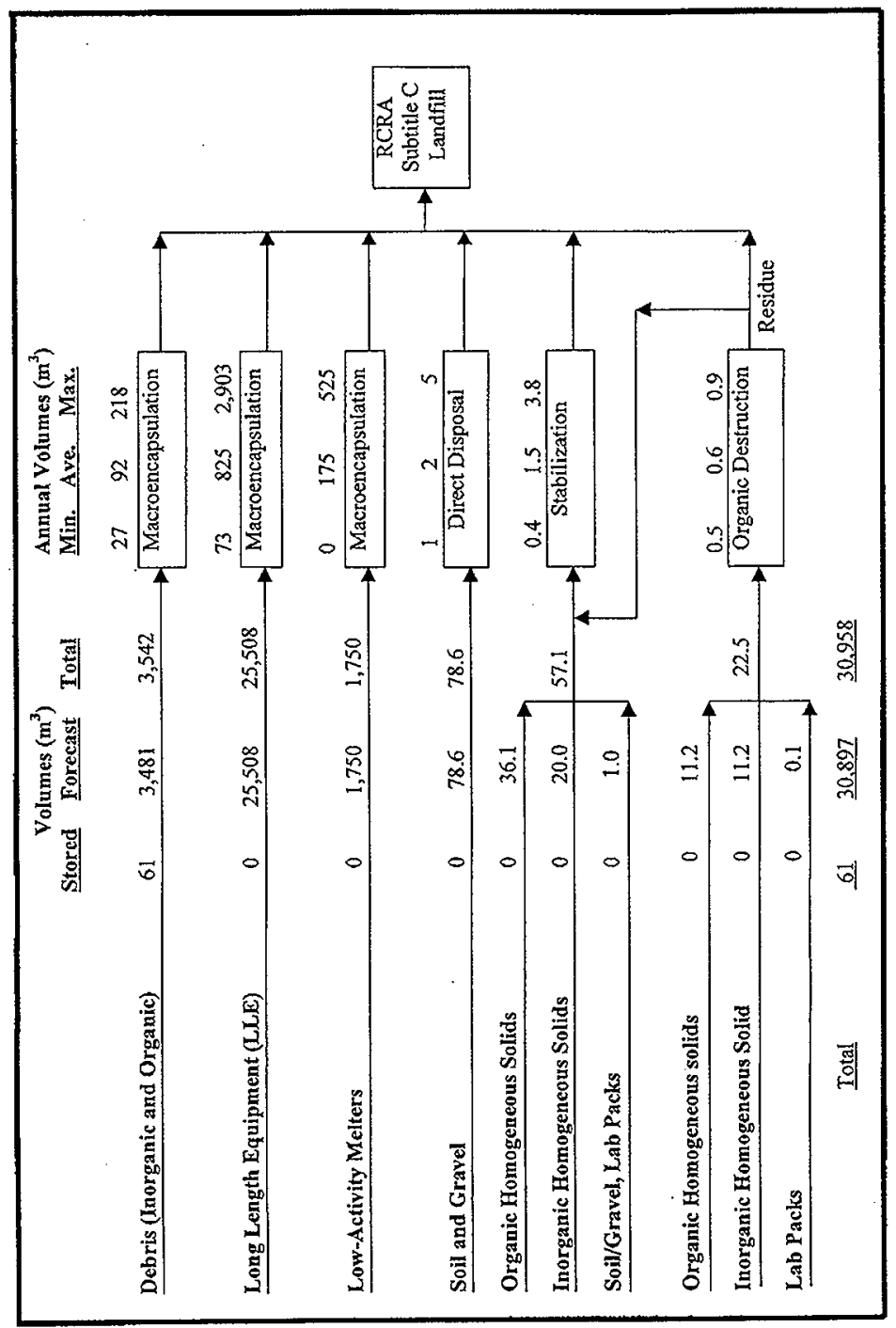

Figure 3-1. Required Land Disposal Restriction Treatment for the Projected Volumes of Remote-Handled Low-Level Mixed Waste. 


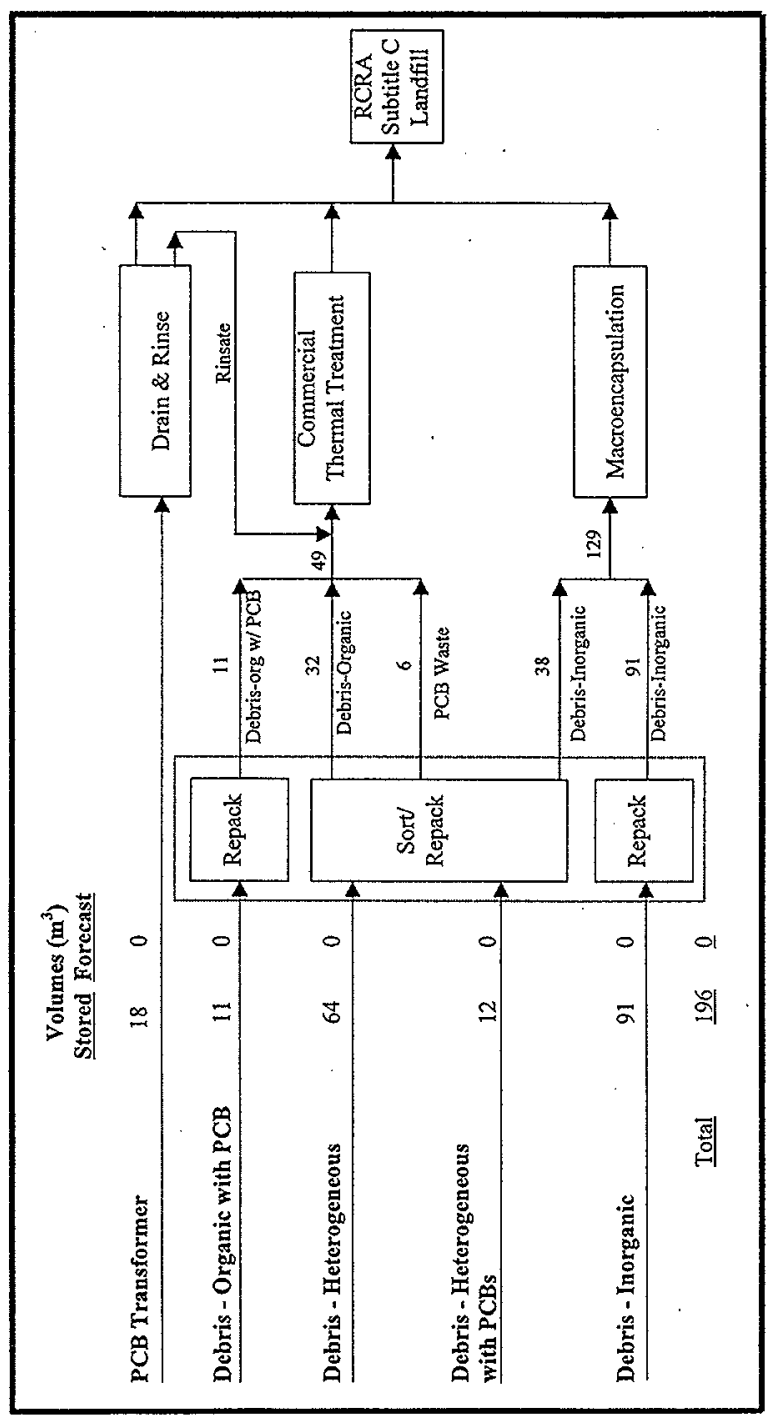

Figure 3-2. Pretreatment and Required Land Disposal Restriction Treatment for the Projected Volumes of Large Container Contact-Handled Low-Level Mixed Waste. 
Sort/Repackage. Sorting is selected for heterogeneous debris streams to separate organic/carbonaceous debris (organic) from non-organic/carbonaceous (inorganic) debris. According to records, one heterogeneous debris container includes PCB sludge that requires separation as an additional PCB waste stream. The heterogeneous debris will be sorted and repackaged into inorganic and organic debris streams. The heterogeneous debris with PCB will be sorted into inorganic debris, organic debris, and PCB waste.

Because all the CH LLMW is packaged in large containers, repackaging the waste in small containers is performed to accommodate subsequent treatment processing.

Drain and Rinse. There is one PCB transformer stored at CWC that may require drain and rinse treatment per TSCA regulations. The rinsed transformer will be disposed in a Subtitle C Landfill in compliance with TSCA checklist requirements and the rinsate sent for thermal treatment. Records indicate that this transformer has been drained and rinsed, but it is not clear whether the method used satisfies TSCA regulations. The issue will be investigated before deciding on the final disposition path.

Commercial Thermal Treatment (CTT). CTT is selected for organic/carbonaceous and PCB waste resulting from the sort/repack operation to satisfy the state-only LDR on organic/carbonaceous waste and TSCA regulations.

Macroencapsulation. Macroencapsulation is the selected LDR treatment for the inorganic debris streams obtained from the sort/repack operation.

\subsubsection{Greater-Than-Category 3 Waste}

All GTC3 waste will be stored per the Tri-Party Agreement until national guidelines for disposal are issued by DOE-Headquarters, or appropriate reviews are performed in accordance with DOE Orders. An implementation plan will be prepared that addresses GTC3 disposition.

\subsubsection{PUREX Storage Tunnels Waste}

As discussed in Section 3.1, this PMP does not provide plans for the option of removal and treatment of the PUREX Storage Tunnels failed equipment. The final disposition plan will be developed as described in Section 3.1.

\subsection{TREATMENT, STORAGE, AND/OR DISPOSAL PLANNED ACTIONS}

This section defines and describes the programs, planned actions, and existing or new facilities required for the TSD of large container CH LLMW, RH LLMW, and GTC3 waste described in Section 2.0 and treated according to Section 3.3. The planned actions/facilities were defined by evaluating waste disposition options based on required treatment, waste generation rates, and available/planned commercial treatment. Environmental, Health and Safety (EH\&S), as low as reasonably achievable (ALARA) principles, impact on public/labor relations, and relative cost were accounted for during the evaluation process. 


\subsubsection{Office of River Protection Tank Waste Remediation System Long-Length Equipment Macroencapsulation}

The required treatment for LLE was identified as macroencapsulation followed by disposal in a Hanford Site Subtitle C Landfill. The disposition plan for LLE is based on the baseline assumption that ORP TWRS activities will treat and deliver the LLE in LECs to WMH for disposal. The baseline description is anecdotal, as no programmatic baseline documentation is available at this time. The disposition plan has been confirmed at the project level with ORP TWRS project managers. The plan and facilities are described in Long-Length Contaminated Equipment Disposal Process Path Document, HNF-SD-WM-ER-730.

The planned disposition pathway as described in HNF-SD-WM-ER-730 calls for ORP TWRS to macroencapsulate the LLE at tank farm, under treatment-by-generator provisions. This will be accomplished by first retrieving the LLE from the tank, placing the LLE into a flexible receiver, and tying it off. The packaging and treatment will occur when the waste item is captured by a receiver trailer (HO-64-4283) tilt assembly and transition to the horizontal position, pushing the LLE into the burial container, filling the void space with grout, and sealing the container ends. The macroencapsulated LLE potentially could be RH and there is no provision in the system design to incorporate shielding into the LEC. Accordingly, the LEC will be placed on a shielded transportation trailer (HO-64-4280) and delivered to WMH for disposal. The equipment described is designed, built, and located near the 2704-HV Building ready for use.

Based on the 1998 SWIFTS forecast, generation of LECs was projected to start in FY 1999 and continue through 2028 , with peak generation rates reaching over 2,000 cubic meters per year between FY 2009 to 2014 (refer to Table 3-2, second column). Acquisition of specialized handling equipment could be required to unload and dispose the RH LECs.

\subsubsection{Failed Low-Activity Melters Macroencapsulation and Disposal}

As discussed in Section 3:1, the disposition plan for the failed low-activity melters is under negotiation between $\mathrm{DOE}$ and the privatization contractor. 
Table 3-2. Remote-Handled Low-Level Mixed Waste: Solid Waste Integrated Forecast Technical System Annual Forecast Volumes by Treatment Type (in cubic meters).

\begin{tabular}{|c|c|c|c|c|c|c|}
\hline \multirow{2}{*}{ Calendar Year } & \multirow{2}{*}{$\begin{array}{c}\text { Direct } \\
\text { disposal }\end{array}$} & \multicolumn{2}{|c|}{ Macroencapsulation } & \multirow{2}{*}{$\begin{array}{l}\text { Stabilization/ } \\
\text { neutralization }\end{array}$} & \multirow{2}{*}{$\begin{array}{c}\text { Organic } \\
\text { destruction }\end{array}$} & \multirow{2}{*}{ Total } \\
\hline & & LLE & RH-LLMW & & & \\
\hline 1998 & 0.0 & 0.0 & 39.06 & 3.73 & 0.73 & 44 \\
\hline 1999 & 4.4 & 85.1 & 113.45 & 3.67 & 0.71 & 207 \\
\hline 2000 & 18.8 & 54.3 & 207.16 & 3.72 & 0.71 & 285 \\
\hline 2001 & 14.5 & 699.8 & 210.45 & 3.63 & 0.67 & 929 \\
\hline 2002 & 11.6 & 693.2 & 199.49 & 3.60 & 0.67 & 909 \\
\hline 2003 & 12.9 & 115.2 & 164.66 & 3.61 & 0.67 & 297 \\
\hline 2004 & 12.9 & 663.7 & 154.96 & 3.77 & 0.67 & 836 \\
\hline 2005 & 3.5 & $1,154.5$ & 122.42 & 3.52 & 0.67 & 1,285 \\
\hline 2006 & & 783.4 & 39.75 & 3.48 & 0.67 & 827 \\
\hline 2007 & & $1,083.0$ & 44.51 & 3.48 & 0.67 & 1,132 \\
\hline 2008 & & $1,584.2$ & 57.82 & 3.48 & 0.67 & 1,646 \\
\hline 2009 & & $2,136.3$ & 114.04 & 3.48 & 0.67 & 2,255 \\
\hline 2010 & & $2,108.8$ & 119.78 & 3.48 & 0.67 & 2,233 \\
\hline 2011 & & $2,593.9$ & 123.90 & 0.42 & 0.67 & 2,719 \\
\hline 2012 & & $2,009.6$ & 193.19 & 0.42 & 0.67 & 2,204 \\
\hline 2013 & & $2,676.1$ & 192.03 & 0.42 & 0.67 & 2,869 \\
\hline 2014 & & $2,902.8$ & 214.47 & 0.42 & 0.74 & 3,118 \\
\hline 2015 & & 690.8 & 189.59 & 0.42 & 0.86 & 882 \\
\hline 2016 & & $1,229.2$ & 217.69 & 0.42 & 0.86 & 1,448 \\
\hline 2017 & & 798.5 & 204.64 & 0.42 & 0.86 & 1,004 \\
\hline 2018 & & 152.4 & 162.77 & 0.42 & 0.86 & 316 \\
\hline 2019 & & 196.2 & 34.68 & 0.42 & 0.67 & 232 \\
\hline 2020 & & 196.2 & 33.59 & 0.42 & 0.65 & 231 \\
\hline 2021 & & 214.1 & 33.59 & 0.42 & 0.65 & 249 \\
\hline 2022 & & 98.1 & 27.34 & 0.42 & 0.52 & 126 \\
\hline 2023 & & 98.1 & 27.34 & 0.42 & 0.52 & 126 \\
\hline 2024 & & 98.1 & 27.34 & 0.42 & 0.52 & 126 \\
\hline 2025 & & 98.1 & 28.16 & 0.62 & 0.52 & 127 \\
\hline 2026 & & 98.1 & 28.16 & 0.62 & 0.52 & 127 \\
\hline 2027 & & 98.1 & 28.16 & 0.62 & 0.52 & 127 \\
\hline 2028 & & 98.1 & 28.16 & 0.62 & 0.52 & 127 \\
\hline 2029 & & & 26.93 & 0.31 & 0.52 & 28 \\
\hline 2030 & & & 26.93 & 0.31 & 0.52 & 28 \\
\hline 2031 & & & 26.93 & 0.31 & 0.52 & 28 \\
\hline 2032 & & & 14.08 & 0.31 & 0.26 & 15 \\
\hline 2033 & & & 1.23 & 0.31 & & 2 \\
\hline 2034 & & & 1.23 & 0.31 & & 2 \\
\hline 2035 & & & 1.23 & 0.31 & & 2 \\
\hline Total & 79 & 25,508 & 3,481 & 57 & 22 & 29,148 \\
\hline
\end{tabular}


1

Presently available information indicate that the first forecast for the low-activity melters is due in June 1999, but the total disposal rate is expected to be 10 packages generated over a 10 -year period starting in FY 2007. Each package is expected to weigh 300 metric tons and have a volume of 175 cubic meters, yielding a total life-cycle volume of 1,750 cubic meters that must be accommodated in a new or existing disposal facility. No information currently is available for the high-level melters.

\subsubsection{PUREX Storage Tunnels Waste Disposition}

As discussed in Section 3.1, this PMP does not provide plans for the option of removal and treatment of failed equipment in the PUREX Storage Tunnels. The final disposition plan will be developed as described in Section 3.1.

\subsubsection{Greater Than Category 3 Waste Storage}

Providing storage capacity is the only action required for GTC3 waste under the Tri-Party Agreement. The existing 1.3 cubic meters of GTC3 waste will be stored in CWC until disposal per DOE Orders. No future generation of GTC3 waste is forecast; however, storage capacity in CWC will be available to accommodate this type of waste if the need arises. Once DOE Order 435.1 is issued, an implementation plan will be prepared that addresses GTC3 disposition.

\subsubsection{Commercial Thermal Treatment}

The required treatment for the large container CH LLMW is sorting/repackaging and thermal treatment for organic/carbonaceous and PCB waste. ATG is planning a CTT unit in the Tri-Cities area (Richland, Kennewick, and Pasco) that will accept DOE LLMW and TSCA waste. WMH has a contract with ATG to treat 3,585 cubic meters LLMW (Contract MW6-SBV-357079). As shown in Figure 3-3, the applicable waste volumes are listed for CH LLMW organic/carbonaceous debris and the PCB waste obtained from the sort/repack operation to be sent to ATG for thermal treatment.

\subsubsection{New Treatment Capacity}

The planned actions described previously cover the major portion of the large container CH LLMW, RH LLMW, and all of the GTC3 waste discussed in this M-91-10 PMP. Acquiring new treatment capacity is required to address the remainder of waste discussed in this PMP. The new treatment capacity for these waste streams will include sorting/repackaging and macroencapsulation for the $\mathrm{CH}$ waste (Figure 3-2), and macroencapsulation for the RH debris and homogenous solids contaminated with regulated metals and organics (Figure 3-1). The preferred treatment processes, capabilities, and preliminary design parameters are discussed in the following. 


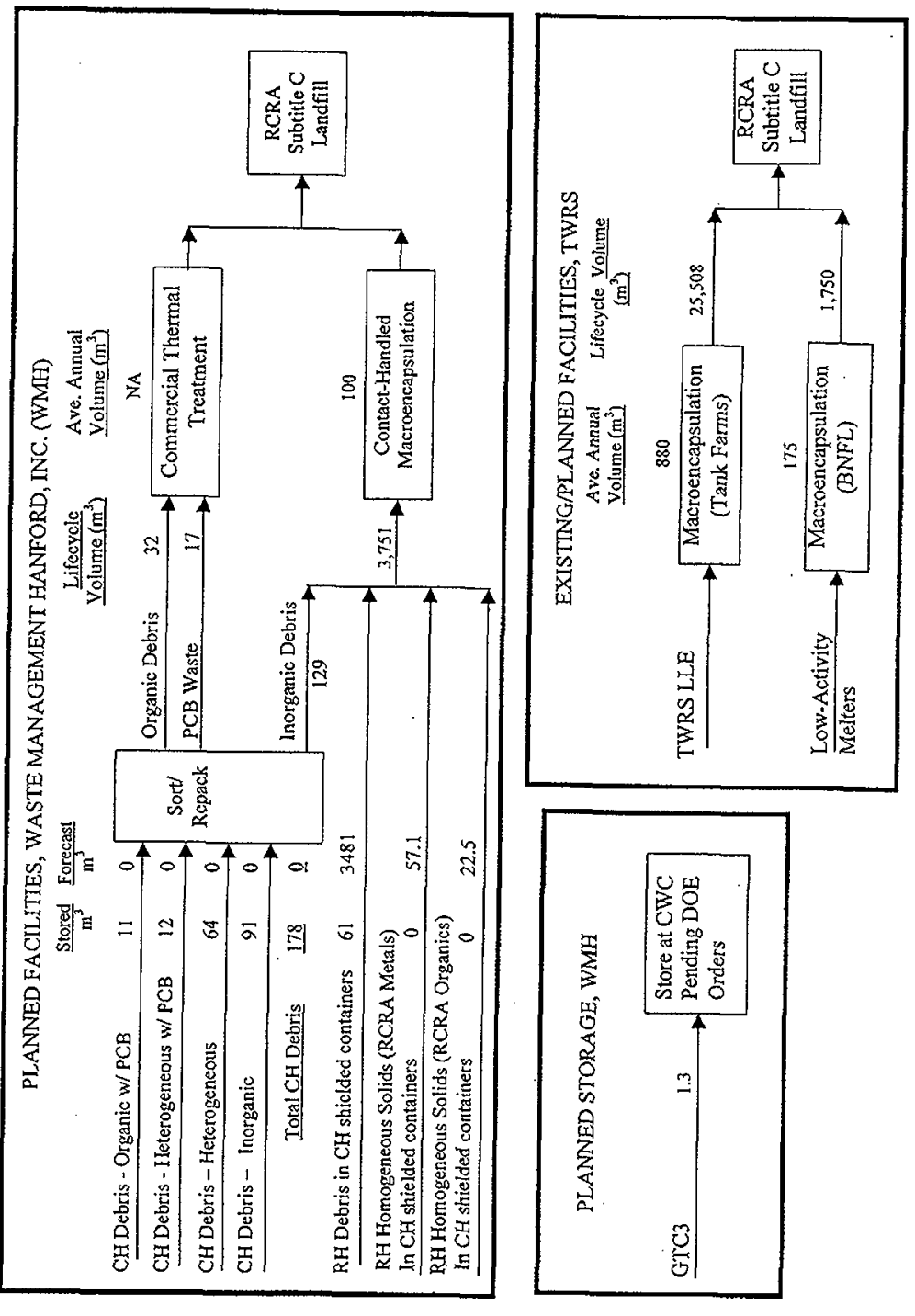

Figure 3-3. Planned Treatment and Storage Facilities for Low-Level Mixed Waste. 
Sort/Repack. A facility will be provided to sort and repackage the large container CH LLMW streams shown in Figure 3-2. The sorting and repackaging operation will be short-term because the process feed stream consists of only 178 cubic meters (12 packages) of stored waste and no future generation is forecast for this waste stream. The facility will have size reduction capabilities for large debris.

Macroencapsulation. Having established separate macroencapsulation pathways for the LLE and the failed low-activity melters, the remaining waste streams that require macroencapsulation are the $\mathrm{RH}$ LLMW debris stream (Figure 3-1), and the 129 cubic meters of stored CH LLMW inorganic debris from the sorting operation (Figure 3-2). The LLE macroencapsulation process cannot be used for this waste because, as discussed previously, the process is designed with special capabilities for bagging long equipment (up to 18 meters long), placing the bagged equipment into a burial container, sealing, and grouting.

Because the stored RH debris (61 cubic meters) was received in shielded $\mathrm{CH}$ containers and future $\mathrm{RH}$ waste will be placed into $\mathrm{CH}$ shielded containers at the point of generation, the $\mathrm{CH}$ shielded containers of RH debris will be macroencapsulated without opening the containers. Such a system will provide for a $\mathrm{CH}$ operation that adheres to the ALARA principles of minimizing personnel exposure risk, enhancing environmental and public protection, while reducing capital and operating costs. The macroencapsulation facility will function for both $\mathrm{CH}$ and shielded RH waste.

The life-cycle forecast volume for RH homogeneous solids and lab packs with regulated metals is 57.2 cubic meters and with regulated organics is 22.4 cubic meters. The annual forecast volumes vary from 0.3 cubic meter to 3.7 cubic meters per year for the waste with regulated metals and 0.3 cubic meter to 0.7 cubic meter per year for the waste with regulated organics. The LDR treatment standards for these waste streams are stabilization/neutralization and organic destruction, respectively. Given these relatively small waste volumes, it is not cost effective to build new facilities to achieve the LDR treatment standard. Without this capacity, this would necessitate the need for long-term storage requiring a waiver, while increasing risk and cost.

Accordingly, it is proposed that these two RH LLMW waste streams alternately be treated via macroencapsulation in $\mathrm{CH}$ shielded containers. Such immobilization technology does not increase the risk to the environment and compares favorably to macroencapsulation of debris contaminated with regulated organics and metals, the LDR treatment standard for these waste streams. This would minimize the EH\&S risks, lessen cost from storage and inspection fees, and decrease overall waste inventory awaiting treatment (Figure 3-3). A waiver for treatability variance via macroencapsulation for these two RH LLMW in CH shielded container waste streams will be submitted for approval once waste is received and the treatment facility has started operating.

Several acceptable methods for performing macroencapsulation could be used. The specific method will be further defined during the conceptual design phase. The method could employ a commercial, off-theshelf technique. Waste packages will be placed into the macroencapsulation overpack (or high-integrity container), packed with fill material to eliminate void space, and sealed. The fill material and the structural integrity of the macroencapsulation container will mitigate concerns for landfill subsidence.

The annual waste feed rate for this process is shown in Table 3-2 and reaches over 190 cubic meters per year between FY 2000 an 2002, and again between 2012 and 2015. The average annual volume to be processed through this facility is only 100 cubic meters per year or 0.4 cubic meter per day (based on 250 operating days per year). 


\subsection{TREATMENT, STORAGE, AND/OR DISPOSAL CAPABILITY}

The TSD pathways for the applicable waste streams have been discussed in the preceding section and are illustrated in Figure 3-3. The TSD pathways include use of.ATG planned CTT and Hanford Site TSD units. The Hanford Site TSD units are expected to allow storage of small volumes of waste in CWC, planned facilities by ORP TWRS, and planned facilities by WMH. The volume and type of waste, in the current inventory and the projected estimates, formed the basis for treatment processes and facility selection. The planned TSD facilities must have the capacity to treat the applicable waste stream volumes and meet the requirements set forth in WAC 173-303. All TSD activities must occur within the boundaries of a permitted TSD facility. The design parameters will be developed further during the conceptual design phases. However, enough information has been developed and presented in the previous sections to warrant setting the following general requirements for the facilities.

\subsubsection{Performance Requirements and Specifications}

The TSD facilities (Figure 3-3) must be designed and built to meet performance and/or permit conditions as set forth in WAC 173-303 and 40 CFR 268. Waivers to specific regulatory requirements, such as the LDR for organic/carbonaceous rule, could be granted by Ecology. Functional and regulatory requirements for the different options are discussed in the following sections.

\subsubsection{Waste Management Federal Services of Hanford, Inc. Planned Facilities}

The sort/repack facility will be designed to handle a total of 178 cubic meters of $\mathrm{CH}$ stored waste consisting of 12 boxes, ranging in weight from 1,091 kilograms to 5,428 kilograms, and in size from 10 cubic meters to 24.6 cubic meters. The facility will be designed to allow for manual operation and will be located inside a contamination control area to contain the potential for the spread of radioactivity. The facility will include material handling equipment to move, open, and empty boxes. Large inorganic debris material that does not fit in standard containers will be reduced mechanically in size using manually operated tools. Sorting devises will be used to segregate organic debris and PCB waste that will be treated thermally in a commercial TSCA-permitted facility. Non-mixed waste, such as uncontaminated packaging, empty containers, and personnel protective equipment (PPE), will be packaged in standard containers and staged for onsite disposal. Repackaged waste will be separated for shipment to the CTT facility or for macroencapsulation.

This sort/repack facility will process 12 individual crates of stored LLMW (another crate containing a drained and rinsed PCB transformer will go directly to a Subtitle C Landfill). The facility will be located at $T$ Plant Complex and fall within the envelope of the existing TSD permit.

The macroencapsulation facility will be designed and built to treat a life-cycle waste volume of 3,751 cubic meters of containerized waste. The facility will accept the following:

- $\mathrm{CH}$ inorganic debris from the sorting operation

- $\mathrm{RH}$ debris (organic and inorganic) packaged in shielded $\mathrm{CH}$ containers

- $\mathrm{RH}$ homogeneous solids with regulated metals and organics packaged in shielded $\mathrm{CH}$ containers.

The macroencapsulation facility must be able to encapsulate different shape containers including boxes and drums. A viable method consists of placing the waste packages into a macroencapsulation overpack, filling the void space with grout or other fill material, and sealing. The encapsulating material and the fill material will be selected to provide structural integrity to the macroencapsulated product so as to 
mitigate concerns for landfill subsidence. The specific macroencapsulation method will be further defined during the technology selection phase. The facility will be located at T Plant Complex and fall within the envelope of existing TSD permit.

The facility will be designed to process approximately 100 cubic meters per year of containerized debris based on one shift per day operation and 250 operating days per year. This throughput corresponds to the approximate average annual volume generation of the applicable waste stream (Table 3-2). At this throughput, the facility could handle the peak annual volume of 219 cubic meters per year (Table 3-2) by operating multiple shifts per day.

\subsubsection{Office of River Protection Existing and Planned Facilities}

LLE Macroencapsulation. As described in Section 3.1, this facility was designed and built to meet ORP TWRS operational and regulatory requirements.

Failed Low-Activity Melters Macroencapsulation. As described in Section 3.1 and 3.4.2, the disposition pathway is being negotiated and is within the purview of the TWRS-P. No information currently is available on high-level melters.

\subsubsection{Commercial Thermal Treatment}

The CTT contract will be used to treat 49 cubic meters of organic/carbonaceous debris and PCB waste from the sorting/repackaging operation of the large container CH LLMW as shown in Figure 3-2. A contract between WMH and the ATG was negotiated for thermal-destructive treatment of CH LLMW including debris, dangerous, and TSCA waste (\#MW6-SBV-357079). The CTT contract requires that ATG begin treating waste by November 2000 . WMH is committed to treating 120 cubic meters per year for 5 consecutive years starting in fiscal year 2001. WMH has the option to treat 597 cubic meters of additional waste in each of the 5 base years. After the 5 base years, WMH has the option to treat up to 310 cubic meters per year for 5 additional years.

\subsection{WORK BREAKDOWN STRUCTURE}

The WBS defines the activities by relating elements of work to each other and the end product. Each element is a discrete portion of hardware, service, or data. Descending levels provide increasing detail and definition of the end objective. The number of levels depends on the scope and complexity of the individual element and the degree of control desired. As described in Section 3.5, the scope includes ORP TWRS existing and TWRS-P planned facilities, WMH planned facilities, and CTT. The need for a WBS and level of WBS for each of the facilities are addressed in the following sections.

\subsubsection{Office of River Protection Tank Waste Remediation System Facilities}

41 The LLE macroencapsulation facility is constructed (Section 3.1). Therefore, no WBS is needed. 


\subsubsection{Tank Waste Remediation System-Privatization Facility}

The generation and subsequent management of the failed low-activity melters will be addressed through interface control document revisions and therefore, no WBS is needed.

\subsubsection{Central Waste Complex Storage}

The latest phase of CWC was built and operations were initiated in June 1997 per Milestone M-91-09 (Project W-112). Waste projections (Figure 3-3) indicate that CWC should have ample storage for the duration of these activities. Because CWC already exists, no WBS needs to be developed.

\subsubsection{Waste Management Federal Services of Hanford, Inc. Planned Facilities}

WMH planned facilities will consist of sorting, repackaging, and size reduction being accomplished in $T$ Plant Complex and macroencapsulation to be performed in an area in the T Plant Complex that falls within the envelope of the TSD permit. No new building will be required and all macroencapsulation handling equipment will be leased from vendors. Premixed grout and other materials will be purchased as necessary, and therefore no grout mixing or pouring equipment will be needed.

Landfill capacity will be planned as part of the overall solid waste management program. However, based on current information, disposal capacity for failed low-activity melters will be addressed separately.

The summary WBS in Figure 3-4 depicts the elements for modification of the existing $T$ Plant Complex as described previously. The top three levels of the WBS depict the elements for standard construction projects. Because these projects relatively will be simple, the WBS level shown is sufficient to carry out all planned activities.

The WBS Dictionary (Appendix C) lists and defines the WBS elements. The Dictionary includes anticipated identification and change and reporting numbers, along with an element task description. As activities proceed, the Dictionary will be updated to reflect current information.

\subsubsection{Commercial Thermal Treatment}

The contract for CTT with ATG is in place (Section 3.4.5) and will initiate thermal treatment of currently stored and newly generated CH LLMW by December 2000 (per Milestone M-91-12). No WBS needs to be developed.

\subsection{INTEGRATION WITH OTHER PROGRAMS}

Interface among the M-91-00 LLMW activities and other onsite programs is essential for successful execution, including waste generating programs for inventory tracking, project planning, and capacity configuration purposes. The M-91-00 LLMW oversight of treatment practices also is required for waste streams that are treated. A brief description of the interface requirements follows. 


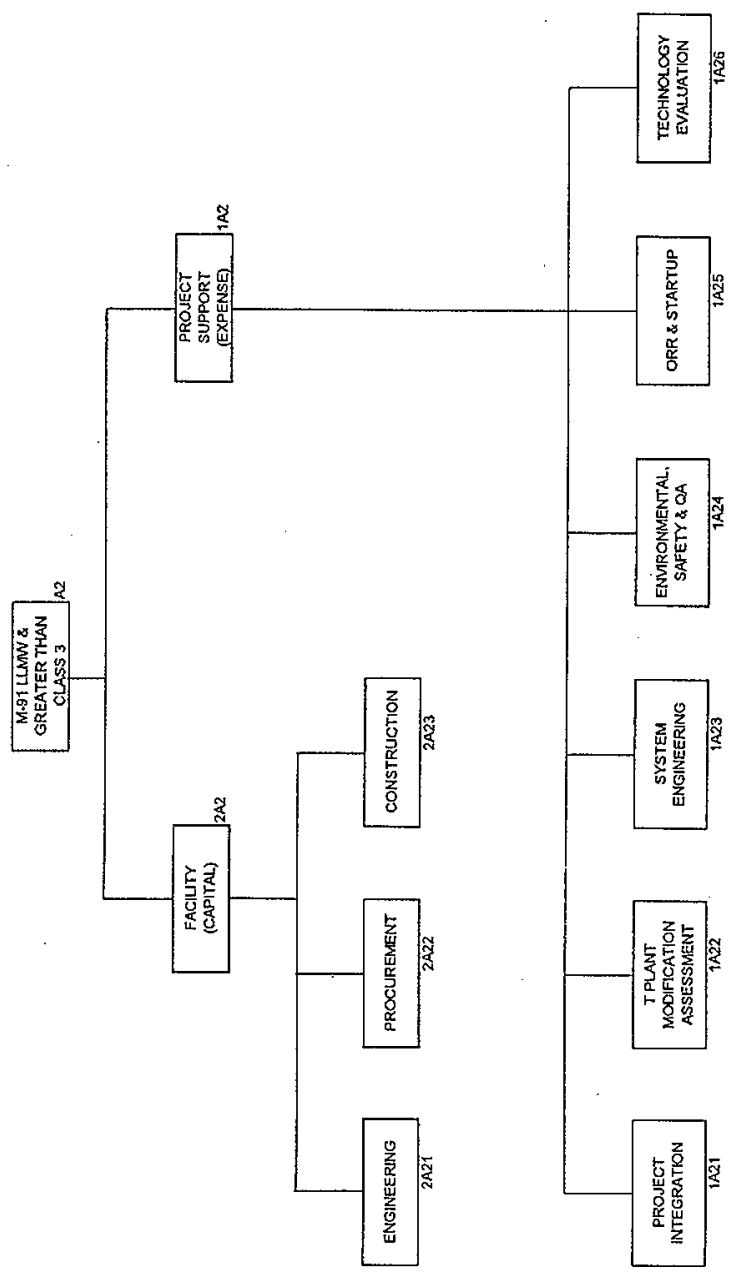

Figure 3-4. Summary Work Breakdown Structure. 
Environmental Impact Statement. The Solid Waste EIS currently is being drafted and will result in the ROD that will cover the M-91-00 LLMW. The Tri-Party Agreement organization will apprise the EIS Project Team on the scope and planning for M-91-00 LLMW treatment options during the draft EIS preparation phase.

Waste Generator Programs. Interface with the generator is conducted through inquiries to the SWIFTS database and direct contact with project managers and/or engineers to ensure that the waste volume forecast continues to support the design capacity of the TSD facilities. The SWIFTS database, described in Section 2.0, is maintained by WMH via interface with waste generators who forecast waste stream volumes and characteristics. Reports generated by the SWIFTS database form the basis for capacity planning for M-91-00 LLMW.

TWRS-P. The TWRS-P will generate and treat most of the waste volume of M-91-00 LLMW. WMH will treat the smaller portion of waste and manage the disposal of all waste. Integration of the two programs is essential to ensure that the TSD capacity is provided for all onsite LLMW streams.

Commercial Thermal Treatment Contract. The CTT contract with ATG will be used to treat repackaged $\mathrm{CH}$ organic/carbonaceous waste. An interface will be maintained with the CTT contract manager to ensure that these waste types are addressed.

Tri-Party Agreement M-19 Projects. Tri-Party Agreement M-19 encompasses the non-thermal treatment and disposal of small container CH LLMW. Some repackaged small containers of LLMW under M-91-00 will be handed-off for subsequent treatment, management, and disposal under M-19. This specific waste stream is anticipated to be produced from sorting and size reduction activities.

Burial Ground Operations. Treated LLMW will be disposed in a Hanford Site Subtitle C Landfill. The M-91-00 LLMW activities will provide sufficient volume forecasts to burial ground operations to allow proper planning, management, and disposal of LLMW. Present annual volume projections for M-91-10 waste streams can be accommodated by existing landfill capacity. Future landfill capacity will be addressed as part of the overall solid waste management program needs. 
4 5

This page intentionally left blank. 
HNF-4293

\subsection{M-91-00 SCHEDULE}

The schedule for the different facilities within the M-91-00 LLMW activities scope is described in the following sections.

\subsection{OFFICE OF RIVER PROTECTION TANK WASTE REMEDIATION SYSTEM FACILITIES}

As described in Section 3.1, the ORP TWRS LLE macroencapsulation facility is constructed. Macroencapsulation of failed low-activity melters, if required, will be covered under TWRS-P. No schedule is needed in this document.

\subsection{CENTRAL WASTE COMPLEX}

The latest phase of CWC was built and operations were initiated in June 1997 per Milestone M-91-09 (Project W-112). The CWC has existing storage capacity for all waste accumulated under M-91-00 LLMW activities and a schedule therefore is not necessary.

\subsection{COMMERCIAL THERMAL TREATMENT}

Contract MW6-SBV-357079 for commercial treatment with ATG is in place and thermal treatment of currently stored and newly generated CH LLMW will be initiated by December 2000 (per M-91-12). Therefore, a schedule is not necessary.

\subsection{WASTE MANAGEMENT FEDERAL SERVICES OF HANFORD, INC. PLANNED FACILITIES}

WMH planned facilities will consist of sorting, repackaging, and size reduction to be accomplished in 2706-T of T Plant Complex (Section 3.5.1.1). Macroencapsulation will be performed on an existing concrete pad in the T Plant Complex area that is within the envelope of the existing TSD permit. The following sections discuss the schedule for this activity.

\subsubsection{Logic-Tied Life-Cycle Schedule}

The project summary schedule is depicted in Table 4-1 and provides major milestones and decision points for the WMH planned facilities acquisition. A more detailed schedule is shown in Figure 4-1. In 1999, the PMP and functional design will be completed. The acquisition phase has a delayed start date of FY 2003 because of funding profile constraints. 
Table 4-1. M-91-00 Summary Schedule.

\begin{tabular}{|c|c|c|}
\hline Project activity & Start & Finish \\
\hline Project management plan & June 1998 & June 1999 \\
\hline Functional design criteria & June 1999 & September 1999 \\
\hline T Plant modification assessment & October 2002 & March 2003 \\
\hline $\begin{array}{c}\text { Technology evaluation/ } \\
\text { budget process }\end{array}$ & January 2003 & December 2003 \\
\hline Equipment specification & January 2004 & March 2004 \\
\hline Equipment procurement & April 2004 & September 2004 \\
\hline Equipment installation & October 2004 & March 2005 \\
\hline Startup & April 2005 & June 2005 \\
\hline
\end{tabular}

2

The T Plant modification assessment consists of evaluating space, utilities, permitting requirements, and EH\&S concerns. The technology evaluation will include the selection of macroencapsulation, sorting, size reduction, repackaging technologies, and preparation of bid specifications. The equipment selection will involve choosing the size, number, specification, and mix of equipment. The equipment procurement will involve the award of contract for the equipment. The equipment installation will include the transport to and setup of the equipment at the site. The startup will be the actual operation of the equipment to demonstrate it will perform as designed.

\subsubsection{Critical Path Analysis}

The critical path for the schedule, as shown in Figure 4-1, is depicted as a hatched line. The functional design criteria (FDC) for this PMP presents no problems as long as funding and approval by Tri-Party Agreement participants occur as needed. The FDC approval in a timely manner will be crucial. The T Plant Complex modification assessment will involve concurrence for proposed use from operations, EH\&S, and other organizations as appropriate. Because the T Plant Complex mission currently is uncertain, these proposed modifications would require a change in mission. The budget outlay is adequate at this time to support the scope, but changes in priorities could affect funding and result in delays. Equipment selection and installation will require review and concurrence such that acquisition could proceed in a timely manner to support startup as scheduled. 

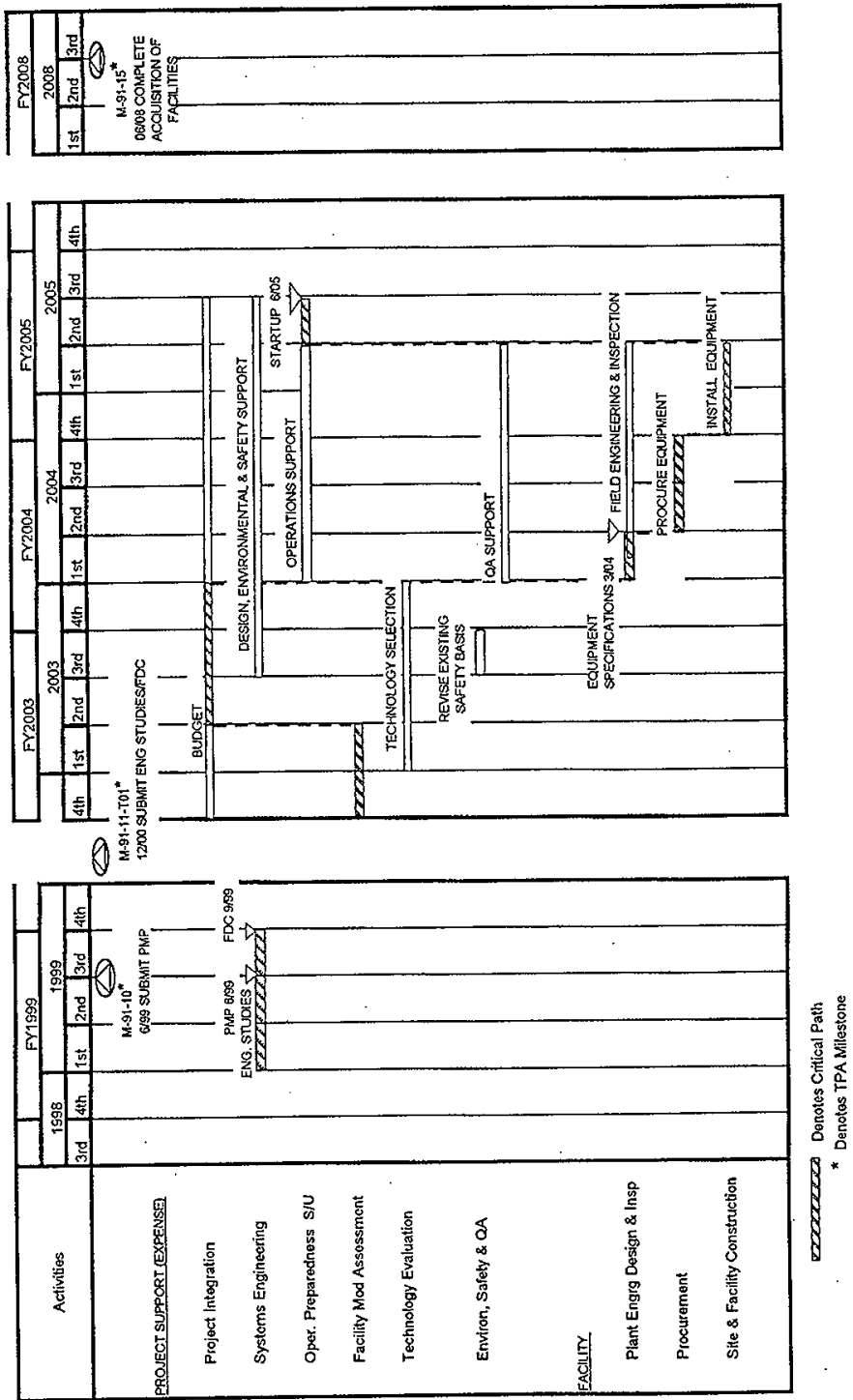

Figure 4-1. Project Summary Schedule. 
HNF-4293

1

2

3

4

This page intentionally left blank. 


\subsection{COST AND RESOURCE PLAN}

2

3

4

5

Budgetary estimates have been developed for Project Capital and Expense planning. The cost details are found in Appendix D. This discussion presents a high-level summary. The funding profile estimates the life-cycle projection of annual funding required in accordance with the summary WBS and schedule. The project will consist of sorting, repackaging, and size reduction being accomplished in 2706-T/TA of $T$ Plant Complex. Macroencapsulation will be performed on an existing concrete pad in the T Plant Complex area and will fall within the envelope of an existing TSD permit. Macroencapsulation equipment will be leased from a vendor. All consumables will be purchased as necessary (such as grout), therefore, no equipment for material preparation is included (e.g., mixers for grout) in this cost estimate.

Table 5-1 shows 1A2 project support engineering and management cost for FY 2003 through 2005. These costs include the $T$ Plant modification assessment, technology evaluation, and $E H \& S$ analysis for $\$ 220 \mathrm{~K}$ in FY 2003; the safety, QA, operational support, and budget preparation for $\$ 120 \mathrm{~K}$ in FY 2004; and the safety QA, and operational startup for $\$ 180 \mathrm{~K}$ in FY 2005 . Facility element 2A2 (Capital) includes the purchase and installation of equipment for size reduction, sorting, and repackaging; and the engineering, procurement, and construction costs of $\$ 580 \mathrm{~K}$ spread from FY 2004 through 2005 . Starting in FY 2005 , the fixed cost of $\$ 2,800 \mathrm{~K}$ per year for $T$ Plant Complex operations will be added into the cost basis for this project; otherwise $T$ Plant Complex would revert to cold standby.

Table 5-1. Total Project Cost (\$K).

\begin{tabular}{|l|c|c|c|c|}
\hline & FY 2003 & FY 2004 & FY 2005 & TOTAL \\
\hline 1A2 Project Support & 220 & 120 & 180 & 520 \\
\hline 2A2 Facility (Capital) & 0 & 480 & 100 & 580 \\
\hline $\begin{array}{l}\text { Total T Plant Complex } \\
\text { Modification }\end{array}$ & 220 & 600 & 280 & 1,100 \\
\hline T Plant Full Operations & N/A & N/A & 2,800 & 2,800 \\
\hline \multicolumn{1}{|c|}{ Total Project } & $\mathbf{2 2 0}$ & $\mathbf{6 0 0}$ & $\mathbf{3 , 0 8 0}$ & $\mathbf{3 , 9 0 0}$ \\
\hline
\end{tabular}

The cost estimate is based on the parametric technique of using information available from other projects similar to the current project scope. As the project proceeds through each phase and more detailed information becomes available, the estimate will evolve to be detail-based. Escalation is applied to the scheduled mid-point of activities for design, inspection, and construction. Contingency guidance for an estimate at this phase ranges from 20 to $30 \%$, and under special conditions, up to $40 \%$. Contingency is evaluated at the lowest level within the cost estimate details and summarized at the upper levels. 
HNF-4293

1
2
3
4
5

This page intentionally left blank. 
HNF-4293

\subsection{M-91-00 CONSTRAINTS}

2 The number, description, and due dates of Tri-Party Agreement milestones associated with TSD of RH

3 LLMW, large container CH LLMW, and storage of GTC3 waste were compared to the M-91-00

4 schedule. The comparison indicates that no conflicts are anticipated and all milestones will be met

5 before the scheduled Tri-Party Agreement due date.

\subsection{WASTE VOLUMES AND TREATMENT CAPACITIES}

Annual and total forecast volumes and waste volumes currently in storage at the Hanford Site (Section 2.0) form the basis for the treatment alternatives and capacities described in this PMP (Section 3.0). There is inherent uncertainty associated with any given waste forecast because the assumptions, goals, and missions driving a waste generator program baseline could change, thereby changing the assumptions that drive the forecast volume estimates. Although uncertainties cannot be entirely eliminated, these are minimized to the extent practicable by validating the SWIFT data through a stringent QA process that includes conducting intensive and extensive peer reviews (Section 2.2). Additionally, the minimum and maximum volume forecasts provided by the waste generators will support facility design considerations to minimize impacts during conceptual design.

A potential impact of these uncertainties is that the planned facility capacities possibly could be over estimated. In this case, the facility might need to be maintained in a standby mode. This scenario most likely would reduce the annual operational costs for a given year, but would increase treatment cost/unit volume.

If the treatment capacity is under estimated, the planned facility would be unable to meet all of the waste processing needs based on a 40 hour per week processing schedule. In this case, the facility could be operated up to 24 hours per day to meet additional processing needs. Increasing facility operation would increase the annual cost of operation and maintenance, but could decrease the cost per unit volume. If treatment capacity is severely under estimated, additional storage space for the waste might need to be provided and/or constructed.

\subsection{COMPLIANCE/PERMIT CONSTRANTS}

As discussed in Section 3.1, the Solid Waste EIS ROD will bound implementation of M-91-00 activities. Regulatory requirements for RCRA permitting and NEPA documentation will be met and are not anticipated to impede the Tri-Party Agreement schedule and fulfillment of M-91-00 LLMW milestones. The ROD could be issued early in calendar year 2000 .

\subsection{FUNDING CONSTRAINTS}

The cost and resource plan, discussed in Section 5.0, provides the estimates to be used for budget requests for M-91-00 LLMW funding. The detailed costs are outlined in Appendix D. At this time, the planned budget might be adequate to carry out all M-91-00 LLMW related activities. Because of funding constraints, the acquisition phase has been delayed until FY 2003. 
1 However, the schedule for performance and completion of the planned activities will slip should funding 2 not be available. Competition for funding among Tri-Party Agreement projects and the long-lead times 3 associated with obtaining an approved budget could impact the schedule for activities. Any significant 4 schedule delay would likely escalate the cost of performing and completing the activities. Substantial 5 schedule delays would increase environmental risk because of the necessity to stockpile waste. 


\subsection{KEY DELIVERABLES}

2 The following key deliverables identify major items that are required for acquiring TSD facilities for RH

3 and large container CH LLMW. These onsite facilities include ORP TWRS, CWC, and modification of 4 existing $\mathrm{T}$ Plant Complex areas, and providing offsite CTT.

- Submit this PMP, which includes all elements as required by Agreement Action Plan, Section 11.5, by June 1999.

- CTT contract agreement \#MW6-SBV-357079 demonstrates capacity for this waste stream. The contract must remain current until compliance is attained.

- Document WMH planned facilities for accomplishing size reduction, sorting, and repackaging as follows.

- FDC: will describe the technical basis for the design of the facility to accomplish size reduction, sorting, and repackaging and will address the scope and design parameters to meet applicable codes and standards.

- Bid specifications: will be prepared for the Request for Proposal to purchase the equipment. This document will describe performance requirements and specifications for the sort/repack process.

- Startup plan: will be written to describe planned activities and procedures required for the initial operation of the unit after installation.

- Acceptance test plan: will describe tests/criteria the equipment must meet before the unit becomes operational. 
HNF-4293

1

2

3

4

5

This page intentionally left blank. 
2 Performance will be measured for PHMC team activities according to the principles of well known

3 project management practices, e.g., cost/schedule control performance criteria, in which work

4 accomplished, schedule, and budget are monitored and reported. Technical performance measurement

5 will be accomplished by a comparison of actual achievement against the technical baseline. An analysis

6 will be performed periodically of the differences between the achievement to date, the current estimate,

7 and the technical baseline, with any new problems and risk areas identified. 
HNF-4293

1

2

3

4

5

This page intentionally left blank. 
HNF-4293

The organization of the agencies, programs, and projects responsible for management and performance of the work described in this PMP are depicted in Figure 9-1.

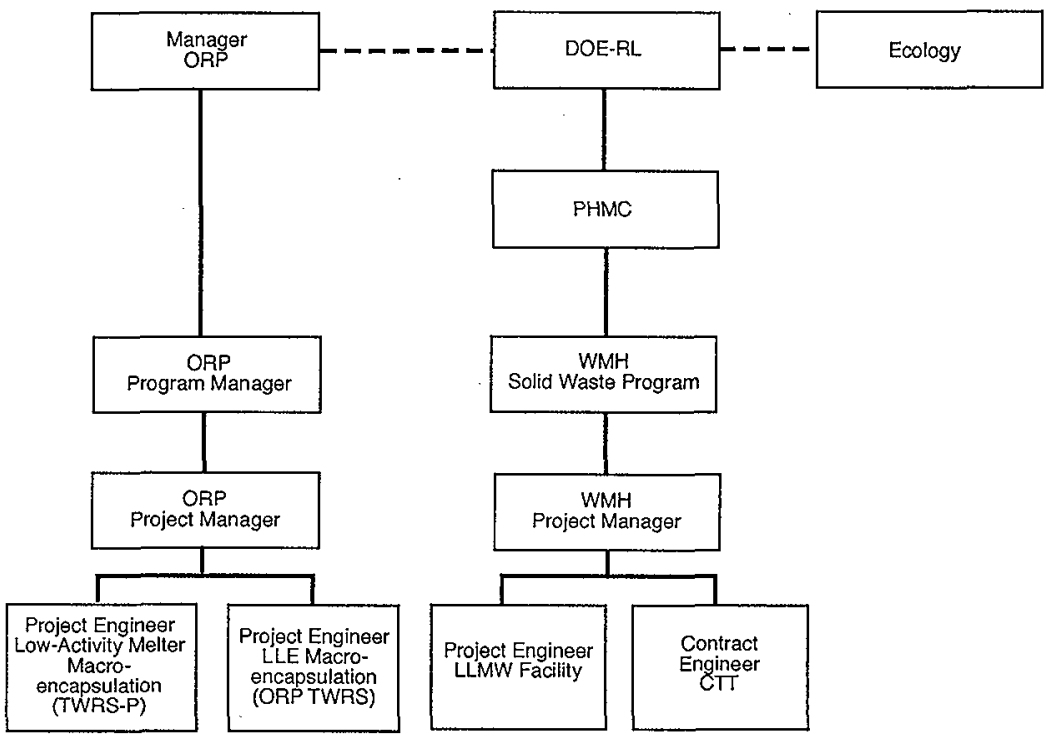

499040025.1

Figure 9-1. Organizational Chart for M-91-10 Project Team.

A comprehensive discussion regarding the roles and responsibilities of the DOE-RL and Ecology project managers is delineated in Section 4.1 of the Tri-Party Agreement as revised in Change Order L-96-01. Project managers for DOE-RL and Ecology are responsible for maintaining contact with the projects and reviewing near-term plans for the projects and milestones. Additionally, DOE-RL is responsible for making funding available and preparing the PHMC Work Authorization.

Fluor Daniel Hanford (FDH) is the coordinating contractor to ensure oversight and integration of WMH projects and other services among PHMC and DOE-RL contractors. FDH also is responsible for preparing project authorization directives and for facilitating funds distribution and management.

The WMH Project Manager is responsible for identifying the scope, schedule, and required budget, and for performing and/or completing the project and tasks delineated in Figure 3.4 and the project schedule (Section 4.0). The WMH Project Manager interfaces with FDH, DOE-RL and Ecology to status progress, address issues, and review near-term plans. The WMH Project Manager also is responsible for project-specific budget management and is accountable for the project engineers performing and supporting the scheduled activities. 
1 The DOE-ORP, is responsible for TWRS-P and ORP TWRS-specific projects.

2

3 Project engineers primarily will be responsible for the technical aspects of a given project and the 4 activities associated with it as delineated in the project schedule.

5

6 
2 System and technical requirements will be made consistent and traceable throughout the WBS as these 3 requirements are developed during the engineering and planning phases of the Project. The control 4 system activities will be compatible with related project management activities.

\subsection{BASELINE CONTROL}

The technical baseline will form the approved and documented technical and functional requirements that must be met. These requirements will be defined further during the engineering phase and formally controlled as the technical baseline. The approved design media (e.g., drawings, specifications, work plans) become the controlling technical documents. Baseline changes are accomplished using formalized PHMC team procedures, requiring approval of change requests. Any change to the estimated cost or schedules must be approved.

\subsection{INTERFACE CONTROL}

17 The change control process requires approval of all impacted contractors. Specific criteria establishing requirements for PHMC team, DOE-RL, and regulator (if appropriate) approval will be developed during planning phases of the project.

\subsection{DOCUMENTATION CONTROL}

Each organization that maintains documents will be required to implement document control in accordance with their QA plan. Copies of project related documents will be sent to the responsible project files organization, in accordance with PHMC team procedures. 
HNF-4293

1

2

3

4

5

This page intentionally left blank. 
HNF-4293

2 A reporting system will be implemented to provide the status relative to meeting all Tri-Party Agreement 3 milestones associated with M-91-10 LLMW and GTC3 waste. The system will maintain a standardized 4 structure to provide adequate comparisons among all facets of the activities, the established schedule, 5 and technical objectives.

6

7

\subsection{NOTIFICATION TO DOE-RL}

Parameters for required notification to DOE-RL will be developed during the planning phases. Terms to be agreed upon could include the following events:

- Advance notice of anticipated schedule slippage

- Baseline changes

- System efficiencies or technical improvements

- Organizational changes.

\subsection{NOTIFICATION TO ECOLOGY}

Notifications to Ecology regarding M-91 Tri-Party Agreement milestones, as described in this PMP, and associated change requests will be performed in accordance with established agreements and procedures. 
HNF-4293

1

2

3

4

This page intentionally left blank. 
HNF-4293

Fiscal year planning under the multi-year work plan (MYWP) will provide the year-to-year control of scope and schedule as allowed by approved FY funding levels. Unless otherwise agreed to by DOE-RL, EPA, and Ecology, MYWPs and sitewide systems engineering control documents must maintain or achieve compliance with afl applicable regulations and Tri-Party Agreement requirements.

Changes to procedures, facility systems, or documentation that support the TSD of M-91-10 LLMW and/or GTC3 waste will be managed in accordance with current PHMC team policies/procedures and reviewed and approved by the appropriate organizations (e:g., management, safety, and quality) before implementation. All approved change documentation will be maintained in accordance with PHMC team record management guidelines.

\subsection{TECHNICAL BASELINE CHANGE CONTROL}

The technical baseline will be defined during the engineering and construction planning phases. A formal change control system will be established in accordance with DOE Orders and onsite procedures to maintain integrated change control.

\subsection{SCHEDULE CHANGE CONTROL}

Required schedule or Tri-Party Agreement milestone revisions are subject to Class 1 change control. The impact of said changes can be readily assessed when a WBS is used, as all start and completion dates for elements are integrated. This allows expedited review and approval by DOE-RL and Ecology of contractor proposed schedule changes.

\subsection{DOCUMENTATION}

A documentation management plan will be established to ensure that documentation is processed in accordance with activity needs and applicable federal, state, and onsite data management requirements.

Baseline Performance Analysis and Reporting provides a basis for the evaluation of execution success and measurement of progress towards the technical, schedule, and cost objectives. The DOE-RL establishes performance measures for assessing subcontractor performance using key work activities that relate to the achievement of the Hanford Site cleanup mission and its continuous improvement process. A hierarchy of control points is established and tied to performance-based contracts that stress cost efficiency and productivity. Earned value methods and best business practices are used to measure performance against the Integrated Site Baseline (ISB).

FDH and DOE-RL jointly participate in the development, execution, and reporting of performance evaluation against the ISB and performance-based subcontracts. This results in awareness, understanding, and ownership of the process by all parties. FDH provides to DOE-RL a monthly report that communicates performance data for the current and cumulative reporting period. The report compares actual performance against planned activities in the ISB. The report includes cost and schedule trends, variance analysis, identification of issues, and planned corrective actions to ensure conformance to the technical, schedule and cost baselines. 
HNF-4293

This page intentionally left blank. 
HNF-4293

\subsection{PROJECT QUALITY ASSURANCE}

The QA discussion within this section pertains to the acquisition/construction of the planned new TSD facilities described in Section 3.0.

\subsection{QUALITY ASSURANCE POLICY}

HNF-POL-QA, Quality Assurance Policy governs all work performed onsite by PHMC contractors and ensures that such work is accomplished in a manner protective of human health and safety with a high level of quality and in a cost-effective manner. Quality is carried through each level of management through project implementation plans and procedures, and is verified by assessment and continuous improvement programs. Quality and safety concerns can be communicated to the highest level of management, regardless of the contractor or subcontractor organization performing the work. Work performed on the M-91-00 activities will conform to the requirements set forth in 10 CFR 830.120, Quality Assurance Requirements, and DOE Order $5700.6 \mathrm{C}$, Quality Assurance. The requirements of ANSI/ASME Standard NQA-1 are effectively met by the application of the criteria in the DOE Order.

\subsection{QUALITY ASSURANCE MANAGEMENT}

The overall guiding QA plan governing work by PHMC contractors is HNF-MP-014: Quality Assurance Plan. Objectives of the plan are to ensure the following actions are incorporated in every process, including design and construction activities:

- Senior management provides planning, organization, direction, control, and support to achieve quality objectives

- Subcontractors achieve and adhere to quality requirements

- Overall performance is reviewed and evaluated using a rigorous assessment program.

\subsection{PERFORMANCE}

\section{Quality Assurance Program Plans.}

The M-91-00 activities will implement the QA Policy and management of the requirements set forth in $10 \mathrm{CFR} 830.120$ and DOE Order $5700.6 \mathrm{C}$ (which basically iterates the requirements of $10 \mathrm{CFR} 830.120$, and meets the intent of NQA-1). An appropriate quality assurance program plan (QAPP) will be developed to define the organizational structure, functional responsibilities, levels of authority, and interfaces for those managing, performing and assessing work. The appropriate application of the 10 prescribed criteria mandated in the DOE Order will be defined. Contractor-level QAPPs, and subtier QAPPs as needed, will be developed to complete the definition of the QA program implementation.

\section{Quality Assurance Program Implementation Plan for Nuclear Facilities.}

In compliance to 10 CFR 830.120 , the status of M-91-00 nuclear facility implementation activities, including the status of action items, will be documented per requirements in the Project Hanford Quality Assurance Program Implementation Plan for Nuclear Facilities (HNF-SP-1228). 
Implementing Procedures.

QA procedures for internal use among the contractors or subcontractors performing work will be developed in accordance to the requirement of the guiding QA Program. Work control documents, e.g., those used to control the content and implementation of work packages for specific work scope, will be developed.

\subsection{ASSESSMENTS}

9 The audit and assessment program is to be implemented by the cognizant first-tier contractor (i.e., $10 \mathrm{WMH}$ ) and coordinated by each subcontractor. Independent audits and surveillance will be performed 11 using QA procedures, and internal assessments will be performed to provide indication of progress of 12 continuous improvement programs.

\subsection{TRAINING AND QUALIFICATIONS}

Training and qualification programs will be established and implemented by the cognizant contractor and subcontractors to satisfy the requirements of 10 CFR 830.120 (c)(1)(ii), Personnel Training and Qualifications, and DOE Order 5700.6C (9)(b)(1)(b), Criterion-Personnel Training and Qualifications.

\subsection{AUTHORITY}

All personnel have authority to stop work on any activity they view as an imminent hazard to the safety or health of personnel, the public, or to the environment. The quality management system will provide a process for escalating quality concerns through the line organizations and, if necessary, to the integrating contractor, FDH/Vice President-QA, who has the authority to stop work on any activity where a significant quality problem exists. In such cases, work only can be resumed after review and approval by the FDH/Vice President-QA or the FDH/President. 
2 The DOE-RL and Hanford Site contractor policy is to conduct its operations in an environmentally safe

3 and sound manner. Protection of the environment and the public are responsibilities of paramount

4 importance and concern, and all activities should recognize and reflect this public trust. To that end, the

5 PHMC contractors are firmly committed to ensuring incorporation of national environmental protection

6 goals in the formulation and implementation of the M-91-00 activities. Operations will be conducted in

7 compliance with the letter and spirit of applicable environmental statutes, regulations, and standards.

To ensure that the actions called for in M-91-00 comply with applicable environmental requirements, NEPA, and DOE policy, the following will be performed.

- Issue and update, as required, a general EIS that reflects the DOE and Hanford Site environmental policy and contains broad environmental protection goals.

- All required environmental permits will be secured from the appropriate regulatory agency in a timely manner. Consistent with the Tri-Party Agreement, consent decrees, or other legal or administrative documents, permit requirements and conditions will reflect the requirements of environmental regulations, consistent with national security interests.

- Establish and maintain liaison and cooperative programs with appropriate federal, state, and local officials to facilitate effective environmental management.

- Ensure that budget requests provide for required environmental protection upgrades and corrective action, that these are timely, and that these are consistent with pollution abatement plans prepared as required.

- Provide for community public information and education programs concerning DOE environmental protection programs, consistent with the requirements of environmental regulations and national security interests.

A determination that an environmental assessment or an EIS is appropriate or required will be made during the early stages of project development. It is anticipated that the actions called for in this PMP will be covered by the existing EIS. NEPA milestones will be incorporated, as appropriate, in project planning documents. 
HNF-4293

1

2

3

4

5

This page intentionally left blank. 


\subsection{HEALTH AND SAFETY}

2 The Integrated Safety Management System (ISMS) establishes a single, defined safety and

3 environmental system that integrates EH\&S requirements into the work planning and execution

4 processes to effectively protect the public, personnel, and the environment. The ISMS encompasses the

5 entire set of practices used to ensure safety onsite, extending to coverage implied by the term 'safety

6 culture'. ISMS presents a system view of a standards-based safety management program and assists in

7 achieving EH\&S goals. 
HNF-4293

1

2

3

4

This page intentionally left blank. 
HNF-4293

\subsection{REFERENCES}

DOE Order 5700.6C, "Quality Assurance".

DOE/EA-1135, Environmental Assessment for Offsite Thermal Treatment of Low-Level Mixed Waste.

DOE/LLW-217, DOE Waste Treatability Group Guidance Document.

DOE/RL-88-21, Hanford Facility Dangerous Waste part A Permit Application.

DOE/RL-98-09, 1998 Report on Franford Site Land Disposal Restrictions for Mixed Waste.

Ecology, EPA, and DOE-RL, 1999, Hanford Federal Facility Agreement and Consent Order.

HNF-2063, Trade Study for Processing, Treatment, and Storage of Hanford Site Solid Waste Streams That Have No Current Path Forward.

HNF-EP-0063, Hanford Site Waste Acceptance Criteria.

HNF-EP-0918, Rev. 4, Solid Waste Integration Forecast Technical Report.

HNF-MP-014, Quality Assurance Plan.

HNF-POL-QA, Quality Assurance Policy.

HNF-SD-WM-ER-730, Long-Length Contaminated Equipment Disposal Process Path Document.

HNF-SP-1210, Interface Control Document Between DOE and BNFL, ICD03, Rev. 1.

HNF-SP-1228, Project Hanford Quality Assurance Program Implementation Plan for Nuclear Facilities.

WHC-SD-WM-ES-341, Solid Waste and Materials System Alternatives Study, June 1995. 


\section{HNF-4293}

1

2

3

4

5

6

This page intentionally left blank. 
HNF-4293 
1

2

3

4

5

No new relevant milestones were identified and therefore no Change Request Form is provided. 
HNF-4293

1

2

APPENDIX B

LOW-LEVEL MIXED WASTE DATA 
HNF-4293

This page intentionally left blank. 


\section{STORED}

\section{Large Containers CH LLMW}


恿 000000000

崖

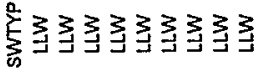

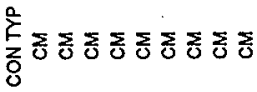

牙 $8088 \times 8888$

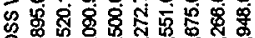

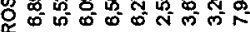

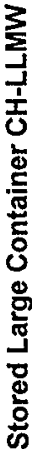

$\mathbb{0}$

$\sum_{\frac{5}{5}}^{\frac{L}{5}}$

$\sum_{\frac{1}{2}}^{0} \sum \frac{0}{\alpha} \propto \propto \frac{0}{\alpha 2} \frac{0}{\Sigma} \Sigma \Sigma \Sigma$

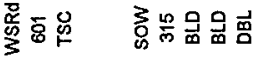

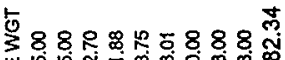

แ约 숭

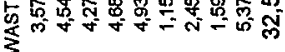

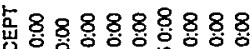

잉

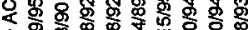

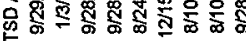

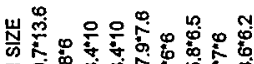

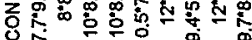

$0 \neq-0$ क

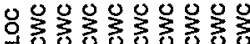

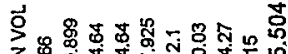

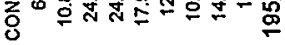

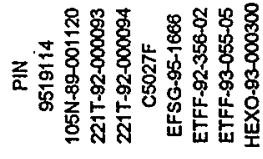




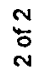
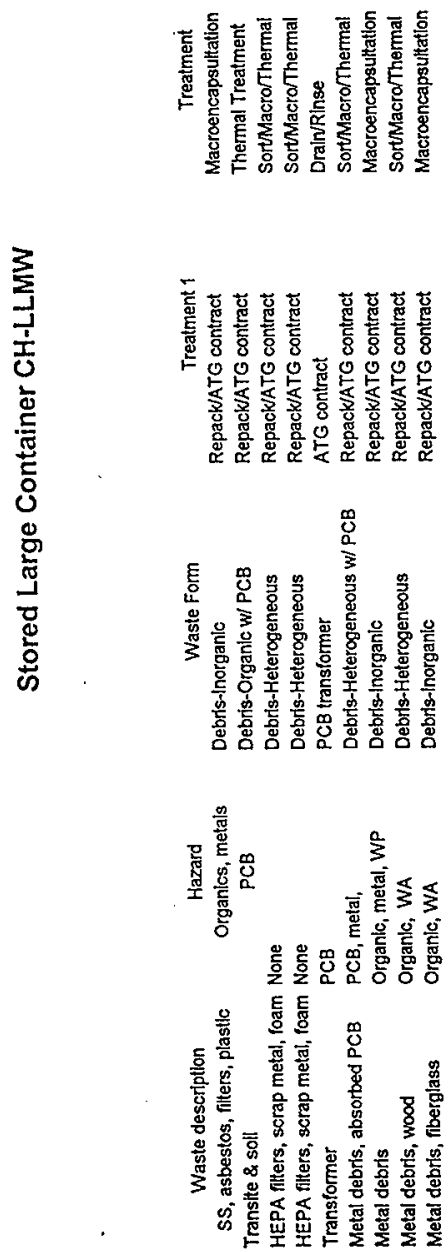


\section{STORED RH LLMW}


崖

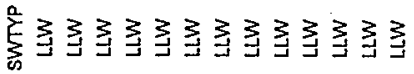

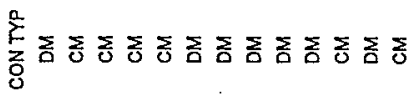

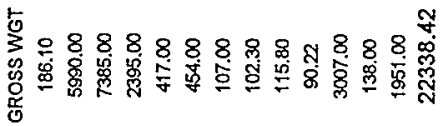

宸

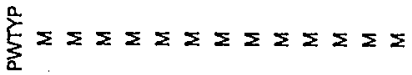

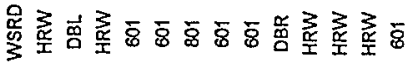

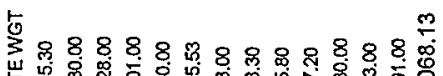

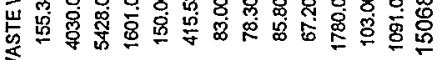
3

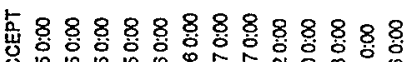

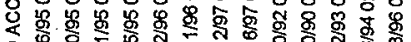

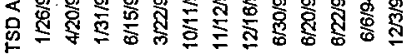

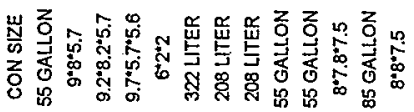

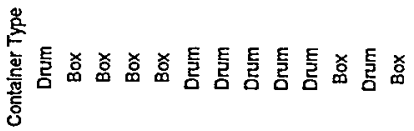

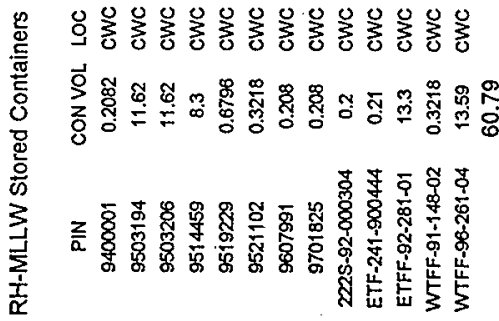


0
0
0
0

0
0
0
0
0
0

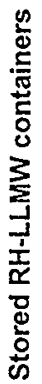
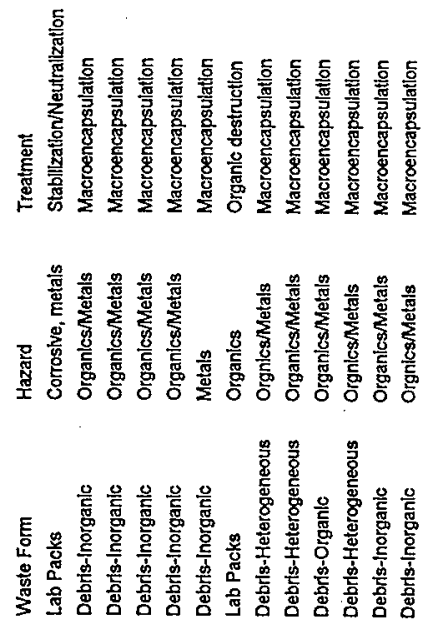

志

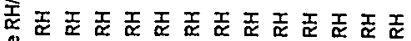

密

동

壱 0000000000000

亏ั 


\section{FORECAST RH LLMW}


曷

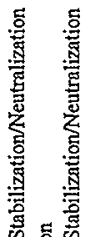

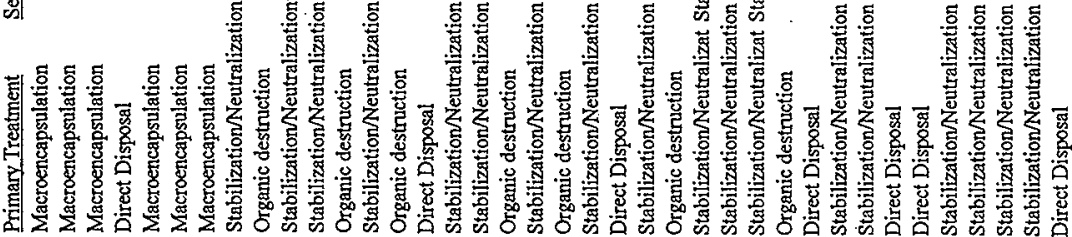

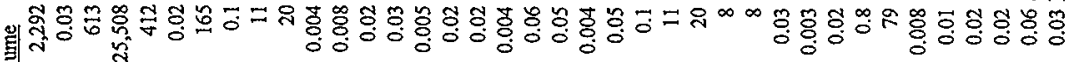

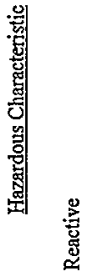

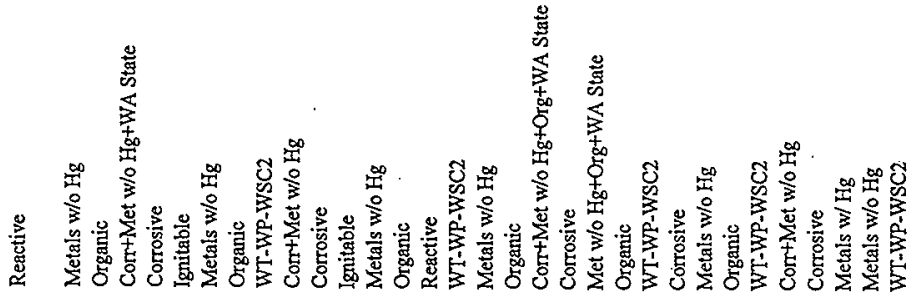

害

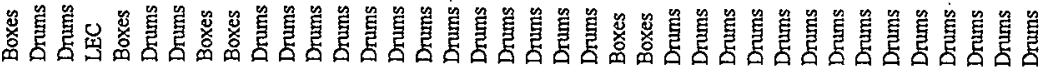

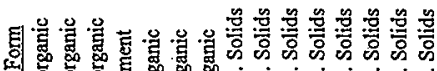

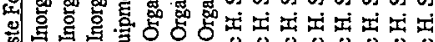

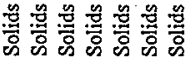

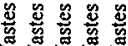

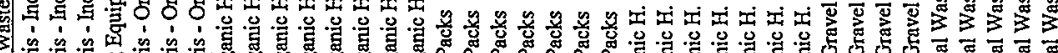

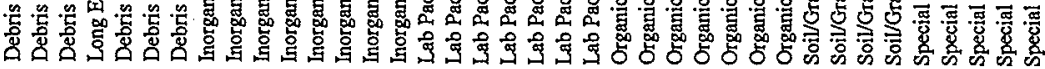

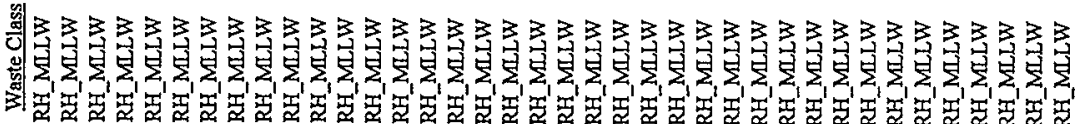




\begin{tabular}{|c|c|c|c|c|c|}
\hline Wastc Class & Waste Form & Container & Hazardous Characteristic & YEAR & Volume Treatment \\
\hline RH_MLLW & Debris-Inorganic & Boxes & & 1998 & 21 Macroencapsulation \\
\hline RH_MLLW & Debris - Inorganic & Boxes & & 1999 & 80 Macroencapsulation \\
\hline RH_MLLW & Debris - Inorganic & Boxes & & 2000 & 119 Macroencapsulation \\
\hline RH_MLLW & Debris - Inorganic & Boxes & & 2001 & 139 Macroencapsulation \\
\hline $\mathrm{RH}$ MLLW & Debris - Inorganic & Boxes & & 2002 & 139 Macroencepsulation \\
\hline RH_MLLW & Debris - Inorganic & Boxes & & 2003 & 100 Macroencapsulation \\
\hline RHI_MLLW. & Debris - Inorganic & Boxes & & 2004 & 80 Macroencapsulation \\
\hline RH_MLLW & Debris - Inorganic & Boxes & & 2005 & 80 Macroencapsulation \\
\hline RH_MLLW & Debris - Inorganic & Boxes & & 2006 & 21 Macroencapsulation \\
\hline RH_MLLW & Debris - Inorganic & Boxes & & 2007 & 21 Macroencapsulation \\
\hline RUIMLLW & Debris - Inorganic & Boxes & & 2008 & 21 Macroencapsulation \\
\hline RH_MLLW & Debris - Inorganic & Boxes & & 2009 & 80 Macroencapsulation \\
\hline RHE_MLLW & Debris - Inorganic & Boxes & & 2010 & 80 Macrocncapsulation \\
\hline RH_MLLW & Debris - Inorganic & Boxes & & 2011 & 80 Macroencipsulation \\
\hline RH_MLLW & Debris - Inorganic & Boxes & & 2012 & 139 Macroencapsulation \\
\hline RH_MLLW & Debris - Inorganic & Boxes & & 2013 & 139 Macroencapsulation \\
\hline RH_MLLW & Debris - Inorganic & Boxes & & 2014 & 141 Macroencapsulation \\
\hline RH_MLLW & Debris - Inorganic & Boxes & & 2015 & 145 Macroencapsulation \\
\hline RH_MLLW & Debris - Inorganic & Boxes & & 2016 & 145 Macroencapsulation \\
\hline RH_MLLW & Debris - Inorganic & Boxes & & 2017 & 145 Macroencapsulation \\
\hline RH_MLLW & Debris - Inorganic & Boxes & & 2018 & 145 Macroencapsulation \\
\hline RH_MLLW & Debris - Inorganic & Boxes & & 2019 & 21 Macroencapsulation \\
\hline RH_MLLW & Debris - Inorganic & Boxes & & 2020 & 20 Mecroencapsulation \\
\hline RH_MLLW & Debris - Inorganic & Boxes & & 2021 & 20 Macroencapsulation \\
\hline RH_MLLW & Debris - Inorganic & Boxes & & 2022 & 16 Macroencapsulation \\
\hline RH_MLLW & Debris - Inorganic & Boxes & & 2023 & 16 Macroencapsulation \\
\hline RH_MLLW & Debris - Inorganic & Boxes & & 2024 & 16 Macroencapsulation \\
\hline RH_MLLW & Debris - Inorganic & Boxes & & 2025 & 16 Macroencapsulation \\
\hline RH MLLW. & Debris - Inorganic & Boxes & & 2026 & 16 Macrocncapsulation \\
\hline RH_MLLW & Debris - Inorganic & Boxes & & 2027 & 16 Macroencapsulation \\
\hline RH_MLLW & Debris - Inorganic & Boxes & & 2028 & 16 Macroencapsulation \\
\hline $\mathrm{RH}_{-} \mathrm{MLLW}$ & Debris - Inorganic & Boxes & & 2029 & 16 Macroencapsulation \\
\hline RH_MLLW & Debris - Inorganic & Boxes & & 2030 & 16 Macroencapsulation \\
\hline RH_MLLW & Debris - Inorganic & Boxes & & 2031 & 16 Macroencapsulation \\
\hline RH_MLLW & Debris - Inorganic & Boxes & & 2032 & 8 Macroencapsulation \\
\hline RH_MLLW & Debris - Inorganic & Drums & Reactive & 1998 & 0.009 Macroencapsulation \\
\hline RH_MLLW & Debris - Inotganic & Drums & Reactive & 1999 & 0.009 Macroencapsulation \\
\hline RH_MLLW & Debris - Inorganic & Drums & Reactive & 2000 & 0.009 Macroencapsulation \\
\hline RH_MLLW & Debris - Inorganic & Drums & & 1998 & 3 Macroencapsulation \\
\hline RH_MLLW & Debris - Inorganic & Drums & & 1999 & 13 Macroencapsulation \\
\hline RH_MLLW & Debris - Inorganic & Drims & & 2000 & 44 Macroencapsulation \\
\hline $\mathrm{RH}$ _MLLW & Debris - Inorganic & Drums & & 2001 & 34 Macroencapsulation \\
\hline RH_MLLW & Debris - Inorganic & Drums & & 2002 & 28 Macroencapstalation \\
\hline RH_MLLW & Debris - Inorganic & Drums & · & 2003 & 31 Macroencapsulation \\
\hline RH_MLLW & Debris - Inorganic & Drums & & 2004 & 41 Macroencapsulation \\
\hline RH_MLLW & Debris - Inorganic & Drums & & 2005 & 23 Macroencapsulation \\
\hline RH_MLLW & Debris - Inorganic & Drums & & 2006 & 6 Macroencapsulation \\
\hline RH_MLLW & Debris - Inorganic & Drums & & 2007 & 11 Macroencapsulation \\
\hline RH_MLLW & Debris - Inorganic & Drums & & 2008 & 24 Macroencspsulation \\
\hline RH_MLLW & Debris - Inorganic & Drums & & 2009 & 21 Macroencapsulation \\
\hline RH_MLLW & Debris - Inorganic & Drums & & 2010 & 27 Macroencapsulation \\
\hline RH_MLLW & Debris - Inorganic & Drums & & 2011 & 31 Macroencapsulation \\
\hline RH_MLLW & Debris - Inorganic & Drums & & 2012 & 41 Macroencspsulation \\
\hline RH_MLLW & Debris - Inorganic & Drums & & 2013 & 40 Macroencapsulation \\
\hline RH_MLLW & Debris - Inorganic & Drums & & 2014 & 59 Macrocncapsulation \\
\hline RH_MLLW & Debris - Inorganic & Drums & & 2015 & 28 Macroencapsulation \\
\hline RH_MLLW & Debris - Inorganic & Drums & & 2016 & 56 Macroencapsulation \\
\hline RH_MLLW & Debris - Inorganic & Drums & & 2017 & 43 Macroencapsulation \\
\hline
\end{tabular}




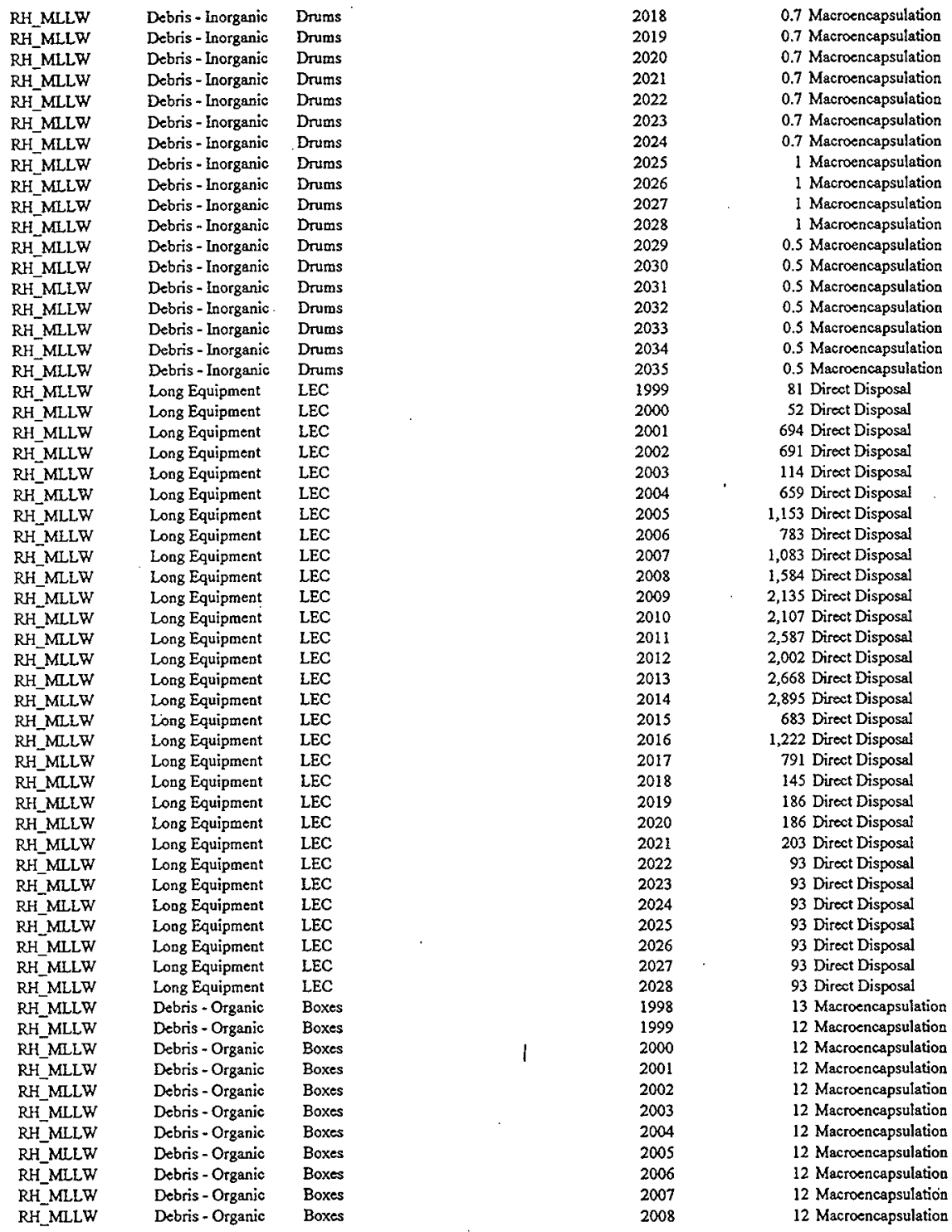




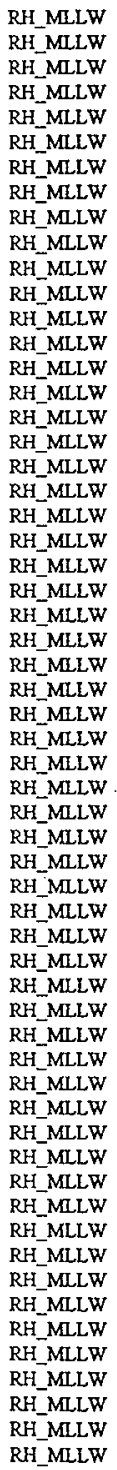

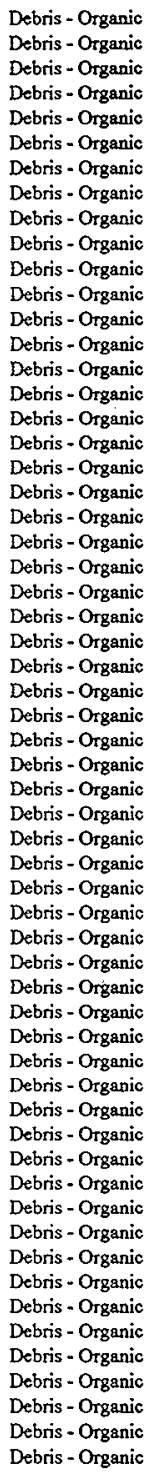

Boxes

Boxes

Boxes

Boxes

Boxes

Boxes

Boxes

Boxes

Boxes

Boxes

Boxes

Boxes

Boxes

Boxes

Boxes

Boxes

Boxes

Boxes

Boxes

Boxes

Boxes

Boxes

Boxes

Boxes

Drums

Drums

Drums

Drums

Drums

Drums

Drums

Drums

Drums

Drums

Drums

Drums

Drums

Drums

Drums

Drums

Drums

Drums

Drums

Drums

Drums

Drums

Drums

Drums

Drums

Drums

Drums

Drums

Drums

Drums

Drums

Drums

Drums

Drums

Drums
12 Macroencapsulation

12 Macrocncepsulation

12 Macroencapsulation

12 Macroencapsulation

12 Macroencapsulation

14 Macroencapsulation

16 Macrocncapsulation

16 Macroencapsulation

16 Macrocncapsulation 16 Macroencapsulation 12 Macroencapsulation 12 Macroencapsulation 12 Macroencapsulation 10 Macroencapsulation 10 Macroencapsulation 10 Macroencapsulation 10 Macroencapsulation 10 Macroencapsulation 10 Macroencapsulation 10 Macroencapsulation 10 Macroencapsulation 10 Macroencapsulation 10 Macroencapsulation

5 Macroencapsulation 0.005 Macroencapsulation 0.005 Macroencapsulation 0.005 Macroencapsulation

1 Macroencapsulation

8 Macroencapsulation

32 Macroencapsulation 25 Macroencapsulation 20 Macrocncapsulation 22 Macroencapsulation 22 Macroencapsulation

7 Macroencapsulation 0.9 Macroencapsulation 0.9 Macroencapsulation 0.9 Macroencapsulation 0.9 Macroencapsulation 0.9 Macroencapsulation 0.9 Macroencapsulation 0.9 Macroencapsulation 0.9 Macroencapsulation 0.9 Macroencapsulation 0.9 Macroencapsulation 0.9 Macroencapsulation 0.9 Macroencapsulation 0.9 Macroencapsulation 0.9 Macroencapsulation 0.9 Macroencapsulation 0.9 Macroencapsulation 0.9 Macroencapsulation 0.9 Macroencapsulation 0.9 Macroencapsulation 1 Macroencapsulation 1 Macroencapsulation 1 Macroencapsulation 1 Macroencapsulation 0.7 Macroencapsulation 


\begin{tabular}{|c|c|c|c|c|}
\hline RH_MLLW & Lab Packs & Drums & Organic & 2000 \\
\hline RH_MLLW & Lab Packs & Drums & Reactive & 1998 \\
\hline RH_MLLW & Lab Packs & Drums & Reactive & 1999 \\
\hline RH_MLLW & Lab Packs & Drums & Reactive & 2000 \\
\hline RH_MLLW & Lab Packs & Drums & WT-WP-WSC2 & 1998 \\
\hline RH_MLLW & Lab Packs & Drums & WT-WP-WSC2 & 1999 \\
\hline RH_MLLW & Lab Packs & Drurns & WT-WP-WSC2 & 2000 \\
\hline RH_MLLW & Lab Packs & Drums & WT-WP-WSC2 & 2004 \\
\hline RH_MLLW. & Organic H. Solids & Boxes & Metals w/o Hg & 1998 \\
\hline RH_MLLW & Organic H. Solids & Boxes & Metals w/o Hg & 1999 \\
\hline RH_MLLW & Organic H. Solids & Boxes & Metals w/o Hg & 2000 \\
\hline RH_MLLW & Organic H. Solids & Boxes & Metals w/o Hg & 2001 \\
\hline RH_MLLW & Otganic H. Solids & Boxes & Metals w/o Hg & 2002 \\
\hline $\mathrm{RH}_{-}^{-} \mathrm{MLLW}$ & Otganic H. Solids & Boxes & Metals w/o Hg & 2003 \\
\hline RH_MLLW & Organic H. Solids & Boxes & Metals w/o $\mathrm{Hg}$ & 2004 \\
\hline RH_MLLW & Organic H. Solids & Boxes & Metals w/o Hg & 2005 \\
\hline RH_MLLW & Organic H. Solids & Boxes & Metals w/o $\mathrm{Hg}$ & 2006 \\
\hline $\mathrm{RH}_{-} \mathrm{MLLW}$ & Otganic H. Solids & Boxes & Metals w/o Hg & 2007 \\
\hline RH_MLLW & Organic H. Solids & Boxes & Metals w/o $\mathrm{Hg}$ & 2008 \\
\hline RH_MLLW & Otganic H. Solids & Boxes & Metals w/o Hg & 2009 \\
\hline RH_MLLW & Organic H. Solids & Boxes & Metals w/o $\mathrm{Hg}_{\mathrm{g}}$ & 2010 \\
\hline RH_MLLW & Organic H. Solids & Boxes & Metals w/o $\mathrm{Hg}$ & 2011 \\
\hline RH_MLLW & Organic H. Solids & Boxes & Metals w/o Hg & 2012 \\
\hline RH_MLLW & Organic $\mathrm{H}$. Solids & Boxes & Metals w/o Hg & 2013 \\
\hline RH_MLLW & Organic H. Solids & Boxes & Metals w/o Hz & 2014 \\
\hline $\mathrm{RH}_{-} \mathrm{MLLW}$ & Organic H. Solids & Boxes & Metals w/o Hg & 2015 \\
\hline $\mathrm{RH}_{-} \mathrm{MLLW}$ & Organic H. Solids & Boxes & Metals w/o Hg & 2016 \\
\hline RH_MLLW & Organic $\mathrm{H}$. Solids & Boxes & Metals w/o Hg & 2017 \\
\hline RH_MLLW & Organic H. Solids & Boxes & Metals w/o Hg & 2018 \\
\hline $\mathrm{RH}_{-} \mathrm{MLLW}$ & Organic H. Solids & Boxes & Metals w/o Hg & 2019 \\
\hline RH_MLLW & Organic $H$. Solids & Boxes & Metals w/o Hg & 2020 \\
\hline RH_MLLW & Organic HI. Solids & Boxes & Metsls w/o Hg & 2021 \\
\hline RH_MLLW & Organic H. Solids & Boxes & Metals w/o Hg & 2022 \\
\hline RH_MLLW & Otganic H. Solids & Boxes & Metals w/o Hg & 2023 \\
\hline $\mathrm{RH}_{-} \mathrm{MLLW}$ & Organic H. Solids & Boxes & Metals w/o Hg & 2024 \\
\hline RH_MLLW & Organic $\mathrm{H}$. Solids & Boxes & Metals w/o Hg & 2025 \\
\hline RH_MLLW & Organic $H$. Solids & Boxes & Metals w/o Hg & 2026 \\
\hline RH_MLLW & Organic H. Solids & Boxes & Metals w/o Hg & 2027 \\
\hline $\mathrm{RH} \_\mathrm{MLLW}$ & Organic H. Solids & Boxes & Metals w/o Hg & 2028 \\
\hline RH_MLLW & Organic H. Solids & Boxes & Metals w/o Hg & 2029 \\
\hline RH_MLLW & Organic H. Solids & Boxes & Metals w/o Hg & 2030 \\
\hline RH_MLLW & Organic H. Solids & Boxes & Metals w/o Hg & 2031 \\
\hline RH_MLLW & Organic H. Solids & Boxes & Metals w/o Hg & 2032 \\
\hline RH_MLLW & Organic H. Solids & Boxes & Organic & 1998 \\
\hline RH_MLLW & Organic H. Solids & Boxes & Organic & 1999 \\
\hline RH_MLLW & Organic $H$. Solids & Boxes & Otganic & 2000 \\
\hline RH_MLLW & Organic H. Solids & Boxes & Organic & 2001 \\
\hline RH_MLLW & Organic H. Solids & Boxes & Organic & 2002 \\
\hline RH_MLLW & Organic H. Solids & Boxes & Organic & 2003 \\
\hline RH_MLLW & Organic H. Solids & Boxes & Organic & 2004 \\
\hline RH_MLLW & Organic H. Solids & Boxes & Organic & 2005 \\
\hline RH_MLLW & Organic H. Solids & Boxes & Organic & 2006 \\
\hline RH_MLLW & Organic H. Solids & Boxes & Organic & 2007 \\
\hline RH_MLLW & Organic H. Solids & Boxes & Organic & 2008 \\
\hline $\mathrm{RH} \_\mathrm{MLLW}$ & Organic H. Solids & Boxes & Organic & 2009 \\
\hline RH_MLLW & Organic H. Solids & Boxes & Organic & 2010 \\
\hline RH_MLLW & Organic H. Solids & Boxes & Organic & 2011 \\
\hline RH_MLLW & Organic H. Solids & Boxes & Organic & 2012 \\
\hline RH_MLLW & Organic H. Solids & Boxes & Organic & 2013 \\
\hline
\end{tabular}

0.02 Organic destruction 0.001 Stabilization/Neutralization 0.001 Stabilization/Neutralization 0.001 Stabilization/Neutralization 0.003 Direct Disposal 0.003 Direct Disposal 0.003 Direct Disposal 0.04 Direct Disposal 0.003 Stabilization/Neutralization 0.003 Stabilization/Neutralization 0.003 Stabilization/Neutralization 0.003 Stabilization/Neutralization 0.003 Stabilization/Neutralization 0.003 Stabilization/Neutralization 0.003 Stabilization/Neutralization 0.003 Stabilization/Neutralization 0.003 Stabilization/Neutralization 0.003 Stabilization/Neutralization 0.003 Stabilization/Neutralization 0.003 Stabilization/Neutralization 0.003 Stabilization/Neutralization 0.003 Stabilization/Neutralization 0.003 Stabilization/Neutralization 0.003 Stabilization/Neutralization 0.004 StabilizationNeutralization 0.004 Stabilization Neutralization 0.004 Stabilization/Neutralization 0.004 Stabilization Neutralization 0.004 Stabilization Neutralization 0.003 Stabilization/Neutralization 0.003 Stabilization/Neutralization 0.003 Stabilization/Neutralization 0.003 Stabilization/Neutralization 0.003 Stabilization/Neutralization 0.003 Stabilization/Neutralization 0.003 Stabilization/Neutralization 0.003 Stabilization/Neutralization 0.003 Stabilization/Neutralization 0.003 Stabilization/Neutralization 0.003 Stabilization/Neutralization 0.003 Stabilization/Neutralization 0.003 Stabilization/Neutralization 0.001 Stabilization/Neutralization

0.3 Organic destruction

0.3 Organic destruction

0.3 Organic destruction

0.3 Organic destruction

0.3 Organic destruction

0.3 Organic destruction

0.3 Organic destruction

0.3 Organic destruction

0.3 Organic destruction

0.3 Organic destruction

0.3 Organic destruction

0.3 Organic destruction

0.3 Organic destruction

0.3 Organic destruction

0.3 Organic destruction

0.3 Organic destruction 


\begin{tabular}{|c|c|c|c|c|}
\hline RH_MLLW & Organic H. Solids & Boxes & Organic & 2014 \\
\hline RH_MLLW & Organic H. Solids & Boxes & Organic & 2015 \\
\hline RH_MLLW & Organic H. Solids & Boxes & Organic & 2016 \\
\hline RH_MLLW & Organic H. Solids & Boxes & Organic & 2017 \\
\hline RH_MLLW & Organic $H$. Solids & Boxes & Organic & 2018 \\
\hline RH_MLLW & - Organic H. Solids & Boxes & Organic & 2019 \\
\hline RH_MLLW & Organic H. Solids & Boxes & Organic & 2020 \\
\hline RH_MLLW & Organic H. Solids & Boxes & Organic & 2021 \\
\hline RH_MLLW & Organic H. Solids & Boxes & Organic & 2022 \\
\hline RH_MLLW & Organic $H$. Solids & Boxes & Organic & 2023 \\
\hline RH_MLLW & Organic $\mathrm{H}$. Solids & Boxes & Organic & 2024 \\
\hline RH_MLLW & Organic $H$. Solids & Boxes & Organic & 2025 \\
\hline RH_MLLW & Organic $H$. Solids & Boxes & Organic & 2026 \\
\hline RH_MLLW & Organic $H$. Solids & Boxes & Organic & 2027 \\
\hline RH_MLLW & Organic H. Solids & Boxes & Organic & 2028 \\
\hline RH_MLLW & Organic H. Solids & Boxes & Organic & 2029 \\
\hline RH_MLLW & Organic H. Solids & Boxes & Organic & 2030 \\
\hline RH_MLLW & Organic H. Solids & Boxes & Organic & 2031 \\
\hline RH_MLLW & Organic H. Solids & Boxes & Organic & 2032 \\
\hline RH_MLLW & Organic H. Solids & Drums & Corr+Met w/o Hg+OTg+WA State & 1998 \\
\hline RH_MLLW & Organic H. Soljds & Druns & Corr + Met w/o Hg+Org + WA State & 1999 \\
\hline RH_MLLW & Organic H. Solids & Drums & Corr + Met w/o Hg+Org +WA State & 2000 \\
\hline RH_MLLW & Organic H. Solids & Drums & Corr + Met w/o Hg + Org + WA State & 2001 \\
\hline RH_MLLW & Organic H. Solids & Drums & Corr + Met w/o $\mathrm{Hg}+\mathrm{Org}+$ WA State & 2002 \\
\hline RH_MLLW & Organic H. Solids & Drums & Corr + Met w/o Hg+Org+WA State & 2003 \\
\hline $\mathrm{RH} \_\mathrm{MLLW}$ & Organic H. Solids & Drums & Corr + Met w/o $\mathrm{Hg}+$ Org + WA State & 2004 \\
\hline RH_MLLW & Organic H. Solids & Drums & Corr + Met w/o Hg+Org + WA State & 2005 \\
\hline RH_MLLW & Organic H. Solids & Drums & Corr + Met w/o Hg+Org+WA State & 2006 \\
\hline RH_MLLW & Organic H. Solids & Drums & Corr + Met w/o Hg + Org + WA State & 2007 \\
\hline RH_MLLW & Organic H. Solids & Drums & $\mathrm{Corr}+\mathrm{Met} w / 0 \mathrm{Hg}+\mathrm{Org}+$ WA State & 2008 \\
\hline RH_MLLW & Organic H. Solids & Drums & Corr + Met w/o Hg + Org + WA State & 2009 \\
\hline RH_MLLW & Organic H. Solids & Drums & Corr + Met w/o Hg+Org+WA State & 2010 \\
\hline RH_MLLW & Organic H. Soljds & Drums & Corrosive & 1998 \\
\hline RH_MLLW & Organic H. Solids & Drums & Corrosive & 1999 \\
\hline RH_MLLW & Organic H. Solids & Drums & Corrosive & 2000 \\
\hline RH_MLLW & Organic H. Solids & Drums & Corrosive & 2001 \\
\hline RH_MLLW & Organic H. Solids & Drums & Corrosive & 2002 \\
\hline RH_MLLW & Organic H. Solids & Drums & Corrosive & 2003 \\
\hline RH_MLLW & Organic H. Solids & Drums & Corrosive & 2004 \\
\hline RH_MLLW & Organic H. Solids & Drums & Corrosive & 2005 \\
\hline RH_MLLW & Organic H. Solids & Drums & Corrosive & 2006 \\
\hline RH_MLLW & Organic H. Solids & Drums & Corrosive & 2007 \\
\hline RH_MLLW & Organic H. Solids & Drums & Corrosive & 2008 \\
\hline RH_MLLW & Organic H. Solids & Drums & Corrosive & 2009 \\
\hline RH_MLLW & Otganic H. Solids & Drums & Corrosive & 2010 \\
\hline RH_MLLW & Otganic H. Solids & Drums & Corrosive & 2011 \\
\hline RH_MLLW & Organic H. Solids & Drums & Corrosive & 2012 \\
\hline RH_MLLW & Otganic $H$. Solids & Drums & Corrosive & 2013 \\
\hline RH_MLLW & Organic H. Solids & Drums & Corrosive & 2014 \\
\hline RH_MLLW & Organic H. Solids & Drums & Corrosive & 2015 \\
\hline RH_MLLW & Organic H. Solids & Drums & Corrosive & 2016 \\
\hline RH_MLLW & Organic $H$. Solids & Drums & Corrosive & 2017 \\
\hline RH_MLLW & Organic $H$. Solids & Drums & Corrosive & 2018 \\
\hline RH_MLLW & Organic H. Solids & Drums & Corrosive & 2019 \\
\hline RH_MLLW & Organic H. Solids & Drums & Corrosive & 2020 \\
\hline RH_MLLW & Otganic H. Solids & Drums & Corrosive & 2021 \\
\hline RH_MLLW & Organic H. Solids & Drums & Corrosive & 2022 \\
\hline RH_MLLW & Otganic H. Solids & Drums & Corrosive & 2023 \\
\hline RH_MLLW & Organic H. Solids & Drums & Corrosive & 2024 \\
\hline
\end{tabular}

0.4 Organic destruction

0.4 Organic destruction

0.4 Organic destruction

0.4 Organic destruction

0.4 Organic destruction

0.3 Organic destruction

0.3 Organic destruction

0.3 Organic destruction

0.3 Organic destruction

0.3 Organic destruction

0.3 Organic destruction

0.3 Organic destruction

0.3 Organic destruction

0.3 Organic destruction

0.3 Organic destruction

0.3 Organic destruction

0.3 Organic destruction

0.3 Organic destruction

0.1 Organic destruction

2 Stabilization/Neutralization

2 Stabilization/Neutralization

2 Stsbilization/Neutralization

2 Stabilization/Neutralization

2 Stsbilization/Neutralization

2 Stabilization/Neutralization

2 Stsbilization/Neutralization

2 Stabilization/Neutralization

2 Stabilization/Neutralization

2 Stabilization/Neutralization

2 Stabilization/Neutralization

2 Stabilization/Neutralization

2 Stabilization/Neutralization

0.3 Stabilization/Neutralization

0.3 Stabilization/Neutralization

0.2 Stabilization/Neutralization

0.2 Stabilization/Neutralization

0.2 Stabilization/Neutralization

0.2 Stabilization/Neutralization

0.2 Stabilization Neutralization

0.2 Stabilization/Neutralization

0.2 Stabilization/Neutralization

0.2 Stabilization/Neutralization

0.2 Stabilization Neutralization

0.2 Stabilization/Neutralization

0.2 Stabilization/Neutralization

0.2 Stabilization/Neutralization

0.2 Stabilization/Neutralization

0.2 Stabilization/Neutralization

0.2 Stabilization/Neutralization

0.2 Stabilization/Neutralization

0.2 Stabilization/Neutralization

0.2 Stabilization/Neutralization

0.2 Stabilization/Neutralization

0.2 Stabilization/Neutralization

0.2 Stabilization/Neutralization

0.2 Stabilization/Netutralization

0.2 Stabilization/Neutralization

0.2 Stabilization/Neutralization

0.2 Stabilization Neutralization 


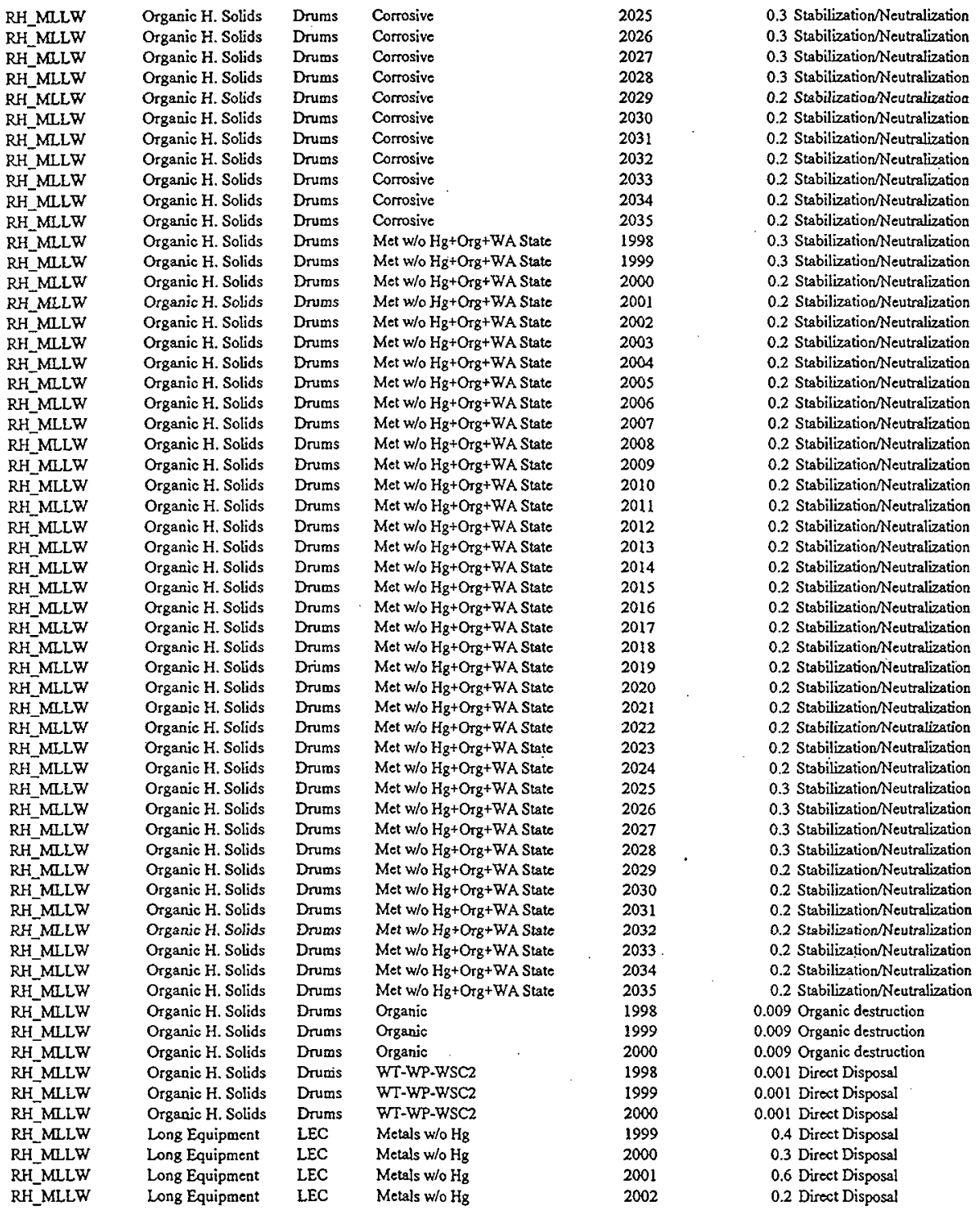




\begin{tabular}{|c|c|c|c|c|}
\hline RH_MLLW & Long Equipment & LEC & Metals w/o Hg & 2003 \\
\hline RH_MLLW & Long Equipment & LEC & Metals w/o Hg & 2004 \\
\hline RH_MLLW & Long Equipment & LEC & Metals w/o Hg & 2005 \\
\hline RH_MLLW & Long Equipment & LEC & Metals w/o Hg & 2009 \\
\hline RH_MLLW & Long Equipment & LEC & Metals w/o $\mathrm{Hg}$ & 2010 \\
\hline RH_MLLW & Long Equipment & LEC & Metals w/o Hg & 2011 \\
\hline RH_MLLW & Long Equipment & LEC & Metals w/o Hg & 2012 \\
\hline RH_MLLW & Long Equipment & LEC & Metals w/o Hg & 2013 \\
\hline RH_MLLW & Long Equipment & LEC & Metals w/o $\mathrm{Hg}$ & 2014 \\
\hline RH_MLLW & Long Equipment & LEC & Metals w/o Hg & 2015 \\
\hline RH_MLLW & Long Equipment & LEC & Metals w/o $\mathrm{Hg}$ & 2016 \\
\hline RH_MLLW & Long Equipment & LEC & Metals w/o $\mathrm{Hg}$ & 2017 \\
\hline RH_MLLW & Long Equipment & LEC & Metals w/o $\mathrm{Hg}_{\mathrm{g}}$ & 2018 \\
\hline RH_MLLW & Long Equipmeat & LEC & Metals w/o Hz & 2019 \\
\hline RH_MLLW & Long Equipment & LEC & Metals w/o $\mathrm{Hg}$ & 2020 \\
\hline RH_MLLW & Long Equipment & LEC & Metals w/o Hg & 2021 \\
\hline RH_MLLW & Long Equipment & LEC & Metals w/o Hg & 2022 \\
\hline RH_MLLW & Long Equipment & LEC & Metals w/o Hg & 2023 \\
\hline RH_MLLW & Long Equipment & LEC & Metals w/o Hg & 2024 \\
\hline RH_MLLW & Long Equipment & LEC & Metals w/o $\mathrm{Hg}$ & 2025 \\
\hline RH_MLLW & Long Equipment & LEC & Metals w/o Hg & 2026 \\
\hline RH_MLLW & Long Equipment & LEC & Metals w/o Hg & 2027 \\
\hline RH_MLLW & Long Equipment & LEC & Metals w/o $\mathrm{Hg}$ & 2028 \\
\hline RH_MLLW & Long Equipment & LEC & Organic & 1999 \\
\hline RH_MLLW & Long Equipmeat & LEC & Organic & 2000 \\
\hline RH_MLLW & Long Equipment & LEC & Organic & 2001 \\
\hline RH_MLLW & Long Equipment & LEC & Organic & 2002 \\
\hline RH_MLLW & Long Equipment & LEC & Organic & 2003 \\
\hline RH_MLLW. & Long Equipment & LEC & Organic & 2004 \\
\hline RH_MLLW & Long Equipment & LEC & Organic & 2005 \\
\hline RH_MLLW & Long Equipment & LEC & Organic & 2009 \\
\hline RH_MLLW & Long Equipment & LEC & Organic & 2010 \\
\hline RH_MLLW & Long Equipment & LEC & Organic & 2011 \\
\hline RH_MLLW & Long Equipment & LEC & Organic & 2012 \\
\hline RH_MLLW & Long Equipment & LEC & Organic & 2013 \\
\hline RH_MLLW & Long Equipment & LEC & Organic & 2014 \\
\hline RH_MLLW & Long Equipment & LEC & Organic & 2015 \\
\hline RH_MLLW & Long Equipment & LEC & Organic & 2016 \\
\hline RH_MLLW & Long Equipment & LEC & Organic & 2017 \\
\hline RH_MLLW & Long Equipment & LEC & Organic & 2018 \\
\hline RH_MLLW & Long Equipment & LEC & Organic & 2019 \\
\hline RH_MLLW & Long Equipment & LEC & Organic & 2020 \\
\hline RH_MLLW & Long Equipment & LEC & Organic & 2021 \\
\hline RH_MLLW & Long Equipment & LEC & Organic & 2022 \\
\hline RH_MLLW & Long Equipment & LEC & Organic & 2023 \\
\hline RH_MLLW & Long Equipment & LEC & Organic & 2024 \\
\hline RH_MLLW & Long Equipment & LEC & Organic & 2025 \\
\hline RH_MLLW & Long Equipment & LEC & Organic & 2026 \\
\hline RH_MLLW & Long Equipment & LEC & Organic & 2027 \\
\hline RH_MLLW & Long Equipment & LEC & Organic & 2028 \\
\hline RH_MLLW & Soil/Gravel & Drums & Corrosive & 1998 \\
\hline RH_MLLW & Soil/Gravel & Drums & Corrosive & 1999 \\
\hline RH_MLLW & SoivGravel & Drums & Corrosive & 2000 \\
\hline RH_MLLW & Soil/Gravel & Drums & Metals w/o Hg & 1998 \\
\hline RH_MLLW & Soil/Gravel & Drums & Metals w/o Hg & 1999 \\
\hline RH_MLLW & Soil/Gravel & Drums & Metals w/o Hg & 2000 \\
\hline RH_MLLW & Soil/Gravel & Drums & Metals w/o $\mathrm{H}_{\mathrm{B}}$ & 2001 \\
\hline RH_MLLW & SoilfGravel & Drums & Metals w/o Hg & 2002 \\
\hline RH_MLLW & Soil/Gravel & Drums & Metals w/o Hg & 2003 \\
\hline
\end{tabular}

0.1 Direct Disposal

0.5 Direct Disposal

0.1 Direct Disposal

0.1 Direct Disposal

0.1 Direct Disposal

0.7 Direct Disposal

0.8 Direct Disposal

0.8 Direct Disposal

0.8 Direct Disposal

0.8 Diroet Disposal

0.8 Direct Disposal

0.8 Direct Disposal

0.8 Direct Disposal

1.0 Direct Disposal

1.0 Direct Disposal

1 Direct Disposal

0.5 Direct Disposal

0.5 Direct Disposal

0.5 Direct Disposal

0.5 Direct Disposal

0.5 Direct Disposal

0.5 Direct Disposal

0.5 Direct Disposal

4 Direct Disposal

2 Direct Disposal

5 Direct Disposal

2 Direct Disposal

1 Direct Disposal

4 Direct Disposal

1 Direct Disposal

1 Direct Disposal

1 Direct Disposal

6 Direct Disposal

7 Direct Disposal

7 Direct Disposal

7 Direct Disposal

7 Direct Disposal

7 Direct Disposal

7 Direct Disposal

7 Direct Disposal

9 Direct Disposal

9 Direct Disposal

10 Direct Disposal

4 Direct Disposel

4 Direet Disposal

4 Direct Disposal

4 Direct Disposal

4 Direct Disposal

4 Direct Disposal

4 Direct Disposal

0.005 Stabilization/Neutralization 0.005 Stabilization/Neutralization 0.005 Stabilization/Neutralization

0.02 Stabilization/Neutralization 0.06 Stabilization/Neutralization

0.2 Stabilization/Neutralization

0.1 Stabilization/Neutralization

0.1 Stabilization/Neutralization

0.1 Stabilization/Neutralization 


$\begin{array}{lllll}\text { RH_MLLW } & \text { SoiVGravel } & \text { Drums } & \text { Metals w/o Hg } & 2004 \\ \text { RH_MLLW } & \text { SoiVGravel } & \text { Drums } & \text { Metals w/o Hg } & 2005 \\ \text { RH_MLLW } & \text { SoiVGravel } & \text { Drums } & \text { Organic } & 1998 \\ \text { RH_MLLW } & \text { SoiVGravel } & \text { Drums } & \text { Organic } & 1999 \\ \text { RH_MLLW } & \text { SoiVGravel } & \text { Drums } & \text { Organic } & 2000 \\ \text { RH_MLLW } & \text { Soil/Gravel } & \text { Drums } & \text { Organic } & 2001 \\ \text { RH_MLLW } & \text { Soil/Gravel } & \text { Drums } & \text { Organic } & 2002 \\ \text { RH_MLLW } & \text { Soil/Gravel } & \text { Drums } & \text { Organic } & 2003 \\ \text { RH_MLLW } & \text { Soil/Gravel } & \text { Drums } & \text { Organic } & 2004 \\ \text { RH_MLLW } & \text { Soil/Gravel } & \text { Drums } & \text { Organic } & 2005 \\ \text { RH_MLLW } & \text { Soil/Gravel } & \text { Drums } & \text { Wr-WP-WSC2 } & 1998 \\ \text { RH_MLLW } & \text { SoiVGravel } & \text { Drums } & \text { WT-WP-WSC2 } & 1999 \\ \text { RH_MLLW } & \text { Soil/Gravel } & \text { Drums } & \text { WT-WP-WSC2 } & 2000 \\ \text { RH_MLLW } & \text { Special Wastes } & \text { Drums } & \text { Cort+Met w/o Hg } & 2004 \\ \text { RH_MLLW } & \text { Special Wastes } & \text { Drums } & \text { Corrosive } & 1998 \\ \text { RH_MLLW } & \text { Special Wastes } & \text { Drums } & \text { Corrosive } & 1999 \\ \text { RH_MLLW } & \text { Special Wastes } & \text { Drums } & \text { Corrosive } & 2000 \\ \text { RH_MLLW } & \text { Special Wastes } & \text { Drums } & \text { Corrosive } & 2004 \\ \text { RH_MLLW } & \text { Special Wastes } & \text { Drums } & \text { Metals w/Hg } & 1998 \\ \text { RH_MLLW } & \text { Special Wastes } & \text { Drums } & \text { Metals w/ Hg } & 1999 \\ \text { RH_MLLW } & \text { Special Wastes } & \text { Drums } & \text { Metals w/ Hg } & 2000 \\ \text { RH_MLLW } & \text { Special Wastes } & \text { Drums } & \text { Metals w/o Hg } & 1998 \\ \text { RH_MLLW } & \text { Special Wastes } & \text { Drums } & \text { Metals w/o Hg } & 1999 \\ \text { RH_MLLW } & \text { Special Wastes } & \text { Drums } & \text { Metals w/o Hg } & 2000 \\ \text { RH_MLLW } & \text { Special Wastes } & \text { Drums } & \text { Metals w/o Hg } & 2004 \\ \text { RH_MLLW } & \text { Special Wastes } & \text { Drums } & \text { Wr-WP-WSC2 } & 2004 \\ & & & & \end{array}$

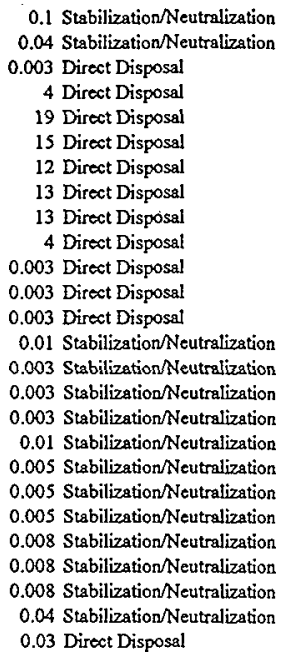

0.1 Stabilization/Neutralization

003 Direct Disposal

4 Direct Disposal

19 Direct Disposal

15 Direct Disposal

12 Direct Disposal

13 Direct Disposal

13 Direct Disposal

4 Direct Disposal

0.003 Direct Disposal

0.003 Direct Disposal

0.003 Direct Disposal

0.01 Stabilization/Neutralization 0.003 Stabilization/Neutralization 0.003 Stabilization/Neutralization 0.003 Stabilization/Neutralization 0.01 Stabilization/Neutralization 0.005 Stabilization/Neutralization 0.005 Stabilization/Neutralization 0.005 Stabilization/Neutralization 0.008 Stabilization/Neutralization 0.008 Stabilization/Neutralization 0.04 Stabilization/Neutralization 0.03 Direct Disposal 
HNF-4293

APPENDIX C 
This page intentionally left blank. 


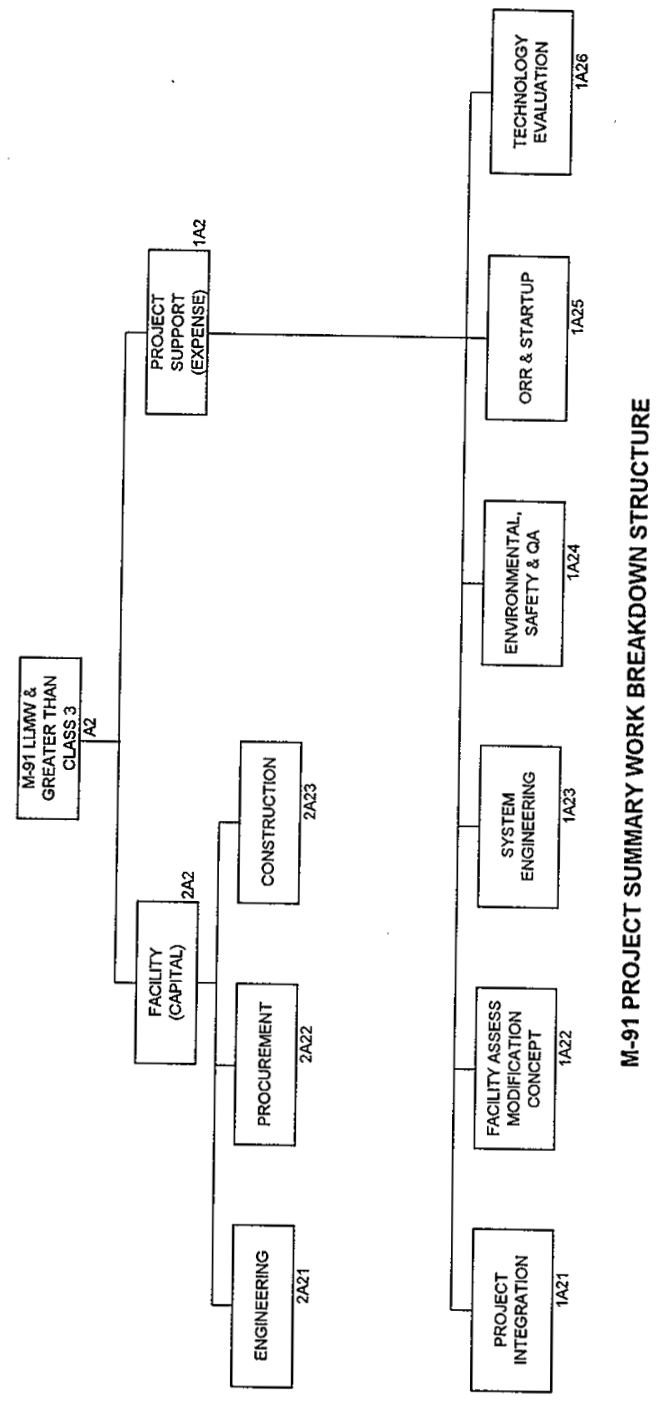




\section{PROJECT SUMMARY WORK BREAKDOWN STRUCTURE DICTIONARY ELEMENT DEFINITION}

1. Project Title: M-91 LLMW \& Greater than Class 3

3. Identification Number:

5. WBS Element Title: M-91 LLMW \& Greater than Class 3

7. Approved Changes:

8. System Description:

9. Budget and Reporting Number:
2. Date: January 18, 1999

4. WBS Element Code: A2

6. Index Line No:

10. Element Task Description:

a) Cost Content: Engineering \& Design

Labor

Procurement

Travel

Project Management

Other Hanford Contractor Services:

Document Control

Subcontract Efforts

Offsite Architect-Engineer

Reproduction

Fixed-Price Construction Contractor

Computer Services

Overhead

b) Technical Content: Engineering and Design

Improvement to Land

Buildings

Utilities

Special Equipment/Process Systems

Office Furniture/Equipment

Shop Equipment

c) Work Statement: The M-91 LLMW Greater than Class 3 facilities will receive, sort, process, repackage, and load CH LLMW and Macro-encapsulate and load RH LLMW for shipment to disposal. As the highest level WBS element, all of the project work is included in this element. 


\section{PROJECT SUMMARY WORK BREAKDOWN STRUCTURE DICTIONARY ELEMENT DEFINITION}

1. Project Title: M-91 LLMW \& Greater than Class 3

3. Identification Number:

5. WBS Element Title: Facility

7. Approved Changes:

8. System Description:

9. Budget and Reporting Number:
2. Date: January 18,1999

4. WBS Element Code: $2 \mathrm{~A} 2$

6. Index Line No:

10. Element Task Description:

a) Cost Content: Labor
A/E Services
Travel
Construction Contractor
Other Hanford Contractor Services:
Construction Management and Administration
Procurement

b) Technical Content: Provide design. Perform site facility construction and provide construction management services. Procure equipment

c) Work Statement: Perform design of the M-91 facilities modifications, including all drawings, specifications and test procedures for utilities and equipment. Provide construction management services and modify the M-91 facilities in accordance with the detailed design and perform testing to verify that the construction and equipment conform to design requirements. Prepare procurement documents for and procure the equipment 


\section{PROJECT SUMMARY WORK BREAKDOWN STRUCTURE DICTIONARY ELEMENT DEFINITION}

1. Project Title: M-91 LLMW \& Greater than Class 3

3. Identification Number:

5. WBS Element Title: Engineering

7. Approved Changes:

8. System Description:

1. Budget and Reporting Number:
2. Date: January 18,1999

4. WBS Element Code: $2 \mathrm{~A} 21$

6. Index Line No:

2. Element Task Description:

a) Cost Content: $\mathrm{A} / \mathrm{E}$ Contract

b) Technical Content: Provide design of the M-91 LLMW Greater than Class 3. Provide Construction Engineering and Inspection.

c) Work Statement: Provide design for the M-91 LLMW Greater than Class facilities modifications, including utilities and equipment. This includes preparation of drawings, specifications, and test procedures. Provide field engineering and inspection services during the construction phase. 


\section{PROJECT SUMMARY WORK BREAKDOWN STRUCTURE DICTIONARY \\ ELEMENT DEFINITION}

1. Project Title: M-91 LLMW \& Greater than Class 3

3. Identification Number:

5. WBS Element Title: Procurement

7. Approved Changes:

8. System Description:

1. Budget and Reporting Number:
2. Date: January 18, 1999

4. WBS Element Code: $2 \mathrm{~A} 22$

6. Index Line No:

2. Element Task Description:

a) Cost Content: Equipment

b) Technical Content: Procure equipment in accordance with applicable drawings and specifications.

c) Work Statement: Prepare procurement documents and bid packages, evaluate the bids, award the contracts, administer the contracts and provide for warehousing and maintenance of the procured equipment. 


\section{PROJECT SUMMARY WORK BREAKDOWN STRUCTURE DICTIONARY ELEMENT DEFINITION}

1. Project Title: M-91 LLMW \& Greater than Class 3

3. Identification Number:

5. WBS Element Title: Construction

7. Approved Changes:

8. System Description:

1. Budget and Reporting Number:
2. Date: January 18,1999

4. WBS Element Code: $2 \mathrm{~A} 23$

6. Index Line No

2. Element Task Description:

a) Cost Content: Construction Contractor

b) Technical Content: Perform facility modifications and testing in accordance with approved design media.

c) Work Statement: Modify an existing facility for the M-91 LLMW including all utilities and equipment. Perform test procedures to verify that construction and equipment conform to the design media. 


\section{PROJECT SUMMARY WORK BREAKDOWN STRUCTURE DICTIONARY ELEMENT DEFINITION}

1. Project Title: M-91 LLMW \& Greater than Class 3

3. Identification Number:

5. WBS Element Title: Project Support

7. Approved Changes:

8. System Description:

9. Budget and Reporting Number:
2. Date: January 18, 1999

4. WBS Element Code: 1A2

6. Index Line No:

10. Element Task Description:

a) Cost Content: Labor

Miscellaneous Services

Travel

P O Contract

Computers

Office Supplies

Duplicating

b) Technical Content: Provide project integration, systems engineering, operations preparedness and startup, conceptual development, technology evaluation, and environmental, safety and $Q A$ support for the M-91 LLMW \&Greater than Class 3 project.

c) Work Statement: Integrate the work of all project participants and provide data management for the project. Provide engineering support for process definition and. Develop procedures and specifications for plant startup and operation. Develop project scope, cost estimate, schedule and design parameters. Evaluate and select process to be used for the project. Prepare the project safety related reports and oversee the project QA requirements. 


\section{PROJECT SUMMARY WORK BREAKDOWN STRUCTURE DICTIONARY ELEMENT DEFINITION}

1. Project Title: M-91 LLMW \& Greater than Class 3

3. Identification Number:

5. WBS Element Title: Project Integration

7. Approved Changes:

8. System Description:

1. Budget and Reporting Number:
2. Date: January 18,1999

4. WBS Element Code: $1 A 21$

6. Index Line No:

2. Element Task Description:

a) Cost Content:

Labor

Travel

Miscellaneous Services

Commercial Interface

Office supplies

Duplicating

Microfilming

b) Technical Content: Provide project management and control during construction and startup at the M-91 facilities. Provide contractual support for commercial interface. Provide document control and engineering support for the project.

c) Work Statement: Integrate the interfacing of all project participants including scheduling, budgeting, performance measurement, baseline charge control administration and project plans and procedures. Administer project data management activities and provide engineering support for the SOW's safety documentation and reviews. Provide contractual support for the placement of commercial contracts. 


\section{PROJECT SUMMARY WORK BREAKDOWN STRUCTURE DICTIONARY \\ ELEMENT DEFINITION}

1. Project Title: M-91 LLMW \& Greater than Class 3

3. Identification Number:

5. WBS Element Titie: Facility Assessment Modification Concept

7. Approved Changes:

8. System Description:

1. Budget and Reporting Number:
2. Date: January 18, 1999

4. WBS Element Code: IA22

6. Index Line No:

2. Element Task Description:

a) Cost Content: Labor

AE Contract

b) Technical Content: Perform a proof of concept design of the M-91 LLMW Greater than Class 3

c) Work Statement: Develop a project scope, assure project feasibility and attainable performance levels, and develop a project cost estimate, schedules, and design parameters. Identify modifications required in selected facility to develop project baselines. 


\section{PROJECT SUMMARY WORK BREAKDOWN STRUCTURE DICTIONARY ELEMENT DEFINITION}

1. Project Title: M-91 LLMW \& Greater than Class 3.

3. Identification Number:

5. WBS Element Title: System Engineering

7. Approved Changes:

8. System Description:

9. Budget and Reporting Number:
2. Date: January 18, 1999

4. WBS Element Code: 1 A23

6. Index Line No

10. Element Task Description:

a) Cost Content: Labor

Material

Travel

P O Contract

Other Hanford Contractor Services

b) Technical Content: Provide the M-91 LLMW \& Greater than Class 3 waste disposal plan and definition.

c) Work Statement: Support flow sheet and functional design criteria/engineering study preparation, and support all plant process system interfacing requirements. Prepare operations start-up documents. 


\section{PROJECT SUMMARY WORK BREAKDOWN STRUCTURE DICTIONARY ELEMENT DEFINITION}

1. Project Title: M-91 LLMW \& Greater than Class 3

3. Identification Number:

5. WBS Element Title: Environmental, Safety \& QA

7. Approved Changes:

8. System Description:

1. Budget and Reporting Number:
2. Date: January 18, 1999

4. WBS Element Code: 1 A24

6. Index Line No:

2. Element Task Description:

a) Cost Content: Labor

Travel

Consultant Services

b) Technical Content: Provide environmental, safety and QA technical support to the M-91 project.

c) Work Statement: Prepare the revision to existing safety basis. Oversee project QA safety and requirement. 


\section{PROJECT SUMMARY WORK BREAKDOWN STRUCTURE DICTIONARY ELEMENT DEFINITION}

1. Project Title: M-91 LLMW \& Greater than Class 3

3. Identification Number:

5. WBS Element Title: Operational Readiness Review and Startup

7. Approved Changes:

8. System Description:

9. Budget and Reporting Number:
2. Date: October 12,1998

4. WBS Element Code: $1 \mathrm{~A} 25$

6. Index Line No:

10. Element Task Description:

a) Cost Content: Labor

Material
Travel
PO Contract
Overhead

b) Technical Content: Provide operational and startup planning including staffing and training. Provide operability and maintainability input to design and construction.

c) Work Statement: Review and monitor activities to assure designs meet programmatic/operational needs. Begin planning for operational startup including training preparations, OTP planning and operating procedure planning. 


\section{PROJECT SUMMARY WORK BREAKDOWN STRUCTURE DICTIONARY ELEMENT DEFINITION}

1. Project Title: M-91 LLMW \& Greater than Class 3

3. Identification Number:

5. WBS Element Title: Technology Evaluation

7. Approved Changes:

8. System Description:

1. Budget and Reporting Number:
2. Date: January 18, 1999

4. WBS Element Code: 1 A26

6. Index Line No:

2. Element Task Description:

a) Cost Content: Labor Material

Trave!

P O Contracts

b) Technical Content: Plan the M-91 LLMW equipment evaluation and provide technical direction to interface with the $\mathrm{A} / \mathrm{E}$ for mechanical equipment systems.

c) Work Statement: Evaluate vendor demonstrations for applicability to waste stream. Select technology for macro-encapsulation. 
HNF-4293

APPENDIX D

COST 
HNF-4293

2

3

4

This page intentionally left blank. 


\begin{tabular}{|c|c|c|c|c|}
\hline \multicolumn{5}{|c|}{ M-91-15 LLMW Facility Project: Total Project Cost } \\
\hline & FY 2003 & FY 2004 & FY 2005 & Total \\
\hline 1A2 Project Support & $\$ 220$ & $\$ 120$ & $\$ 180$ & $\$ 520$ \\
\hline 2A2 Facility (Capital) & $\$ 0$ & $\$ 480$ & $\$ 100$ & $\$ 580$ \\
\hline Total T-Plant Modification & $\$ 220$ & $\$ 600$ & $\$ 280$ & $\$ 1,100$ \\
\hline T-Plant Full Operations & $\$ 0$ & $\$ 0$ & $\$ 2,800$ & $\$ 2,800$ \\
\hline Total Project Cost & $\$ 220$ & $\$ 600$ & $\$ 3,080$ & $\$ 3,900$ \\
\hline
\end{tabular}




\begin{tabular}{|c|c|c|c|c|}
\hline \multicolumn{5}{|c|}{ M-91-15 LLMW Facility Project: } \\
\hline 1A2 Project Support & FY 2003 & FY 2004 & FY 2005 & Total \\
\hline 1A21 Project Integration & $\$ 60$ & $\$ 40$ & $\$ 20$ & $\$ 120$ \\
\hline $\begin{array}{l}1 \text { A22 T-Plant Modification } \\
\text { Assessment }\end{array}$ & $\$ 40$ & $\$ 0$ & $\$ 0$ & $\$ 40$ \\
\hline 1A23 System Engineering & $\$ 20$ & $\$ 10$ & $\$ 20$ & $\$ 50$ \\
\hline 1A24 Environmental Safety \& QA & $\$ 60$ & $\$ 20$ & $\$ 20$ & $\$ 100$ \\
\hline 1A25 ORR \& Startup & $\$ 0$ & $\$ 30$ & $\$ 120$ & $\$ 150$ \\
\hline 1A26 Technology Evaluation & $\$ 40$ & $\$ 20$ & $\$ 0$ & $\$ 60$ \\
\hline Total & $\$ 220$ & $\$ 120$ & $\$ 180$ & $\$ 520$ \\
\hline
\end{tabular}




\begin{tabular}{|c|c|c|c|}
\hline \multicolumn{4}{|c|}{ M-91-15 LLMW Facility Project: Capital Cost Resource Plan } \\
$(\$ 1,000)$
\end{tabular}



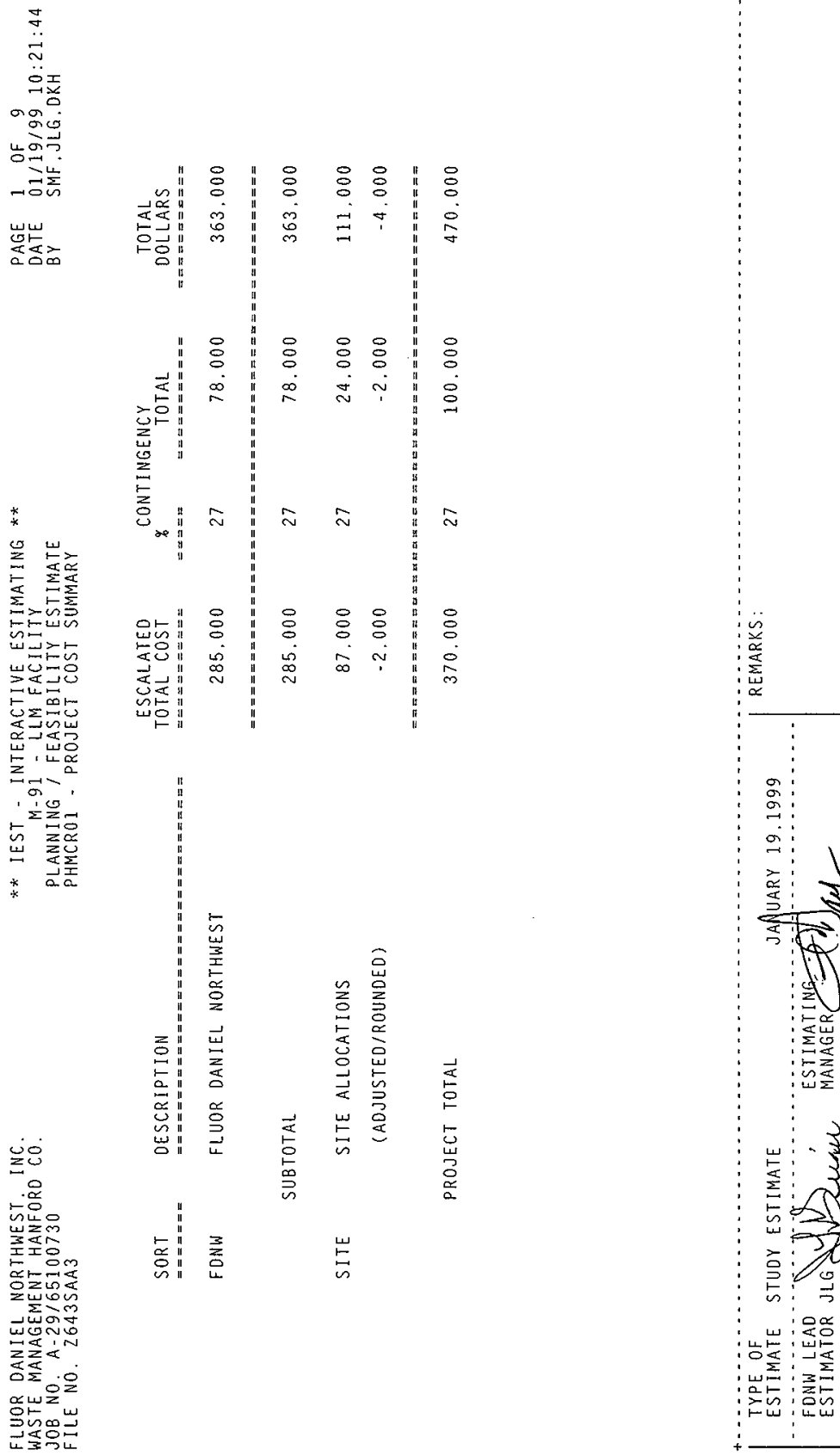


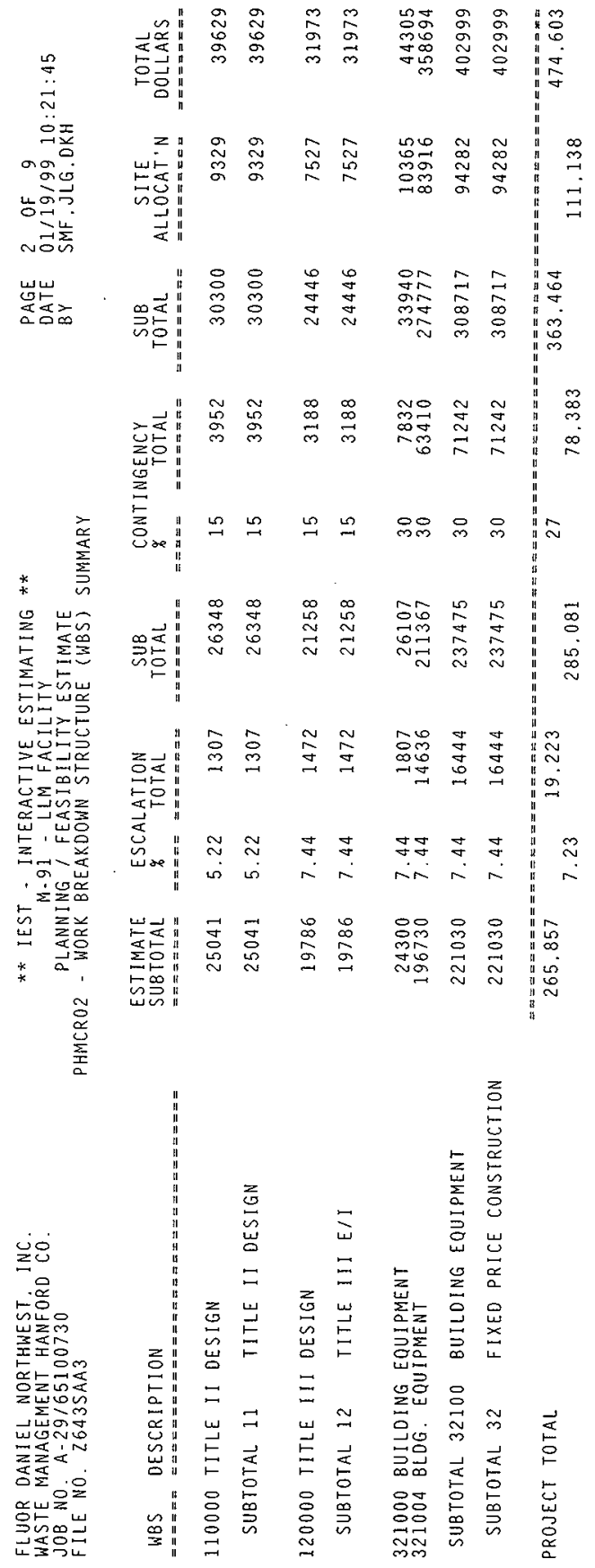




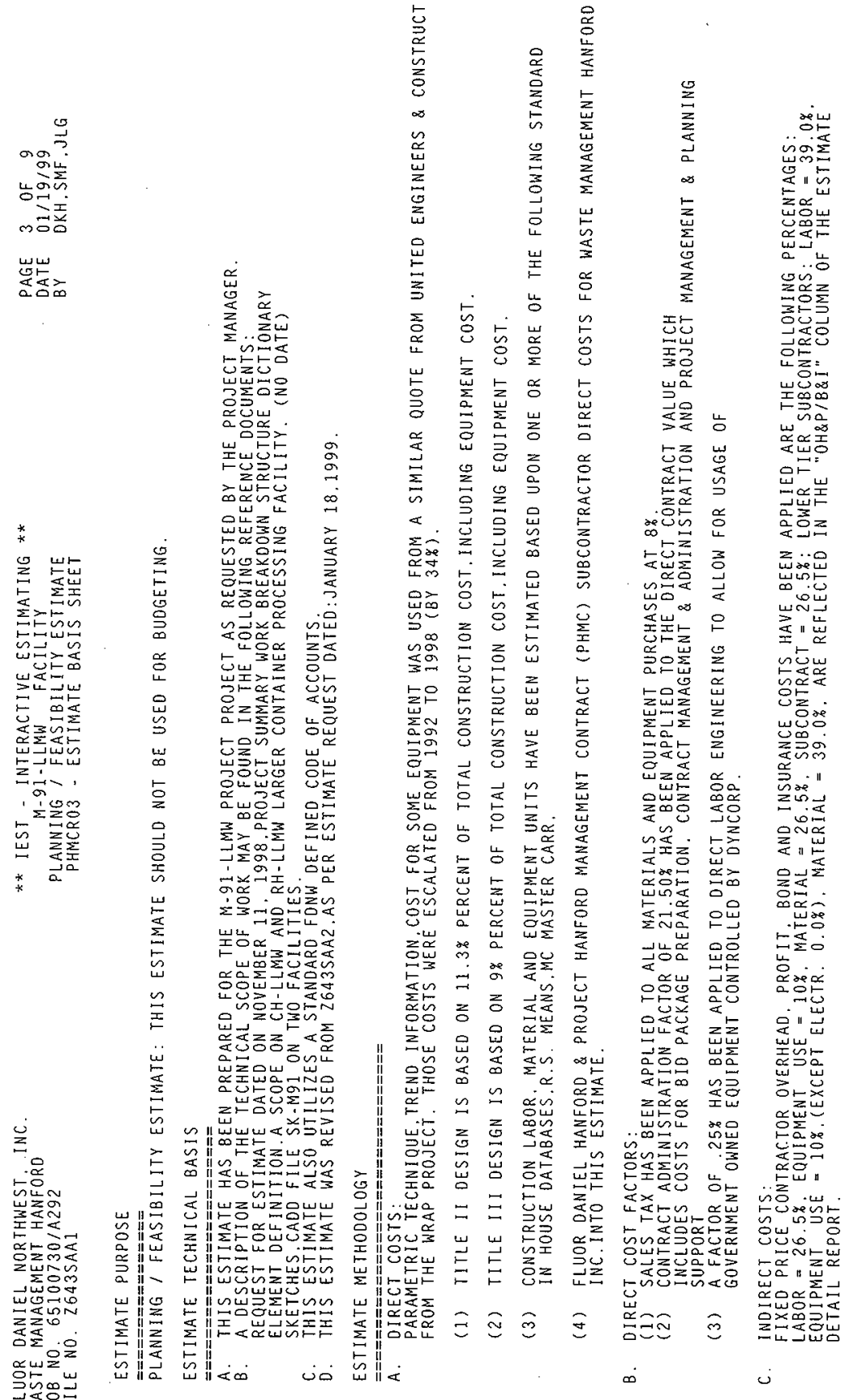




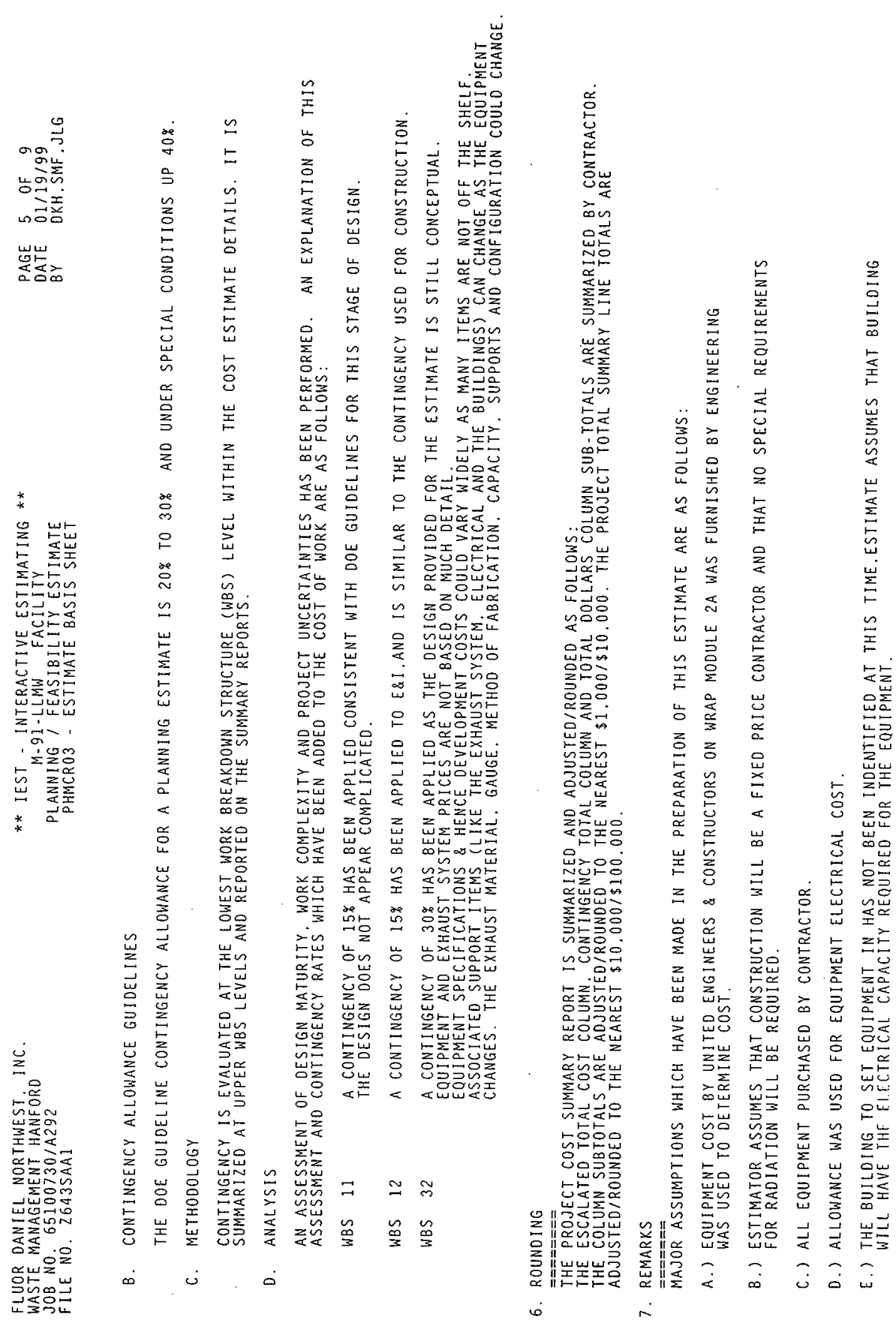




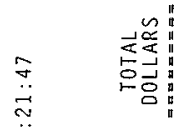

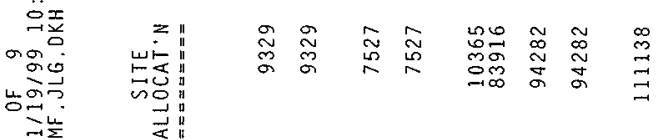

10i

ज崖这

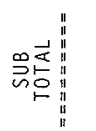

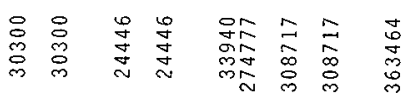

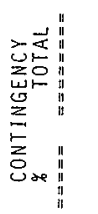

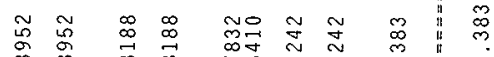

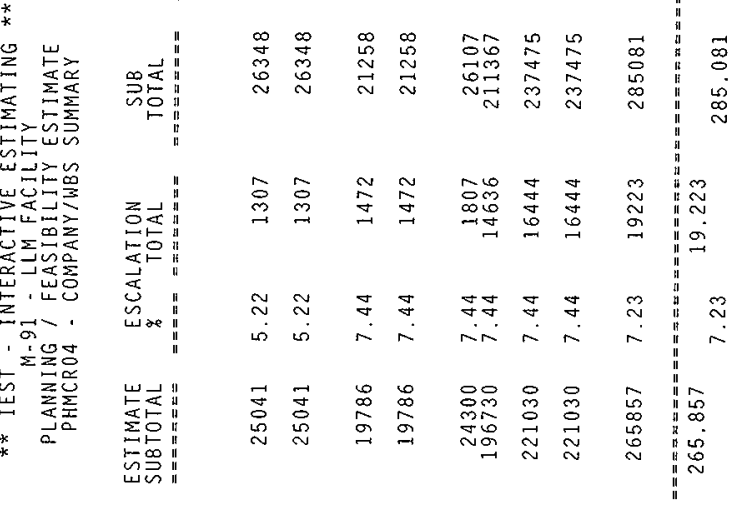

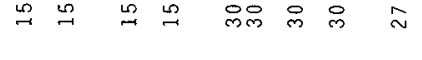

$\stackrel{*}{*}$

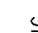

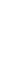




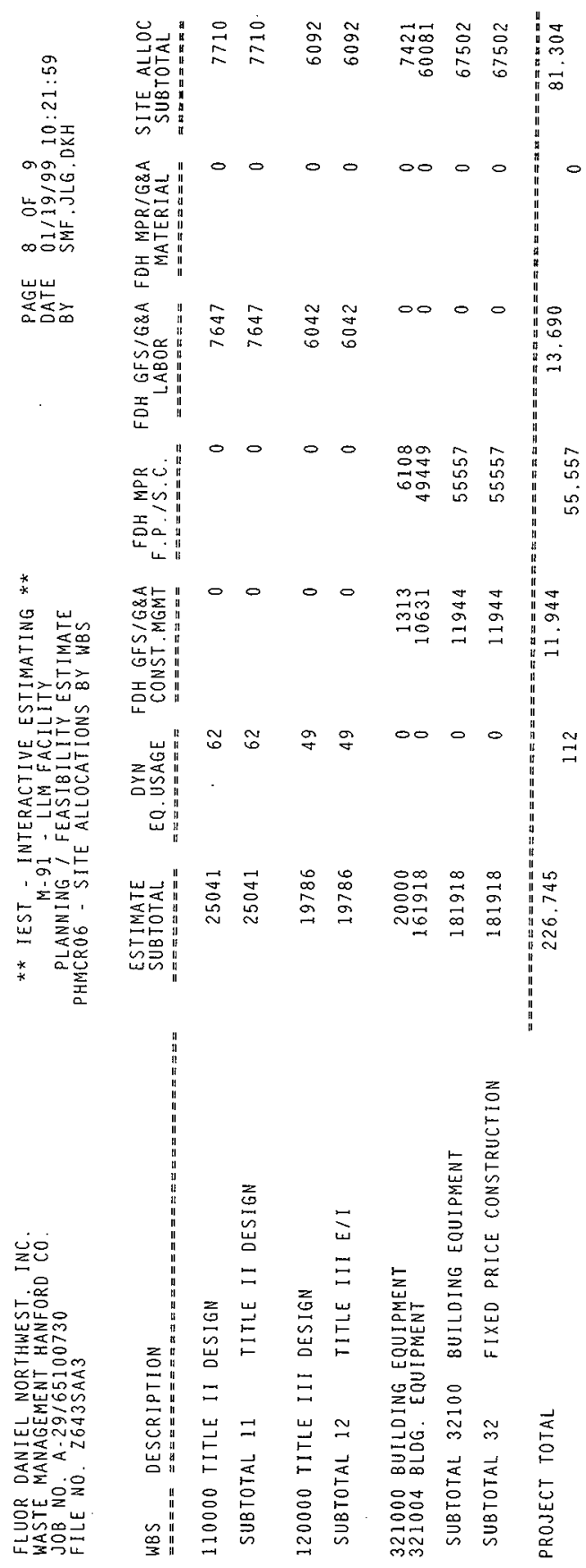


$\stackrel{\vec{n}}{a}$

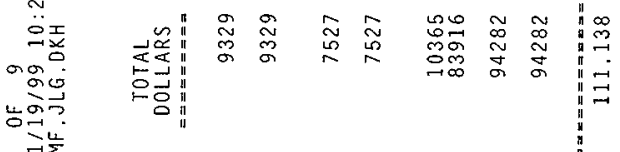

ตํํำ

㟧

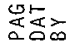

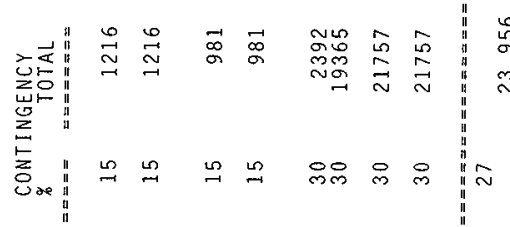

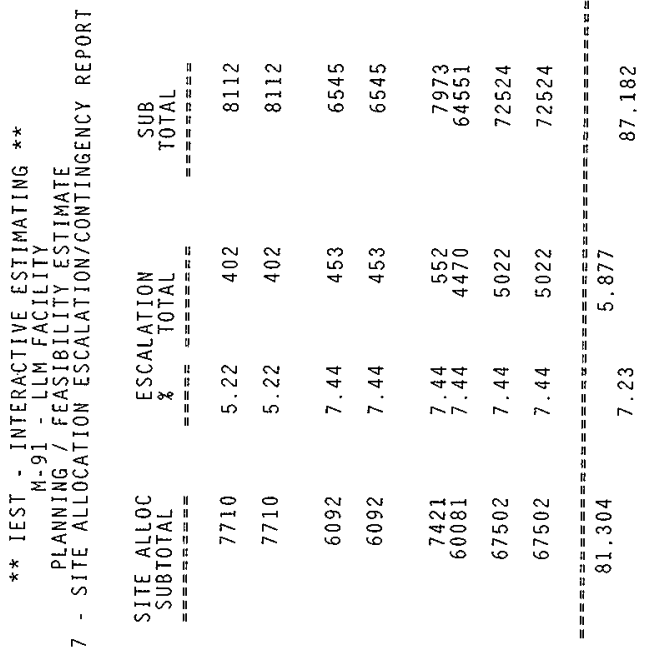

\section{نं}

용

눙요

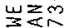

로종

낭

옹는

₹wom

- यका

แอก

Z象

吉发

ㄸㄹㄹ

号出出

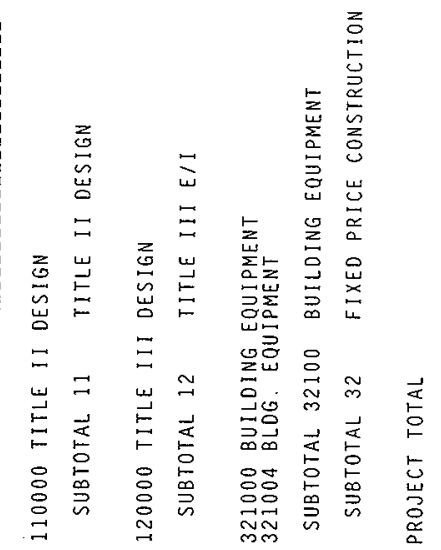




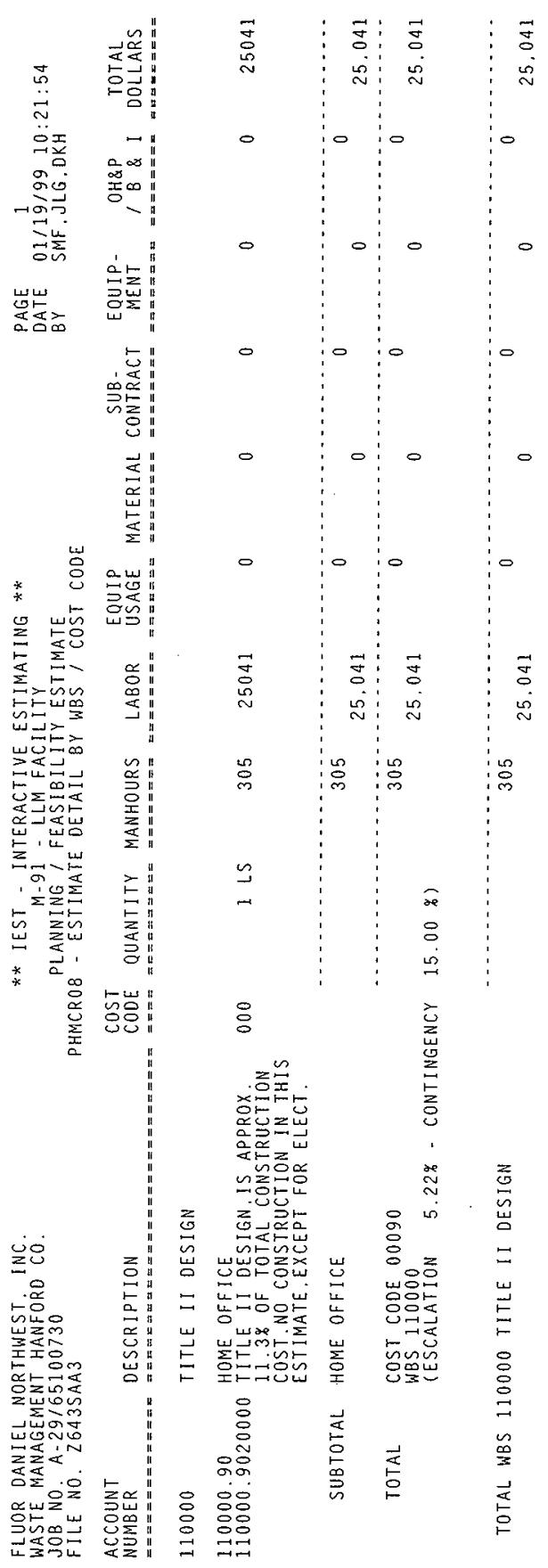




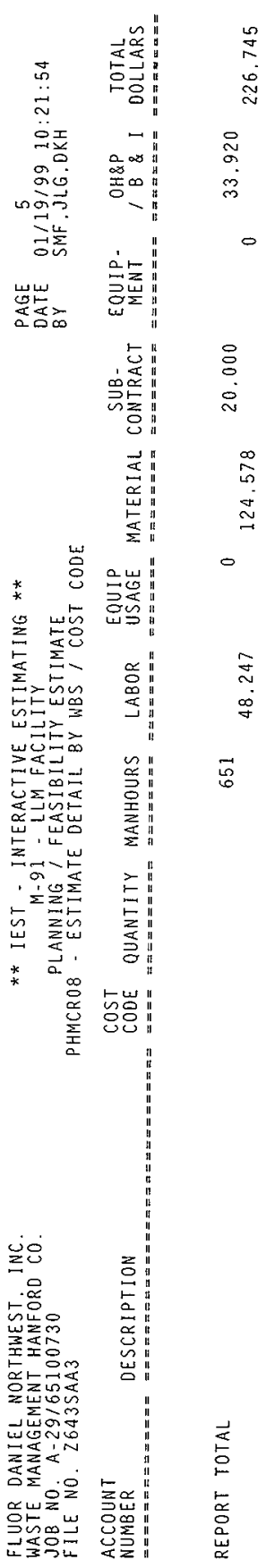




\section{DISTRRBUTON}

MSIN

\section{U. S. Department of Energy, Richland Operations Office}

E. M. Bowers

S7-55

R. F. Guercia

S7-55

K. R. Westover

S7-55

Fluor Daniel Hanford, Inc.

J. C. Renner

B3-70

K. J. Svoboda

H6-06

Lockheed Martin Services, Inc.

Central Files

B1-07

DPC

H6-08

Waste Management Federal Services of Hanford, Inc.

L.T. Blackford

T4-05

L. Bounini

H6-06

J. B, Buckley

T3-04

T. L. Moore

H6-30

K. M. Quigley

H6-06

L. F. Willis

H6-30

Distr -1 